Федеральная служба по надзору в сфере защиты прав потребителей и благополучия человека (Роспотребнадзор)

Федеральное бюджетное учреждение науки «Федеральный научный центр медико-профилактических технологий управления рисками здоровью населения»

\section{Адрес редакции: \\ 614045, Россия, Пермский край, г. Пермь, ул. Монастырская (Орджоникидзе), 82 \\ Тел.: 8 (342) 237-25-34 \\ E-mail: journal@fcrisk.ru \\ Сайт: http://fcrisk.ru/ \\ Редактор и корректор - Е.М. Сторожева Технический редактор - Е.Н. Несевря Переводчик - Е.А. Марсова}

Все права защищены. Ни одна часть этого издания не может быть занесена в память компьютера либо воспроизведена любым способом без предварительного письменного разрешения издателя.

Подписано в печать 15.03.2013.

Формат 90×60/8.

Усл. печ. л. 10,5.

Заказ № 56/2013.

Тираж 500 экз.

Отпечатано в Издательстве Пермского национального исследовательского политехнического университета (Пермь, 614990, Комсомольский пр., 29, к. 113, тел. 2-198-033)

\section{АНАЛИЗ РИСКА ЗДОРОВЬЮ}

Научно-практический журнал. Основан в 2012 г.

Bыходит 4 раза в год

\section{РЕДАКЦИОННАЯ КОЛЛЕГИЯ}

Г.Г. Онищенко - главный редактор, акад. РАМН, д.м.н., проф. (г. Москва)

Н.В. Зайцева - заместитель главного редактора, акад. РАМН, д.м.н., проф. (г. Пермь)

И.В. Май - ответственный секретарь, д.б.н., проф. (г. Пермь)

\section{РЕДАКЦИОННЫЙ СОВЕТ}

С.Л. Авалиани - д.м.н., проф. (г. Москва)

А.Б. Бакиров - д.м.н., проф. (г. Уфа)

Е.Н. Беляев - чл.-корр. РАМН, д.м.н., проф. (г. Москва)

В.М. Боев - д.м.н., проф. (г. Оренбург)

И.В. Брагина - д.м.н (г. Москва)

Р.В. Бузинов - к.м.н. (г. Архангельск)

И.В. Бухтияров - д.м.н., проф. (г. Москва)

А.И. Верещагин - к.м.н. (г. Москва)

В.Б. Гурвич - д.м.н. (г. Екатеринбург)

И. Дардынская - д.м.н., проф. (г. Чикаго, США)

М.А. Землянова - д.м.н. (г. Пермь)

Н.Ф. Измеров - акад. РАМН, д.м.н., проф. (г. Москва)

У.И. Кенесариев - Д.м.н., проф. (г. Алматы, Казахстан)

Т. Кронберг - д.э.н., д.т.н. (г. Руваслахти, Финляндия)

С.В. Кузьмин - д.м.н., проф. (г. Екатеринбург)

В.В. Кутырев - Д.м.Н., проф. (г. Саратов)

В.Р. Кучма - д.м.н., проф. (г. Москва)

А.В. Мельцер - д.м.н., проф. (г. Санкт-Петербург)

А.Я. Перевалов - д.м.н., проф. (г. Пермь)

Ю.П. Пивоваров - акад. РАМН, д.м.н., проф. (г. Москва)

А.Я. Поляков - к.м.н. (г. Новосибирск)

А.Ю. Попова - д.м.н., проф. (г. Москва)

А.И. Потапов - акад. РАМН, д.м.н., проф. (г. Москва)

В.Н. Ракитский - акад. РАМН, д.м.н., проф. (г. Москва)

С.И. Савельев - д.м.н., проф. (г. Липецк)

В.Ф. Спирин - д.м.н., проф. (г. Саратов)

В.А. Тутельян - акад. РАМН, д.м.н., проф. (г. Москва)

Х.Х. Хамидулина - д.м.н., проф. (г. Москва)

В.А. Хорошавин - д.м.н. (г. Пермь)

С.А. Хотимченко - д.м.н., проф. (г. Москва)

Н.В. Шестопалов - д.м.н., проф. (г. Москва)

П.З. Шур - д.м.н. (г. Пермь)

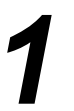

\section{Январь 2013 Март}


АКТУАЛЬНЫЕ АСПЕКТЫ АНАЛИЗА РИСКА ЗДОРОВЬЮ

Г.Г. Онищенко

ОЦЕНКА И УПРАВЛЕНИЕ РИСКАМИ ДЛЯ ЗДОРОВЬЯ КАК ЭФФЕКТИВНЫЙ ИНСТРУМЕНТ РЕШЕНИЯ ЗАДАЧ ОБЕСПЕЧЕНИЯ САНИТАРНО-ЭПИДЕМИОЛОГИЧЕСКОГО БЛАГОПОЛУЧИЯ НАСЕЛЕНИЯ РОССИЙСКОЙ ФЕДЕРАЦИИ

НАУЧНО-МЕТОДИЧЕСКИЕ ПОДХОДЫ К АНАЛИЗУ РИСКА

Н.В. Зайцева, П.В. Трусов, П.З. Шур, Д.А. Кирьянов, В.М. Чигвинцев, М.Ю. Цинкер МЕТОДИЧЕСКИЕ ПОДХОДЫ К ОЦЕНКЕ РИСКА ВОЗДЕЙСТВИЯ РАЗНОРОДНЫХ ФАКТОРОВ СРЕДЫ ОБИТАНИЯ НА ЗДОРОВЬЕ НАСЕЛЕНИЯ НА ОСНОВЕ ЭВОЛЮЦИОННЫХ МОДЕЛЕЙ

О.Н. Доброхотский, А.И. Дятлов ОСОБЕННОСТИ АНАЛИЗА РИСКА ЗДОРОВЬЮ ПРИ РАБОТЕ С ПАТОГЕННЫМИ БИОЛОГИЧЕСКИМИ АГЕНТАМИ

\section{ПРАВОВЫЕ АСПЕКТЫ ОЦЕНКИ РИСКА}

Т.Е. Науменко, В.А. Рыбак, Т.Д. Гриценко, Л.М. Шевчук, А.Е. Пшегрода, А.Н. Ганькин ЗАКОНОДАТЕЛЬНОЕ ОБЕСПЕЧЕНИЕ ОЦЕНКИ РИСКА ВОЗДЕЙСТВИЯ НА ЗДОРОВЬЕ НАСЕЛЕНИЯ КАЧЕСТВА АТМОСФЕРНОГО ВОЗДУХА В РЕСПУБЛИКЕ БЕЛАРУСЬ

М.С. Попов, А.Ю. Попова ОСНОВАНИЯ И ПРИНЦИПЫ ПРИМЕНЕНИЯ САНИТАРНЫХ И ФИТОСАНИТАРНЫХ МЕР В ПРАКТИКЕ ВСЕМИРНОЙ ТОРГОВОЙ ОРГАНИЗАЦИИ

\section{ПРАКТИКА ОЦЕНКИ РИСКОВ}

С.И. Савельев, В.А. Бондарев, Н.В. Нахичеванская, М.Ф. Полякова, Г.А. Юрьев, В.М. Салтыков, Е.А. Голованова ИСПОЛЬЗОВАНИЕ ДАННЫХ РЕГИОНАЛЬНОГО ИНФОРМАЦИОННОГО ФОНДА СГМ ДЛЯ ОЦЕНКИ РИСКА ЗДОРОВЬЮ НАСЕЛЕНИЯ Г. ЛИПЕЦКА

\section{URGENT ASPECTS OF RISK ANALYSIS}

4 G.G. Onischenko HEALTH RISK ASSESSMENT AND MANAGEMENT AS AN EFFECTIVE TOOL TO SOLVE ISSUES TO ENSURE THE HEALTH AND EPIDEMIOLOGICAL WELL-BEING OF THE RUSSIAN FEDERATION POPULATION

\section{SCIENTIFIC AND METHODICAL APPROACHES TO RISK ANALYSIS}

15 N.V. Zaitseva, P.V. Trusov, P.Z. Shur, D.A. Kiryanov, V.M. Chigvintsev, M.Yu. Tsinker METHODICAL APPROACHES TO HEALTH RISK ASSESSMENT OF HETEROGENEOUS ENVIRONMENTAL FACTORS BASED ON EVOLUTIONARY MODELS

24 O.N. Dobrokhotskiy, A.I. Dyatlov THE CHARACTERISTICS OF HEALTH RISK ANALYSIS WHEN WORKING WITH PATHOGENIC BIOLOGICAL AGENTS

\section{LEGAL ASPECTS OF RISK ASSESSMENT}

30 T.Ye. Naumenko, V.A. Rybak, T.D. Gritsenko, L.M. Shevchuk, A.Ye. Pshegroda, A.N. Gankin THE LEGISLATIVE BASIS FOR ASSESSING THE RISK OF THE IMPACT OF AMBIENT AIR QUALITY ON HUMAN HEALTH IN THE REPUBLIC OF BELARUS

36 M.S. Popov, A.Yu. Popova THE FOUNDATIONS AND PRINCIPLES OF APPLYING SANITARY AND PHYTOSANITARY MEASURES IN WORLD TRADE ORGANIZATION PRACTICE

\section{RISK ASSESSMENT PRACTICE}

41 S.I. Savelyev, V.A. Bondarev, N.V. Nakhichevanskaja, M.F. Polyakova, G.A. Yuriev, V.M. Saltykov,

E.A. Golovanova USING DATA FROM A REGIONAL INFORMATION FUND OF SOCIAL AND ENVIRONMENTAL HEALTH MONITORING TO ASSESS HUMAN HEALTH RISKS IN LIPETSK 
Н.В. Ерастова, А.В. Мельцер ГИГИЕНИЧЕСКОЕ ОБОСНОВАНИЕ ПРОФИЛАКТИЧЕСКИХ МЕР ДЛЯ ОБЕСПЕЧЕНИЯ НАСЕЛЕНИЯ Г. САНКТ-ПЕТЕРБУРГА ПИТЬЕВОЙ ВОДОЙ ВЫСОКОГО КАЧЕСТВА

У.И. Кенесариев, А.Т. Досмухаметов, М.К. Амрин, А.Е. Ержанова, А.А. Баймухамедов ИНТЕГРАЛЬНАЯ ОЦЕНКА РИСКА ЗДОРОВЬЮ ПРИ ИСПОЛЬЗОВАНИИ ПИТЬЕВОЙ ВОДЫ, ПРОИЗВОДИМОЙ ОПРЕСНИТЕЛЬНЫМ ЗАВОДОМ «КАСПИЙ»

ЭКСПЕРИМЕНТАЛЬНЫЕ МОДЕЛИ И ИНСТРУМЕНТАЛЬНЫЕ ИССЛЕДОВАНИЯ

Н.В. Зайцева, М.А. Землянова, В.Н. Звездин, Е.В. Саенко

ТОКСИКОЛОГО-ГИГИЕНИЧЕСКАЯ ОЦЕНКА БЕЗОПАСНОСТИ ВОДНОЙ СУСПЕНЗИИ НАНОДИСПЕРСНОГО ДИОКСИДА КРЕМНИЯ, СИНТЕЗИРОВАННОГО МЕТОДОМ ЖИДКОКРИСТАЛЛИЧЕСКОГО ТЕМПЛАТИРОВАНИЯ

\section{АНАЛИТИЧЕСКИЕ ОБЗОРЫ}

Д.В. Ланин

АНАЛИЗ КОРЕГУЛЯЦИИ ИММУННОЙ И НЕЙРОЭНДОКРИННОЙ СИСТЕМ В УСЛОВИЯХ ВОЗДЕЙСТВИЯ ФАКТОРОВ РИСКА
52 N.V. Erastova, A.V. Meltser THE HYGIENIC JUSTIFICATION OF PREVENTIVE MEASURES TO PROVIDE THE ST PETERSBURG POPULATION WITH HIGH QUALITY DRINKING WATER

58 U.I. Kenessaryiev, A.T. Dosmukhametov, M.K. Amrin, A.E. Yerzhanova, A.A. Baimukhamedov ASSESSMENT OF INTEGRATED HEALTH RISK WHILE USING DRINKING WATER PRODUCED BY DESALINATION PLANT «CASPIAN»

\section{EXPERIMENTAL MODELS AND MEASUREMENT STUDIES}

65 N.V. Zaitseva, M.A. Zemlyanova, V.N. Zvezdin, Ye.V. Sayenko TOXICOLOGICAL AND HYGIENIC SAFETY ASSESSMENT OF THE AQUEOUS SUSPENSION OF NANO-DISPERSED SILICON DIOXIDE, SYNTHESIZED USING LIQUID-CRYSTAL TEMPLATING

\section{ANALYTICAL REVIEWS}

73 D.V. Lanin THE ANALYSIS OF THE CO-REGULATION BETWEEN THE IMMUNE AND NEUROENDOCRINE SYSTEMS UNDER EXPOSURE TO RISK FACTORS 


\section{ОЦЕНКА И УПРАВЛЕНИЕ РИСКАМИ ДЛЯ ЗДОРОВЬЯ КАК ЭФФЕКТИВНЫЙ ИНСТРУМЕНТ РЕШЕНИЯ ЗАДАЧ ОБЕСПЕЧЕНИЯ САНИТАРНО-ЭПИДЕМИОЛОГИЧЕСКОГО БЛАГОПОЛУЧИЯ НАСЕЛЕНИЯ РОССИЙСКОЙ ФЕДЕРАЦИИ}

\section{Г.Г. Онищенко}

Федеральная служба в сфере защиты прав потребителей и благополучия человека, Россия, 127994, г. Москва, Вадковский переулок, д. 18, стр. 5 и 7

В Российской Федерации продолжается формирование гармонизированной с международными требованиями и подходами законодательной, научно-методической и информационной базы методологии оценки риска здоровью при воздействии вредных факторов среды обитания. Включенные в систему социально-гигиенического мониторинга, апробированные и доказавшие эффективность методы оценки риска для здоровья использованы во многих регионах России при обосновании санитарно-гигиенических мероприятий по охране здоровья населения, работающих, при анализе безопасности продукции и т.п. С учетом параметров риска разработан ряд отечественных гигиенических нормативов содержания химических веществ в объектах среды обитания, обоснована позиция Российской Федерации по вопросам содержания остаточных количеств вредных примесей в продуктах питания, сформированы программы контроля качества атмосферного воздуха в период проведения Универсиады в Казани и Олимпийских игр в Сочи. В стране развивается методическая и лабораторная база социально-гигиенического мониторинга как основы оценки экспозиции, апробируются новые подходы к установлению и математическому моделированию взаимосвязей «доза-эффект», классификации рисков, в том числе при воздействии факторов различной природы, использованию результатов оценки рисков при принятии управленческих решений в сфере обеспечения санитарно-эпидемиологического благополучия.

Ключевые слова: оценка риска, управление рисками, практика применения.

Современный этап развития Российской Федерации характеризуется интенсивным включением страны в мировые интеграционные процессы, ускорением развития инновационных производств, что связано с появлением новых угроз и опасностей для здоровья населения, затрудняющих выполнение стратегических задач, поставленных перед органами государственной власти, по сохранению здоровья нации, снижению уровня смертности, увеличению продолжительности жизни, формированию мотивации для ведения здорового образа жизни [1-5]. В этой связи сегодня важным является внедрение в практику Федеральной службы по надзору в сфере защиты прав потребителей и благополучия человека новых эффективных наукоемких инструментов, обеспечивающих управление санитарно-эпидемиологической обстановкой. Один из таких инструментов - методология анализа рисков здоровью населения, связанных с негативным воздействием неблагоприятных факторов среды обитания.

Указанная методология, позволяющая использовать надежные количественные оценочные критерии, широко применяется в странах Европейского содружества, США, Канаде и ряде других государств с целью обеспечения безопасности для здоровья человека среды обитания, продукции, производственных технологий и процессов, в том

(C) Онищенко Г.Г., 2013

Онищенко Геннадий Григорьевич - академик РАМН, доктор медицинских наук, профессор; руководитель (e-mail: depart@gsen.ru, тел.: +7 (499) 973-26-90). 
числе при гармонизации законодательных основ, правовых норм, санитарно-гигиенических стандартов и требований.

Существующие процедуры и методические подходы к оценке риска здоровью с учетом накопленного положительного отечественного опыта и наработанной гигиенической практики нашли свое отражение в отечественной законодательной базе. Так, Федеральный закон от 30.03.1999 г. № 52-Ф3 «О санитарно-эпидемиологическом благополучии населения» предусматривает прогнозирование социальных, экономических и медико-демографических последствий применения санитарных правил, критерии для которых основаны на принципе безопасности для здоровья населения. В рамках санитарного законодательства установлена обязанность опасных хозяйствующих субъектов выполнять оценку риска при проектировании санитарно-защитных зон (СанПиН 2.2.1/2.1.1.1200-03 «Санитарно-защитные зоны и санитарная классификация предприятий, сооружений и иных объектов»), порядок оценки риска при воздействии факторов химической природы и критерии приемлемого (допустимого) риска приведены в Р 2.1.10.1920-04 «Руководство по оценке риска для здоровья населения при воздействии химических веществ, загрязняющих окружающую среду». В области обеспечения радиационной безопасности используются законодательно закрепленные показатели предела индивидуального риска возникновения стохастических эффектов...» (НРБ-99). Разработана система оценки профессионального риска и сформулированы основные принципы управления профессиональным риском (Р 2.2.1766-03 «Руководство по оценке профессионального риска для здоровья работников. Организационно-методические основы, принципы и критерии оценки»). Положение о безопасности продукции (товаров) (т.е. об отсутствии недопустимого риска жизни и здоровью) рассматривается в качестве одного из основных в Федеральном законе от 27.12.2012 г. № 184-Ф3 «О техническом регулировании.
Ведется целенаправленная работа по сближению накопленного в Российской Федерации опыта гигиенических оценок с принципами и методами оценки риска [6]. Так, отечественная методология оценки профессиональных рисков опирается на результаты международного проекта России и Европейского союза EuropeAid 119764/C/SV/RU «Сближение нормативной правовой базы по охране труда и безопасности», а также документы Международной организации охраны труда, которой было рекомендовано «... определить процедуру оценки риска как предварительный этап аттестации рабочих мест, выработать минимальные критерии оценки рисков». Сформулирована концепция реформы системы охраны труда до 2025 г., предприняты масштабные меры по модернизации системы охраны труда и обязательного социального страхования. Формируется полноценная система управления профессиональными рисками, основанная на идентификации всех опасностей на рабочих местах, их количественной оценке и ведении соответствующих записей, мониторинге проводимых измерений с последующим установлением взаимосвязей состояния условий труда и состояния здоровья работников на основе определения индивидуальных профессиональных рисков работников.

Вместе с тем в Российской Федерации на базе накопленного мирового опыта создаются уникальные методические подходы к оценке риска, позволяющие отстаивать позиции в области обеспечения санитарноэпидемиологического благополучия страны. Только за последние два года Федеральной службой по надзору в сфере защиты прав потребителей и благополучия человека утверждено и рекомендовано к внедрению более десятка документов, ориентированных на оценку риска для здоровья населения при воздействии вредных факторов среды обитания. Среди них методические указания «Оценка радиационного риска у населения за счет длительного равномерного техногенного облучения в малых дозах», методические рекомендации «Оценка риска и ущерба 
от климатических изменений, влияющих на повышение уровня заболеваемости и смертности в группах населения повышенного риска», «Комплексная оценка риска возникновения бактериальных кишечных инфекций, передаваемых водным путем», «Оценка риска здоровью населения при воздействии факторов микробной природы, содержащихся в пищевых продуктах. Методические основы, принципы и критерии оценки», «Оценка риска здоровью населения от воздействия транспортного шума», «Количественная оценка неканцерогенного риска при воздействии химических веществ на основе построения эволюционных моделей», документы, посвященные вопросам оценки риска при воздействии электромагнитных излучений, факторов образа жизни, проблемам экономической оценки риска и ущербов и пр. Подготовлены методики интегральной оценки условий труда на рабочем месте с учетом комплексного воздействия производственных факторов с различными классами вредности и расчета вероятности утраты работником трудоспособности в зависимости от состояния условий труда на рабочем месте. Предложены подходы к расчету индивидуального профессионального риска в зависимости от условий труда и состояния здоровья работника и расчету интегрального показателя уровня профессионального риска в организации. Разработаны регламент по идентификации опасностей и оценке рисков травмирования на рабочих местах с вредными и опасными условиями труда, включая классификатор (каталог) опасностей и систему регламентов и стандартов «Документированные процедуры и стандарты организации и проведения аттестации рабочих мест и оценки профессиональных рисков».

Развитие методологии оценки риска здоровью позволяет формировать научный базис для защиты интересов граждан Российской Федерации и стран Таможенного союза, в том числе в отношении безопасности пищевых продуктов, экспортируемых из-за рубежа.

В настоящее время деятельность службы, направленная на обеспечение безопас- ности продуктов питания населения Российской Федерации, определяется следующими основными документами: Федеральный закон от 30.03.1999 г. № 52-Ф3 «О санитарноэпидемиологическом благополучии населения» (положения закона приведены в соответствие с международными документами, устанавливающими исчерпывающий перечень форм обязательной оценки соответствия продукции санитарно-эпидемиологическим требованиям); Федеральный закон от 27.12.2002 г. № 184-Ф3 «О техническом регулировании», устанавливающий обязательные требования к безопасности выпускаемой продукции; «Доктрина продовольственной безопасности Российской Федерации» (утверждена указом президента Российской Федерации от 30.01.2010 г. № 120); «Основы государственной политики в области здорового питания населения до 2020 года» (утверждены распоряжением правительства Российской Федерации от 25.10.2010 г. № 1873-p. В целях повышения качества и безопасности пищевых продуктов и качества питания населения Российской Федерации введены в действие федеральные законы, утвердившие ряд технических регламентов, в том числе Федеральный закон от 12.06.2008 г. № 88-Ф3 «Технический регламент на молоко и молочную продукцию»; Федеральный закон от 24.06.2008 г. № 90-Ф3 «Технический регламент на масложировую продукцию»; Федеральный закон от 27.10.2008 г. № 178-Ф3 «Технический регламент на соковую продукцию из фруктов и овощей» и др.

В июле 2012 г. Россия стала 156-м полноправным членом Всемирной торговой организации (ВТО) и приступила к исполнению обязательств, взятых на себя в результате переговорного процесса по присоединению, который начался еще в 1995 г. Часть этих обязательств требует принятия дополнительных мер, связанных с изменением принципов осуществления государственного санитарноэпидемиологического нормирования и внесением изменений в действующие нормативы и Таможенного союза, и Российской Федерации. В области безопасности продовольственного сырья и пищевых продуктов 
в Российской Федерации и на территории Таможенного союза контролируется более 7 тыс. санитарно-эпидемиологических показателей. Роспотребнадзор принимал активное участие при подготовке нормативной базы соглашения Таможенного союза по санитарным мерам, в рамках работы было гармонизировано более 3 тыс. показателей. При этом при подготовке предложений к изменению нормативов принимаются во внимание стандарты, рекомендованные Комиссией «Кодекс Алиментариус» (Codex Alimentarius), а также нормативы, установленные в Европейском союзе, что мотивируется сходной структурой потребления.

Одним из главных требований, предъявляемых странами - членами ВТО к Российской Федерации, является выполнение принципов соглашения ВТО по санитарным и фитосанитарным мерам. Принципы гармонизации, эквивалентности оценки риска уже отражены в ряде правовых актов, принятых на уровне Комиссии Таможенного союза в 2011 г. («О гармонизации санитарных и фитосанитарных мер с международными стандартами») и на уровне правительства Российской Федерации, что связано с реализацией планов адаптации российской экономики к условиям членства в ВТО.

В результате проделанной Роспотребнадзором работы гармонизированы с международными стандартами требования к максимально допустимым уровням (МДУ) остаточных количеств целого ряда антибиотиков и пестицидов в продуктах питания. Так, научно-исследовательскими организациями Роспотребнадзора совместно с НИИ питания РАМН с использованием методологии оценки риска было представлено соответствующее научное обоснование сохранения в российском законодательстве текущих показателей МДУ остаточных количеств тетрациклинов в продуктах питания животного происхождения. Подтверждена позиция российской делегации, высказанная на 35-й сессии Комиссии «Кодекс Алиментариус», о том, что допустимая суточная доза рактопамина недостаточно обоснована и не может быть использована для установления максимально допустимых уровней содержания этого вещества в мясе и субпродуктах. Оценка риска показала, что употребление пищевых продуктов при наличии в них допустимых остаточных количеств рактопамина на уровне, рекомендованном Комиссией «Codex Alimentarius», приведет к неприемлемому риску появления функциональных нарушений, болезней сердечно-сосудистой системы и сокращению прогнозируемой продолжительности жизни населения Российской Федерации (в Российской Федерации заболевания сердца и сосудов обусловливают более половины смертей населения). В связи с полученными данными Роспотребнадзор продолжает отстаивать свою позицию относительно содержания рактопамина в пищевых продуктах и планирует продолжить работу по гармонизации МДУ потенциально опасных веществ в пищевых продуктах в рамках плана совместных действий с директоратом Еврокомиссии по здравоохранению и защите потребителей. Взаимодействие Роспотребнадзора с заинтересованными членами ВТО по вопросу гармонизации требований к наличию остаточных количеств антибиотиков, пестицидов и других веществ в пищевых продуктах также будет продолжено.

Методология оценки риска здоровью активно используется при решении ряда задач гигиенической оценки ситуации и обоснования санитарно-гигиенических мероприятий самого разного уровня [7]. Этому способствовало создание на базе ФБУЗ «Федеральный центр гигиены и эпидемиологии» Роспотребнадзора системы аккредитации органов по оценке риска. Система сыграла важнейшую роль в обеспечении качества гигиенических исследований по оценке риска здоровью, подготовки высококвалифицированных кадров в области оценки риска в стране, обеспечила тиражирование лучшей практики оценки риска.

Впервые в современной истории России по инициативе Федеральной службы по надзору в сфере защиты прав потребителей и благополучия человека Продовольственная и сельскохозяйственная организация 
$\mathrm{OOH}$ (Food and Agriculture Organization) coвместно с Комиссией «Codex Alimentarius» в апреле 2013 г. проведут в Москве заседание Комитета Кодекса по загрязняющим примесям в пищевых продуктах (Codex Committee On Contaminants In Food). Участие в этом мероприятии в качестве принимающей стороны и сопредседателя позволит в дальнейшем развивать деятельность Российской Федерации в Комиссии «Codex Alimentarius», в том числе более активное в процессе разработки международных стандартов качества пищевых продуктов, что должно обеспечить высокий уровень защиты российских потребителей.

В настоящее время в стране действует порядка 50 организаций, аккредитованных в Системе аккредитации органов по оценке риска, которые представляют Центральный, Северо-Западный, Приволжский, Уральский, Южный, Северо-Кавказский и Дальневосточный федеральные округа. Число исследований по оценке риска постоянно увеличивается и составляет в последние годы 280-300 проектов в год (2006 г. - 120 проектов). Наибольшее число исследований выполняется с целью обоснования размеров санитарно-защитных зон, что определяется наличием правовой базы. Ряд работ направлен на оценку риска в связи с использованием населением питьевых вод, продуктов питания, проживанием на территориях с загрязненными почвами. Важным аспектом является то, что результаты оценки риска ложатся в основу действий самой службы, органов государственной власти, местного самоуправления, хозяйствующих субъектов [8-10].

Результаты оценки риска здоровью позволяют на высоком научном уровне обеспечивать участие России в масштабных международных проектах. Так, с учетом опыта подготовки и проведения Олимпийских игр в Афинах (2004 г.), Пекине (2008 г.), Лондоне (2012 г.) по критериям риска для здоровья выполнено обоснование приоритетных загрязнителей атмосферного воздуха, подлежащих санитарно-эпидемиологическому контролю в период проведения летней Уни- версиады 2013 г. в г. Казани и XXII Олимпийских зимних игр 2014 г. в г. Сочи. При оценке экспозиции принимались во внимание особенности дыхания у спортсменов при высоких физических нагрузках, метеорологические условия места проведения спортивного мероприятия, планировка спортивных и социально-бытовых объектов, особенности проектируемой улично-дорожной сети, интенсивности и структуры транспортных потоков в период проведения массового спортивного мероприятия, а также режимы работы производственных объектов. Такие подходы являются гарантией соблюдения гигиенической безопасности жителей и гостей городов, в которых проводятся массовые спортивные мероприятия, позволяют Российской Федерации соответствовать самым жестким международным стандартам в области обеспечения санитарно-эпидемиологического благополучия населения, формируют благоприятный имидж страны.

Методология оценки риска здоровью востребована при формировании программ безопасного развития на региональном и муниципальном уровнях.

Результаты оценки риска, полученные в ходе исследования загрязнения атмосферного воздуха г. Москвы, позволили внести предложения в Программу социально-экономического развития одного из административных округов столицы на среднесрочную перспективу по разработке 6 проектов организации санитарно-защитных зон для предприятий округа.

Роспотребнадзором Кемеровской области по итогам работ по оценке риска здоровью населения подготовлены предложения в адрес администрации Кемеровской области и администраций муниципальных образований по разработке программы развития системы водоснабжения и водоотведения на территории одного из муниципальных образований, по утверждению Программы мероприятий по защите прав потребителей и обеспечению санитарно-эпидемиологического благополучия населения г. Новокузнецка на 2011-2013 гг. (в проект программы вошли мероприятия по улучшению 
качества атмосферного воздуха города, водоснабжения населения, оздоровлению реки Томь).

В Липецкой области исследование по оценке риска для здоровья населения, связанного с качеством питьевой воды подземного источника поселка Матырский, позволило обосновать план дополнительных лабораторных исследований воды водоисточника на содержание в ней мышьяка, свинца, кадмия, никеля, хрома.

Гигиеническая оценка влияния факторов среды обитания на состояние здоровья населения муниципальных образований Свердловской области за период 2008-2010 гг. позволила установить, что в условиях комплексной химической нагрузки проживает $83 \%$ населения области (или более 3568 тыс. человек), и разработать программу мер, направленных на минимизацию рисков здоровью, связанных с факторами среды обитания.

Результаты реализации методологии оценки риска с применением элементов эпидемиологического анализа и диагностики напряженности санитарно-гигиенической ситуации были положены в основу разработки ряда медико-профилактических технологий, рекомендуемых для внедрения в практику. Так, в ряде регионов создана и успешно реализована 3-ступенчатая организационно-функциональная модель оказания специализированной медицинской помощи детям с экологически модифицированным течением болезней органов дыхания (аллергический бронхит, бронхиальная астма), органов пищеварения (заболевания гастродуоденальной сферы, гепатобилиарной системы), сердечно-сосудистой, нервной систем и органов чувств (вегетососудистая дистония, дисфункции нервной системы), болезней кожи и ее придатков (атопический дерматит, алопеции и др.), болезней костно-мышечной системы (остеомиелит, остеопорозы), эндокринной системы (эндемический зоб, ожирение и т.д.) и др.

Широкий перечень исследований выполняется в части оценки профессиональных и производственно обусловленных рисков здоровью, что крайне значимо в услови- ях, когда показатель смертности населения трудоспособного возраста в Российской Федерации превышает аналогичные показатели Евросоюза в 4,5 раза [6]. Выявлено, что с внедрением новых безопасных технологий на отдельных предприятиях снижается риск возникновения профессиональных заболеваний в тяжелой форме, чаще регистрируются заболевания без четких биологических маркеров на основе смешанного - профессионального и возрастного - генеза. Это заболевания со стертыми клиническими формами у высокостажированных пациентов (стаж 20 лет и более), у которых выявляются различные нарушения здоровья возрастного характера. Поэтому крайне важное значение имеет определение среднестажевого порога риска в сопоставлении с параметрами вредных факторов на производстве, за пределами которого возникает опасность формирования «профессионально обусловленного» (индуцированного) заболевания. Данная проблема актуальна еще и потому, что в последние годы многие рабочие даже при существенном превышении предельно допустимого уровня вредных факторов на рабочем месте, несмотря на наличие среднестажевого порога риска, продолжают работать во вредных условиях труда, подвергая свое здоровье опасности. Подобная практика недопустима, поэтому в настоящее время, как никогда, актуально осознанное представление о рисках для здоровья в различных возрастных группах. Предложены методические подходы к обоснованию допустимых уровней риска появления неинфекционных заболеваний и связанных с ними экономических потерь как критериев безопасности при долгосрочном планировании. Разработаны методы и критерии оценки прямых и отдаленных последствий, обусловленных воздействием неблагоприятных факторов среды обитания.

Методология анализа риска здоровью является одним из наиболее динамично развивающихся научных инструментов. В целом следует отметить, что органами и научными учреждения Федеральной службы в сфере защиты прав потребителей и благо- 
получия человека накапливаются значительные знания о негативных эффектах, возникающих под влиянием отдельных вредных факторов внешней среды, их совокупности и сочетании. При этом фундаментальные и прикладные научные исследования выполняются в отношении всех этапов анализа риска: идентификации опасности, оценки экспозиции, оценки зависимостей «доза-эффект», характеристики риска, оценки неопределенности, управления и информирования о рисках.

Выполняются исследования, направленные на изучение параметров дисперсного и компонентного состава пылевых фракций выбросов основных производств с выделением фракций $\mathrm{PM}_{10}, \mathrm{PM}_{2,5}$, что крайне важно для оценки экспозиции как работающих, так и населения. Данные актуальны и для научных обоснований при согласовании органами Роспотребнадзора предельно допустимых выбросов предприятий и организаций и проектирования санитарно-защитных зон.

Интенсивно развиваются исследования по оценке риска для здоровья работающих и населения от влияния наночастиц и наноматериалов [11], что сопровождается опережающим развитием современной лабораторной базы органов и организаций Роспотребнадзора и обращением к наукоемким центрам коллективного пользования РАН и РАМН.

Сегодня крайне существенно сопряжение работ по оценке риска с развитием методов формирования доказательной базы реализации рисков для здоровья в виде поражений здоровья (через эпидемиологические или углубленные медико-биологические исследования). При этом значимым и постоянно поддерживаемым направлением деятельности Федеральной службы по надзору в сфере защиты прав потребителей и благополучия человека является развитие на базе научных организаций Роспотребнадзора современных химико-аналитических, клеточных, цитогенетических, протеомных, метаболомных и иных наукоемких способов диагностики нарушений состояния здоровья при воздействии вредных факторов внешней среды. Необходимо отметить, что в последние годы механизмы токсического действия химических веществ во многих случаях устанавливаются по геноэффектам и действию релевантных метаболитов. Направленные клеточные и субклеточные исследования - зачастую дорогостоящие процедуры, однако арбитражная ценность получаемых данных крайне высока. Оценка риска позволяет значительно сузить круг поиска как факторов воздействия, так и вероятных нарушений здоровья экспонируемого населения и существенно сэкономить время и средства на сбор доказательной базы, подтверждающей наличие вреда здоровью. Применяемые при оценке риска подходы позволяют к тому же выявить конкретные источники и причины загрязнения среды обитания, определить долевые вклады путей поступления и конкретных факторов опасности.

В целом на текущий момент методология оценки риска с учетом развивающихся методов гигиенической диагностики может вооружить службу как научным инструментарием, так и фактическими данными для обоснования наличия связи в системе «среда-здоровье», в том числе при досудебной и судебной защите прав граждан на благоприятную среду обитания.

Примеры практического использования рассматриваемых подходов уже имеются. Так, в Пермском крае по результатам оценки риска здоровью населения г. Краснокамска (более 80 тыс. населения), потребляющего гиперхлорированную питьевую воду выявлено, что суммарный индивидуальный канцерогенный риск в 4,6 раза превышает приемлемый уровень, при этом в качестве доказательств формирования нарушений здоровья, детерминированных факторами среды обитания, использованы химико-аналитические методы определения химических веществ в биологических субстратах, клеточные и субклеточные методы диагностики нарушений биохимического, иммунологического, цитогенетического статуса организма, средства математического моделирования. В ходе направленных исследований установлено, что хлоро- 
форм, который был идентифицирован как основная причина возникновения неприемлемого прогнозируемого риска для здоровья, присутствовал в крови 98,8 \% обследованных детей при уровне сравнения - ниже порога определения метода. У всех обследованных детей в крови был идентифицирован четыреххлористый углерод; у 97,9\% - дихлорбромметан. У каждого второго обследованного ребенка, постоянно потребляющего воду централизованной системы водоснабжения города, в крови присутствовали дибромхлорметан и/или 1,2-дихлорэтан. Доказаны достоверные причинно-следственные связи $(p<0,5)$ между уровнями загрязняющих примесей в крови детей и показателями повреждения клеток, снижения белково-синтетической функции печени, нарушением баланса окислительно-восстановительных процессов, снижением неспецифической резистентности и развитием интоксикации организма. Доказано, что изменения клеточного (фагоцитоз, Т-лимфоциты) и гуморального (иммуноглобулины и цитокины) иммунитета связаны с повышенной частотой и тяжестью заболеваний у обследованных пациентов. Полученные результаты использованы при подготовке постановления главного государственного санитарного врача Пермского края о запрещении использования питьевой воды г. Краснокамска как не отвечающей требованиям безопасности.

За последние десятилетия методология оценки риска в России прошла путь от упрощенной методической схемы, предусматривающей изолированную оценку воздействия фактора (на первых этапах в основном химического), поступающего из одной среды, до оценки рисков негативных эффектов различной тяжести в результате одновременного воздействия на человека группы факторов различной природы. В качестве основной тенденции развития методологии оценки риска можно выделить стремление наиболее полно приблизить ее к характеристике реального влияния факторов среды обитания в условиях воздействия различных комплексов факторов, при различных сце- нариях экспозиции. Все большее значение приобретают методы математического моделирования, которые в настоящее время используются не только при расчете экспозиции или при установлении зависимостей «экспозиция-эффект/ответ», но и при динамической оценке риска здоровью, основанной на оценке механизмов эволюции рисков.

Целесообразно, чтобы развитие методологии оценки риска сопровождалось формированием соответствующей законодательной и нормативно-правовой базы оценки и управления риском. Это позволило бы унифицировать систему терминов по вопросам оценки риска в действующих в Российской Федерации законодательных и подзаконных актах и полностью гармонизировать ее с международными документами, в том числе в отношении понятия приемлемого (допустимого) риска, стимулировать дальнейшее совершенствование методологии оценки риска и ее внедрение в практику принятия решений по обеспечению санитарно-эпидемиологического благополучия населения. Крайне важной для развития методологии оценки риска является организация унифицированных межрегиональных эпидемиологических исследований, позволяющих устанавливать причинно-следственные связи нарушений здоровья граждан с негативным воздействием среды обитания и объектов технического регулирования, накапливать отечественную базу параметров для оценки риска, связанного с воздействием разнородных факторов среды обитания и образа жизни.

С целью развития достижений в области формирования научных основ отечественной методологии анализа рисков здоровью и внедрения ее в деятельность Роспотребнадзора актуальным представляется:

- совершенствование законодательной, нормативно-правовой и методической базы анализа рисков здоровью населения, в том числе в сфере технического регулирования, с учетом международных обязательств Российской Федерации в связи с вхождением в ряд объединений и союзов, особенно при оценке безопасности продукции и опасных объектов; 
- развитие методологии анализа риска в направлении количественной оценки рисков здоровью, в том числе интегральных;

- развитие методической и лабораторной базы социально-гигиенического мониторинга как информационной основы оценки экспозиции населения с расширением доли наукоемких методов исследований, обеспечивающих корректную и оперативную оценку уровней воздействия на население и работающих;

- расширение практики организации и проведения национальных эпидемиологических проектов, позволяющих выявлять устойчивые, характерные для условий Российской Федерации, зависимости между факторами воздействия и нарушениями здоровья населения;

- включение принципов и методов оценки риска в систему гигиенического нормирования;

- развитие экономических оценок рисков здоровью с выходом на системы страхования рисков для работающих во вредных условиях труда и для населения в целом;

- включение показателей оценки рисков здоровью населения в критерии оценки деятельности органов власти субъектов Российской Федерации и органов местного самоуправления;
- расширение международного обмена результатами научных исследований с увеличением количества российских данных по анализу риска здоровью в международных научных изданиях;

- повышение качества подготовки специалистов в области оценки рисков;

- оснащение практической службы Роспотребнадзора прикладными программно-аппаратными средствами, позволяющими выполнять наукоемкий анализ в рамках текущей надзорной деятельности.

Законодательное, методическое и информационное развитие методологии анализа рисков здоровью в стране и применение ее в деятельности Федеральной службы в сфере защиты прав потребителей и благополучия человека позволит повысить эффективность мер в области обеспечения санитарно-эпидемиологического благополучия населения, способствовать установлению более надежных гигиенических нормативов и безопасных уровней вредных факторов и направленно обосновывать меры профилактики нарушений здоровья, что позволит в полной мере выполнить задачи Роспотребнадзора по реализации государственной политики по сохранению здоровья нации и повышению качества жизни населения страны.

\section{Список литературы}

1. Концепция долгосрочного социально-экономического развития Российской Федерации на период до 2020 года: утв. распоряжением Правительства Российской Федерации от 17 ноября 2008 года № 1662-р [Электронный ресурc]. - URL: http://www.ifap.ru/ofdocs/rus/rus006.pdf (дата обращения: 17.11.2008).

2. Стратегия национальной безопасности Российской Федерации до 2020 года: утв. указом Президента Российской Федерации от 12 мая 2009 года № 537 [Электронный ресурc]. - URL: http://nvo.ng.ru/ concepts/2009-05-15/7_strategy4.html (дата обращения: 12.05.2009).

3. Современная демографическая ситуация в стране. Аналитический материал Федеральной службы государственной статистики [Электронный ресурс]. - http://www.gks.ru/wps/wcm/connect/rosstat/rosstatsite/main/ population/demography/ (дата обращения: 09.02.2012).

4. О состоянии санитарно-эпидемиологического благополучия населения в Российской Федерации в 2011 году: государственный доклад. - М.: Федеральный центр гигиены и эпидемиологии Роспотребнадзоpa, 2012. -323 c.

5. Онищенко Г.Г. Основные итоги и перспективы обеспечения санитарно-эпидемиологического благополучия населения // Материалы XI Всероссийского съезда гигиенистов и санитарных врачей / под ред. акад РАМН Г.Г. Онищенко, акад РАМН проф. А.И. Потапова. - М., Ярославль: Канцлер, 2012. - С. 30-40.

6. Потапов А.И., Ракитский В.Н. Проблемы современной гигиены // Материалы ХІ Всероссийского съезда гигиенистов и санитарных врачей / под ред. акад. РАМН проф. Г.Г. Онищенко, акад. РАМН проф. А.И. Потапова. - М., Ярославль: Канцлер, 2012. - С. 40-49. 
7. Измеров Н.Ф., Денисов Э.И., Морозова Т.В. Охрана здоровья работников: гармонизация терминологии, законодательства и практики с международными стандартами // Медицина труда и промышленная экология. - 2012. - № 8. - С. 1-7.

8. Комплексные вопросы управления риском здоровью в решении задач обеспечения санитарноэпидемиологического благополучия на муниципальном уровне / Н.В. Зайцева, П.З. Шур, И.В. Май, А.С. Сбоев, О.Л. Волк-Леонович, Т.В. Нурисламова // Гигиена и санитария. - 2007. - № 5. - С. 16-18.

9. Система управления санитарно-эпидемиологической обстановкой с использованием социальногигиенического мониторинга и методологии оценки риска для здоровья населения / С.В. Кузьмин, В.Б. Гурвич, С.В. Ярушин, О.В. Малых, С.В. Романов, Е.А. Кузьмина, С.А. Воронин, Н.И. Кочнева // Материалы научно-практической конференции «Гигиенические и методико-профилактические технологии управления рисками здоровью населения в промышленно развитых регионах» / под ред. акад. РАМН Г.Г. Онищенко, чл.-корр. РАМН Н.В. Зайцевой, 6-8 октября 2010. - Пермь, 2010. - С. 73-78.

10. Май И.В., Хорошавин В.А., Евдошенко В.С. Алгоритм и методы санитарно-эпидемиологического расследования нарушений прав граждан на окружающую среду с этапом оценки риска для здоровья // Здоровье населения и среда обитания. - 2010. - № 11. - С. 28-30.

11. Онищенко Г.Г. Организация надзора за оборотом материалов, представляющих потенциальную опасность для здоровья человека // Гигиена и санитария. - 2011. - № 2. - С. 4-9.

\section{References}

1. Kontseptsiya dolgosrochnogo sotsial'no-ekonomicheskogo razvitiya Rossiyskoy Federatsii na period do 2020 goda [The concept of long-term socio-economic development of the Russian Federation over the period until 2020]. Utverzhdena rasporyazheniem Pravitel'stva Rossiyskoy Federatsii ot 17 noyabrya 2008 goda № 1662-r. Available at: http://www.ifap.ru/ofdocs/rus/rus006.pdf.

2. Strategiya natsional'noy bezopasnosti Rossiyskoy Federatsii do 2020 goda [The National Security Strategy of the Russian Federation until 2020]. Utverzhdena Ukazom Prezidenta Rossiyskoy Federatsii ot 12 maya 2009 goda № 537. Available at: http://nvo.ng.ru/concepts/2009-05-15/7_strategy4.html.

3. Sovremennaya demograficheskaya situatsiya v strane. Analiticheskiy material Federal'noy sluzhby gosudarstvennoy statistiki [The present demographic situation in the country. Analytical data of the Federal State Statistics Service]. Available at: http://www.gks.ru/wps/wcm/connect/rosstat/rosstatsite/main/population/demography/.

4. O sostoyanii sanitarno-epidemiologicheskogo blagopoluchiya naseleniya v Rossiyskoy Federatsii v 2011 godu. Gosudarstvennyy doklad [On the condition of health and epidemiological well-being of the population in the Russian Federation in 2011. A state report]. Moscow: Federal'nyy tsentr gigieny i epidemiologii Rospotrebnadzora, 2012. 323 p.

5. Onishchenko G.G. Osnovnye itogi i perspektivy obespecheniya sanitarno-epidemiologicheskogo blagopoluchiya naseleniya [The main results and prospects of ensuring health and epidemiological well-being]. Materialy KhI Vserossiyskogo s"ezda gigienistov $i$ sanitarnykh vrachey. Ed. akad RAMN G.G. Onishchenko, akad RAMN prof. A.I. Potapov. Moscow, Yaroslavl: Kantsler, 2012, pp. 30-40.

6. Potapov A.I., Rakitskiy V.N. Problemy sovremennoy gigieny [Issues of modern hygiene]. Materialy KhI Vserossiyskogo s"ezda gigienistov $i$ sanitarnykh vrachey. Ed. akad RAMN G.G. Onishchenko, akad RAMN prof. A.I. Potapov. Moscow, Yaroslavl: Kantsler, 2012, pp. 40-49.

7. Izmerov N.F., Denisov E.I., Morozova T.V. Okhrana zdorov'ya rabotnikov: garmonizatsiya terminologii, zakonodatel'stva i praktiki s mezhdunarodnymi standartami [Workers' health protection: the harmonization of terminology, legislation and practice with international standards]. Meditsina truda i promyshlennaya ekologiya, 2012, no. 8, pp. 1-7.

8. Zajceva N.V., Shur P.Z., Maj I.V., Sboev A.S., Volk-Leonovich O.L., Nurislamova T.V. Kompleksnye voprosy upravlenija riskom zdorov'ju v reshenii zadach obespechenija sanitarno-jepidemiologicheskogo blagopoluchija na municipal'nom urovne [Complex issues of health risk management in solving the problems of sanitary-andepidemic well-being provision at the municipal level]. Gigiena i sanitarija, 2007, no. 5, pp. 16-18.

9. Kuz'min S.V., Gurvich V.B., Jarushin S.V., Malyh O.V., Romanov S.V., E.A. Kuz'mina, Voronin S.A., Kochneva N.I. Sistema upravlenija sanitarno-jepidemiologicheskoj obstanovkoj $s$ ispol'zovaniem social'nogigienicheskogo monitoringa i metodologii ocenki riska dlja zdorov'ja naselenija [System of management sanitary-epidemiological situation using the social-hygienic monitoring and methodology of health risk assessment]. Materialy nauchno-prakticheskoj konferencii «Gigienicheskie i metodiko-profilakticheskie tehnologii upravlenija riskami zdorov'ju naselenija v promyshlenno razvityh regionah», Perm, 6-8 oktober, 2010. Ed. Akademik RAMN G.G. Onishhenko, chlen-korrespondent RAMN N.V. Zajceva. Perm, 2010, pp. 73-78.

10. Maj I.V., Horoshavin V.A., Evdoshenko V.S. Algoritm i metody sanitarno-jepidemiologicheskogo rassledovanija narushenij prav grazhdan na okruzhajushhuju sredu s jetapom ocenki riska dlja zdorov'ja [Algorithms and 
methods of sanitary-epidemiological investigation of civil rights violation on a favorable habitats with step of health risk assessment]. Zdorov'e naselenija i sreda obitanija, 2010, no. 11, pp. 28-30.

11. Onishchenko G.G. Organizatsiya nadzora za oborotom materialov, predstavlyayushchikh potentsial'nuyu opasnost' dlya zdorov'ya cheloveka [The organization of surveillance of the turnover of materials which are potentially hazardous to human health]. Gigiena $i$ sanitariya, 2011, no. 2, pp. 4-9.

\title{
HEALTH RISK ASSESSMENT AND MANAGEMENT AS AN EFFECTIVE TOOL TO SOLVE ISSUES TO ENSURE THE HEALTH AND EPIDEMIOLOGICAL WELL-BEING OF THE RUSSIAN FEDERATION POPULATION
}

\section{G.G. Onischenko}

\begin{abstract}
Federal Service on Customers' Rights Protection and Human Well-Being Surveillance, Russian Federation, building 5 and 7, house 18, Vadkovsky lane, Moscow, 127994
\end{abstract}

The Russian Federation continues to develop legislative, scientific, methodological and information bases, harmonized with international requirements and approaches, for the methodology of assessing health risks from exposure to harmful environmental factors. Health risk assessment methods, which are included in the social and environmental health monitoring system, have been validated and proven to be effective, are used in many Russian regions to justify health and environmental measures to protect public health, workers' health as well as in product safety analysis, etc. Taking into account risk parameters, we developed national environmental health standards of the concentrations of chemical substances in the environment, we justified the position of the Russian Federation on the content of residual harmful impurities in food, we justified ambient air quality monitoring programs during the Universiade in Kazan and the Olympic Games in Sochi. The country is developing methodical and laboratory basis for social and environment health monitoring as a foundation for exposure assessment; new approaches to the determination and mathematical modeling of "dose-effect" relationships, to risk classifications, including those used in exposure to factors of various origin, and to the application of risk assessment results in management decision making in the field of ensuring health and epidemiological well-being, are being validated.

Keywords: risk assessment, risk management, practical application.

(C) Onischenko G.G., 2013

Onishchenko Gennady Grigoryevich - Fellow of the Russian Academy of Medical Sciences, DSc, professor; Director (e-mail: depart@gsen.ru,tel.: +7 (499) 973-26-90). 
УДК 51-76,613

\title{
МЕТОДИЧЕСКИЕ ПОДХОДЫ К ОЦЕНКЕ РИСКА ВОЗДЕЙСТВИЯ РАЗНОРОДНЫХ ФАКТОРОВ СРЕДЫ ОБИТАНИЯ НА ЗДОРОВЬЕ НАСЕЛЕНИЯ НА ОСНОВЕ ЭВОЛЮЦИОННЫХ МОДЕЛЕЙ
}

\author{
Н.В. Зайцева 1 , П.В. Трусов², П.3. Шур¹, Д.А. Кирьянов ${ }^{1}$, \\ В.М. Чигвинцев ${ }^{1}$, М.Ю. Цинкер ${ }^{1}$ \\ 1 Федеральный научный центр медико-профилактических технологий управления \\ рисками здоровью населения, Россия, 614045, г. Пермь, ул. Монастырская, 82 , \\ 2 Пермский национальный исследовательский политехнический университет, \\ Россия, 614990, г. Пермь, Комсомольский просп., 29
}

Рассматриваются методические подходы к оценке риска здоровью населения при сочетанном воздействии факторов среды обитания. Апробация методических подходов показала, что с их помощью может быть произведен расчет показателей индивидуального и популяционного риска, прогнозируемой продолжительности жизни, классифицирован уровень риска в соответствии с предложенной шкалой. Установлено, что при экспозиции комплекса химических факторов загрязнения атмосферного воздуха, транспортного шума, негативных факторов образа жизни неприемлемый (умеренный) риск здоровью формируется к возрасту 47 лет, высокий - к 58 годам. Максимальный вклад в формирование риска вносят факторы образа жизни - употребление алкоголя, курение, недостаточная двигательная активность. Прогнозируемая продолжительность жизни сокращается на 12,3 года.

Ключевые слова: оценка риска здоровью, эволюция риска, интегральный риск, прогнозируемая продолжительность жизни, факторы среды обитания.

Современная санитарно-эпидемиологическая ситуация характеризуется сочетанным воздействием разнородных факторов среды обитания на здоровье населения. К ним относятся биологические, химические, физические, социальные и иные факторы среды обитания, которые оказывают или могут оказывать воздействие на человека и (или) на состояние здоровья будущих поколений [1]. В этих условиях существующие способы оценки риска здоровью населения, связанного с отдельными факторами и даже группами факторов, могут применяться только для решения локальных задач обеспечения санитарно-эпидемиологического благополучия. В этой связи проблема оценки риска разнородных факторов среды обитания при их одновременном воздействии является актуальной. При этом оправдано применение методических подходов, с одной стороны, использующих уже имеющуюся

() Зайцева Н.В., Трусов П.В., Шур П.З., Кирьянов Д.А., Чигвинцев В.М., Цинкер М.Ю., 2013

Зайцева Нина Владимировна - академик РАМН, доктор медицинских наук, профессор; директор (е-mail: znv@fcrisk.ru, root@fcrisk.ru, тел.: 8 (342) 237-25-34).

Трусов Петр Валентинович - доктор физико-математических наук, профессор; заведующий кафедрой математического моделирования систем и процессов (e-mail: tpv@ matmod.pstu.ac.ru, тел.: 8 (342) 239-16-07).

Шур Павел Залманович - доктор медицинских наук, профессор, ученый секретарь, заведующий отделом анализа риска для здоровья (e-mail: shur@ fcrisk.ru, тел.: 8 (342) 238-33-37).

Кирьянов Дмитрий Александрович - кандидат технических наук, заведующий отделом математического моделирования систем и процессов (e-mail: kda@fcrisk.ru, kir-da2010@ rambler.ru, тел.: 8 (342) 237-18-04).

Чигвинцев Владимир Михайлович - научный сотрудник отдела математического моделирования систем и процессов (e-mail: cvm@fcrisk.ru, тел.: 8 (342) 237-18-04).

Цинкер Михаил Юрьевич - младший сотрудник отдела математического моделирования систем и процессов (e-mail: cinker@fcrisk.ru, тел.: 8 (342) 237-18-04). 
информацию о причинно-следственных связях показателей здоровья населения с экспозицией отдельных факторов, с другой - предполагающих применение комплекса современных научных способов обработки накопленных данных.

Одним из них является моделирование эволюции риска, предполагающее скоординированное применение статистических и аналитических моделей, которое можно рассматривать как один из наиболее адекватных методов для решения задач прогнозирования и оценки вероятного воздействия факторов среды обитания на здоровье населения.

Моделирование негативных трансформаций функций организма человека позволяет более полно учитывать эффекты, обусловленные экспозицией разнородных факторов, в том числе на фоне возрастных изменений. Эволюционные модели дают возможность при заданных сценариях экспозиции в течение всей жизни человека оценивать риск появления нарушений функций отдельных органов и систем, анализировать вклад отдельных факторов и/или их сочетаний в формирование риска здоровью [2, 3]. Подобные аналитические подходы, развивающие методологию оценки риска здоровью, позволяют проводить численные (виртуальные) эксперименты, трудно воспроизводимые в реальных условиях, и оценивать риск возникновения негативных эффектов при заданных сценариях экспозиции, сочетающих условия селитебной зоны, производственной среды, питания, образа жизни и пр.

В соответствии с концептуальными положениями моделирования эволюции риска здоровью организм представляется как открытая система, которая непрерывно взаимодействует с окружающей средой и состоит из конечного множества органовмишеней, полностью взаимосвязанных друг с другом [4]. Негативное воздействие разнородных факторов среды обитания может проявляться в виде нарушения функций органов и систем организма человека. При этом могут рассматриваться процессы как восстановления функций при отсутствии повреждающего воздействия, так и накопления функциональных нарушений. Посколь- ку разнородные факторы среды обитания могут оказывать влияние на одни и те же функции организма человека, применение моделирования эволюции риска здоровью для задач его оценки представляется наиболее адекватным [5].

Эволюция риска негативных эффектов описывается системой дифференциальных уравнений, которая отражает накопление функциональных нарушений, связанных с повреждающим действием факторов среды обитания на фоне естественных процессов, протекающих в организме.

$$
\begin{gathered}
\frac{d R^{i}}{d t}=\alpha_{i} R^{i}-\beta_{i}\left(1-R^{i}\right)^{n}+\sum_{k} \gamma_{k i} f_{k i}\left(F_{k}\right), \\
i=\overline{1, r},
\end{gathered}
$$

где $R^{i}$ - риск появления нарушений $i$-й системы организма; $\alpha_{i}-$ коэффициент, учитывающий эволюцию риска за счет естественных причин; $\beta_{i}-$ коэффициент, учитывающий интенсивность процессов самовосстановления функций органов и систем организма; $\gamma_{k i} f_{k i}\left(F_{k}\right)$ - слагаемое, отражающее интенсивность накопления риска возникновения нарушений функционального состояния $i$-й системы, связанного с экспозицией $k$-го фактора.

Для решения данной системы уравнений наиболее адекватен метод приближенных вычислений на основе явной конечноразностной схемы. Представление эволюционной модели (1) в виде рекуррентных соотношений позволяет применить итерационную расчетную процедуру по временным шагам:

$$
R_{t+1}^{i}=R_{t}^{i}+\left(\alpha_{i} R_{t}^{i}+\sum_{k} \Delta R_{t}^{i k}\right) C,
$$

где $R_{t+1}^{i}-$ риск появления нарушений $i$-й системы организма в момент времени $t+1$; $R_{t}^{i}-$ риск позникновения нарушений $i$-й системы организма в момент времени $t ; \alpha_{i}-$ коэффициент, учитывающий эволюцию риска за счет естественных причин; $\Delta R_{t}^{i k}-$ прирост риска появления нарушений $i$-й системы организма, обусловленный действием экспо- 
зиции $k$-го фактора в момент времени $t$; $C$ - эмпирический коэффициент пересчета для различных периодов осреднения (для среднегодовых экспозиций $C=1$, для среднемесячных $C=0,083$, для среднесуточных $C=0,0027)$.

Применение методов моделирования эволюции риска позволяет подойти к оценке интегрального риска здоровью, который представляет собой риск развития негативных эффектов различной тяжести в результате одновременного воздействия на человека группы факторов разной природы. Оценку интегрального риска здоровью следует рассматривать как компонент интегрированной оценки риска, не затрагивающий оценку риска для экологических систем.

В соответствии в международно принятой методологией оценки риска здоровью оценка интегрального риска предполагает последовательное проведение следующих этапов: идентификация опасности, выбор зависимости «экспозиция - эффект», оценка экспозиции и характеристика риска.

Идентификация опасности включает идентификацию факторов среды обитания, потенциально воздействующих на здоровье человека, возможных эффектов воздействия этих факторов, механизмов негативного воздействия на здоровье человека, контингентов риска. На этом этапе принимается решение о необходимости проведения процедуры оценки интегрального риска в каждом конкретном случае.

В ходе оценки экспозиции устанавливаются количественные параметры интенсивности и продолжительности воздействия факторов среды обитания на здоровье, формирование детальных сценариев экспозиции факторов среды обитания, в том числе с учетом вида оцениваемого воздействия (однократное, хроническое, интермиттирующее и пр.).

На этапе выбора зависимости «экспозиция - эффект» производится анализ имеющихся параметров в виде математических моделей и эпидемиологических показателей, характеризующих связи экспози- ции отдельных факторов риска и эффектов их воздействия на здоровье. С учетом этих параметров осуществляется разработка определяющих соотношений, необходимых для расчета интегрального риска. Развитие методологии на этапе выбора зависимости «экспозиция - эффект» предполагает проведение моделирования риска в соответствии с выбранными сценариями (имитационное моделирование).

Характеристика риска включает расчет величин дополнительного интегрального риска здоровью, связанного с влиянием совокупности изучаемых факторов, приведенного индекса риска здоровью, сокращения прогнозируемой продолжительности жизни в условиях многофакторного воздействия и прогноз популяционных показателей риска здоровью в виде ожидаемого риска заболеваний и смерти в изучаемой популяции.

Дополнительный риск различных нарушений здоровья, связанный с неблагоприятным действием отдельных факторов среды обитания, рассчитывается по формуле

$$
\Delta R_{t}=R_{t}-R_{t}^{\phi},
$$

где $\Delta R_{t}$ - дополнительный риск различных нарушений здоровья в момент времени $t$.

В общем виде кривая изменения риска нарушений здоровья в зависимости от длительности и условий экспозиции без воздействия и в условиях вредного воздействия факторов среды обитания, а также величина дополнительного риска приведены на рис. 1.

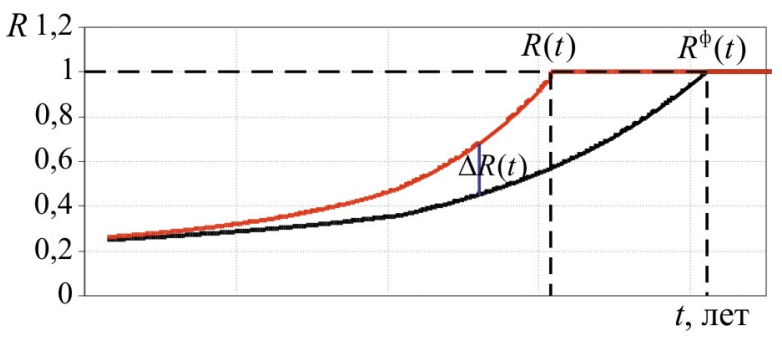

Рис. 1. Эволюция риска и дополнительного риска появления вредных эффектов при воздействии факторов среды обитания 
Для оценки уровня риска рассчитывается приведенный индекс риска здоровью, связанный с воздействием факторов:

$$
\tilde{R}_{t}=\frac{\Delta R_{t}}{1-R_{t}^{\phi}} .
$$

Приведенный индекс риска характеризует вероятность нарушений здоровья при воздействии факторов среды обитания с учетом нарастания общего риска здоровью по мере увеличения продолжительности экспозиции.

Оценка величин интегрального риска здоровью производится с использованием шкалы, представленной в табл. 1.

\section{Таблица 1}

Шкала для оценки интегрального риска

\begin{tabular}{|c|c|}
\hline $\begin{array}{c}\text { Оценочный индекс } \\
\text { риска }\end{array}$ & $\begin{array}{c}\text { Характеристика } \\
\text { риска }\end{array}$ \\
\hline $0-0,1$ & Пренебрежимо малый \\
\hline $0,1-0,35$ & Умеренный \\
\hline $0,35-0,6$ & Высокий \\
\hline $0,6-1$ & Очень высокий \\
\hline
\end{tabular}

Сокращение продолжительности жизни $(\Delta T$, лет), связанное с вредным воздействием факторов среды обитания, рассчитывается следующим образом:

$$
\Delta T=T_{0}-T_{1},
$$

где $T_{0}$ - прогнозируемая продолжительность жизни без воздействия факторов, полученная в результате пошагового расчета без учета действия факторов, лет; $T_{1}-$ прогнозируемая продолжительность жизни при вредном воздействии факторов, полученная в результате пошагового расчета, лет.

Апробация предложенных методических подходов поведена на примере модельного сценария, сформированного по результатам наблюдений за качеством объектов среды обитания в рамках социальногигиенического мониторинга, дополненного результатами социологических исследований факторов образа жизни в крупном промышленном городском поселении в Российской Федерации. В соответствии со сценарием оценивалось интегральное воздей- ствие химических (оксид углерода, диоксид азота, взвешенные вещества $\mathrm{PM}_{2,5}$, взвешенные вещества $\mathrm{PM}_{10}$, свинец, кадмий) веществ, поступающих из атмосферного воздуха, физических факторов риска (транспортный шум) и факторов образа жизни (курение, употребление алкоголя, физическая активность) (табл. 2).

Таблица 2

Диапазон значений уровня экспозиции

\begin{tabular}{|c|c|c|}
\hline Фактор & $\begin{array}{l}\text { Параметры } \\
\text { факторов }\end{array}$ & $\begin{array}{c}\text { Допустимый } \\
\text { (референтный) } \\
\text { уровень }\end{array}$ \\
\hline \multicolumn{3}{|c|}{$\begin{array}{c}\text { Вещества, поступающие из атмосферного } \\
\text { воздуха, мг/м }{ }^{3}\end{array}$} \\
\hline Диоксид азота & $0,022-0,127$ & 0,04 \\
\hline Оксид углерода & $3,5-5,33$ & 3,0 \\
\hline $\begin{array}{l}\text { Взвешенные вещества } \\
\mathrm{PM}_{2,5}\end{array}$ & $0,034-0,043$ & 0,025 \\
\hline $\begin{array}{l}\text { Взвешенные вещества } \\
\text { PM }_{10}\end{array}$ & $0,052-0,075$ & 0,04 \\
\hline Свинец & $\begin{array}{c}0,000874- \\
0,000929\end{array}$ & 0,0005 \\
\hline Кадмий & $\begin{array}{c}0,00038- \\
0,00041\end{array}$ & 0,00002 \\
\hline \multicolumn{3}{|c|}{ Физические факторы воздействия } \\
\hline Шум, дБА & 55,72 & 50 \\
\hline \multicolumn{3}{|c|}{ Социальные факторы и факторы образа жизни } \\
\hline $\begin{array}{l}\text { Курение, мг никоти- } \\
\text { на/сут. }\end{array}$ & $0-10$ & 0,1 \\
\hline $\begin{array}{l}\text { Употребление алкого- } \\
\text { ля, г/нед. }\end{array}$ & $0-50$ & 30 \\
\hline $\begin{array}{l}\text { Физическая актив- } \\
\text { ность, мин/нед. }\end{array}$ & $200-60$ & Не менее 200 \\
\hline
\end{tabular}
факторов среды обитания

Оценка временного распределения уровня транспортного шума в соответствии с результатами анализа хронологии и длительности шумовых событий на изучаемой территории показала, что эта величина характеризуется стабильностью и может рассматриваться как постоянно действующая нагрузка, соответствующая уровню эквивалентного шума 55,72 дБА.

В отношении факторов образа жизни установлены уровни, соответствующие возрастным диапазонам. Пожизненное распределение экспозиции факторов образа жизни представлено на рис. 2.

Для экстраполяции данных трехлетних мониторинговых наблюдений за качеством атмосферного воздуха на условия пожиз- 

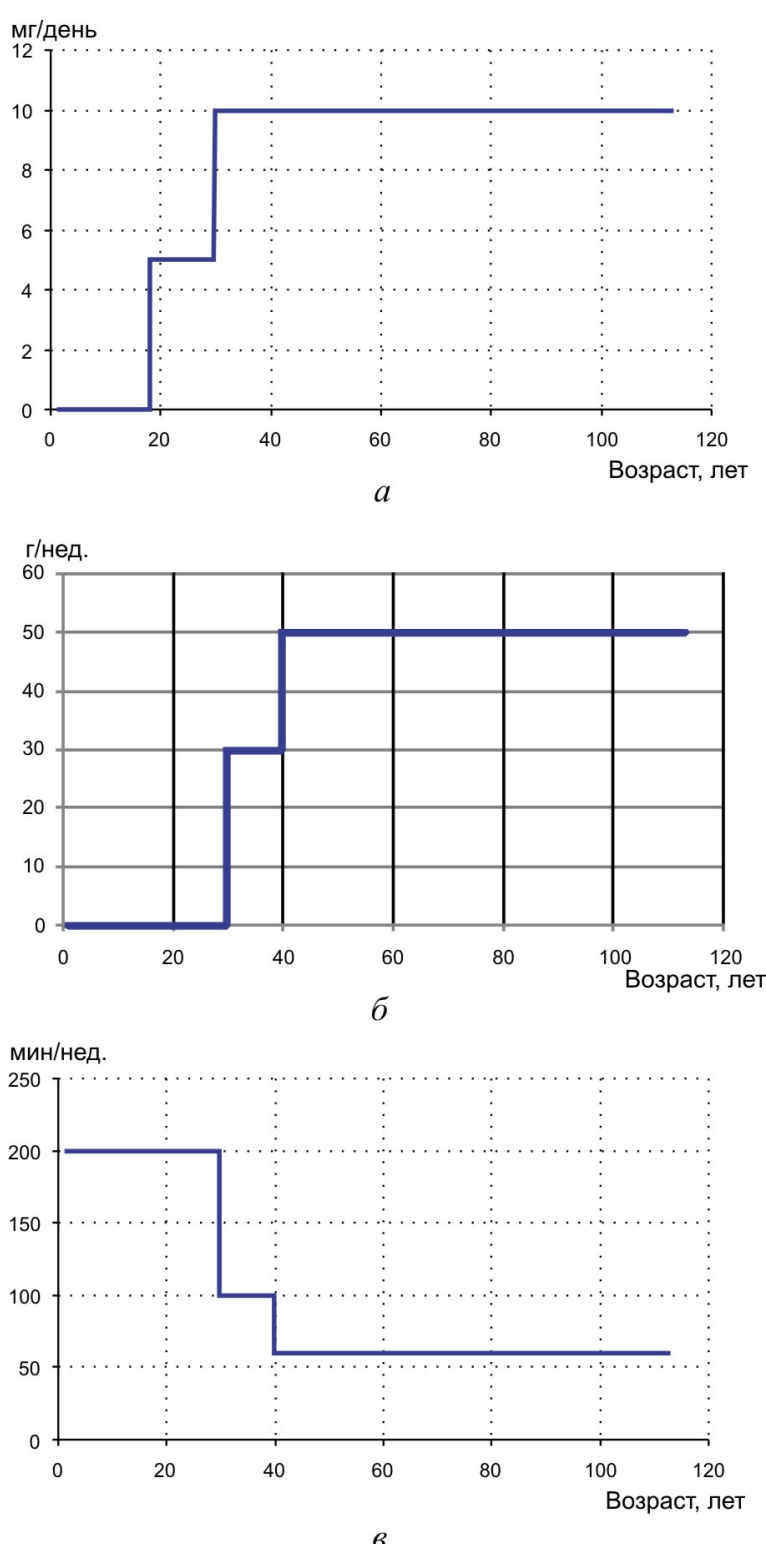

Рис. 2. Временное распределение факторов образа жизни: $a$ - употребление никотина; б - употребление алкоголя; $в$ - двигательная активность

ненной экспозиции установлены динамические закономерности изменения среднемесячных концентраций, определены параметры гармонической модели и выполнен расчет прогнозных оценок (рис. 3).

В качестве фоновых условий экспозиции принимали допустимые величины воздействия на уровне референтных концентраций химических веществ в атмосферном воздухе, предельно допустимого уровня шума и рекомендуемых безвредных параметров образа жизни.
Расчет интегрального риска проводился на основе реализации системы рекуррентных уравнений в виде программного модуля, выполненного в MS Excel. В результате получены эволюционные детерминированные модели риска при двух сценариях (фонового и исследуемого) (рис. 4).

Расчет с использованием полученных моделей показателей дополнительного риска и приведенного индекса риска позволил установить, что при рассматриваемом сценарии воздействия неприемлемый (умеренный) риск здоровью формируется к возрасту 47 лет, а к 58 годам этот риск может быть охарактеризован как высокий (табл. 3).

Анализ структуры интегрального риска для данного сценария экспозиции показал, что наиболее значимыми факторами риска являются употребление алкоголя и шумовое загрязнение, которые формируют наибольший дополнительный интегральный риск для здоровья к 60 годам. Далее по степени опасности факторов риска расположились курение, снижение двигательной активности, загрязнение воздуха диоксидом азота и кадмием.

Дополнительный интегральный риск обусловлен в основном воздействием анализируемых факторов на сердечно-сосудистую систему, а также, в меньшей степени, на органы дыхания, эндокринную и пищеварительную системы.

Максимальный вклад в формирование риска вносят факторы образа жизни - употребление алкоголя, курение, недостаточная двигательная активность (рис. 5).

Показатели интегрального популяционного риска здоровью, рассчитанные в соответствии с разработанными методическими подходами [6], свидетельствуют о возможном увеличении заболеваемости населения к 60 годам болезнями системы кровообращения (до $577 \%$ ), органов пищеварения (до $234 \%$ ), дыхания (до $73 \%$ \%). Уровни дополнительной смертности по причине указанных заболеваний могут составить соответственно 6, 1 и 0,3\%о. В качестве дополнительной характеристики интегрального популяционного риска использована величина сокращения прогнозируемой 

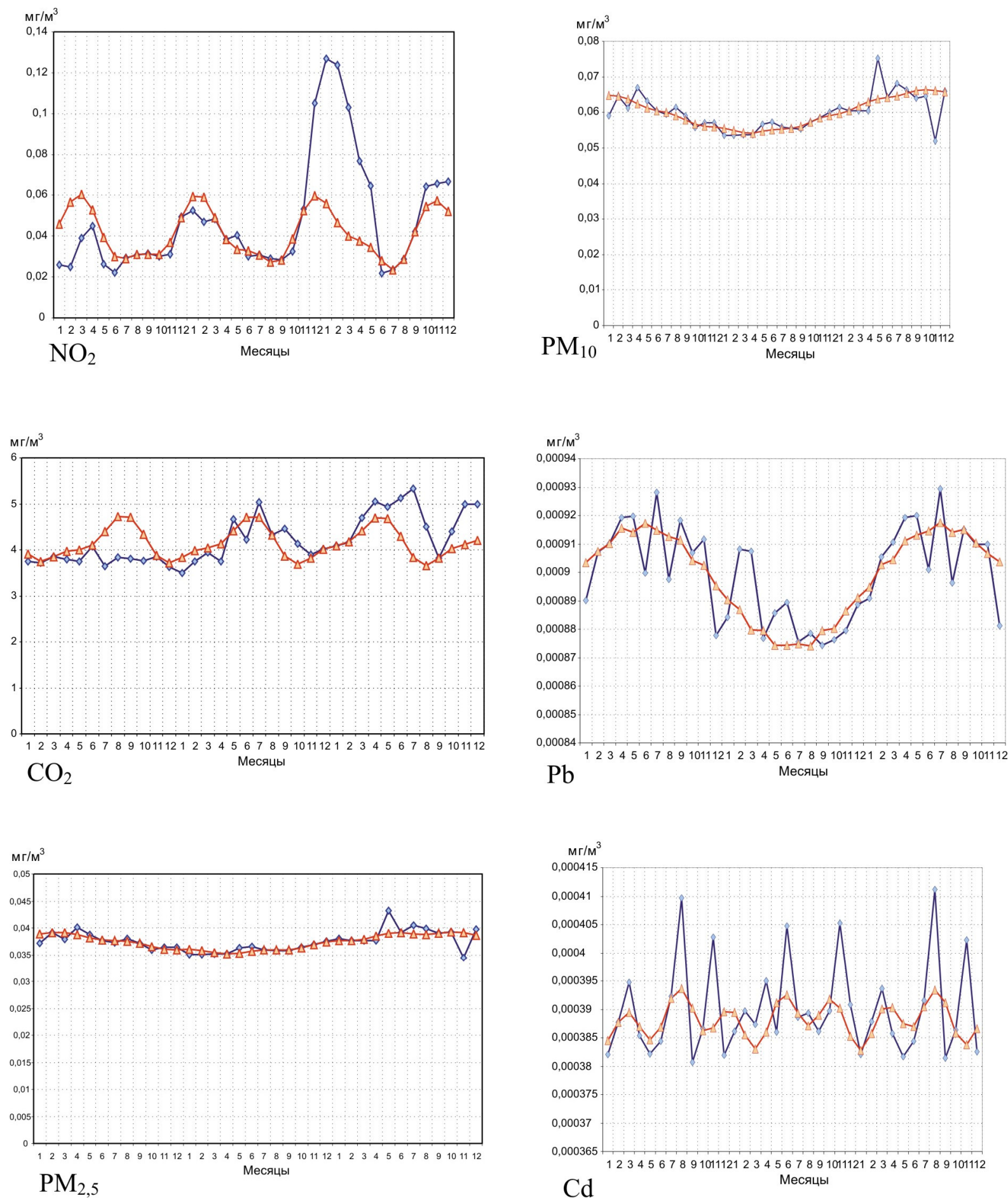

Рис. 3. Аппроксимация динамики концентраций химических веществ в атмосферном воздухе 
Таблица 3

Результаты расчетов интегрального риска здоровью

\begin{tabular}{|c|c|c|c|}
\hline Возраст, лет & Интегральный риск & Приведенный индекс риска & Характеристика риска \\
\hline 10 & 0,0206 & 0,0010 & Пренебрежимо малый \\
\hline 20 & 0,0377 & 0,0044 & Пренебрежимо малый \\
\hline 40 & 0,1005 & 0,0418 & Пренебрежимо малый \\
\hline 50 & 0,2228 & 0,1383 & Умеренный \\
\hline 60 & 0,5227 & 0,3924 & Высокий \\
\hline
\end{tabular}

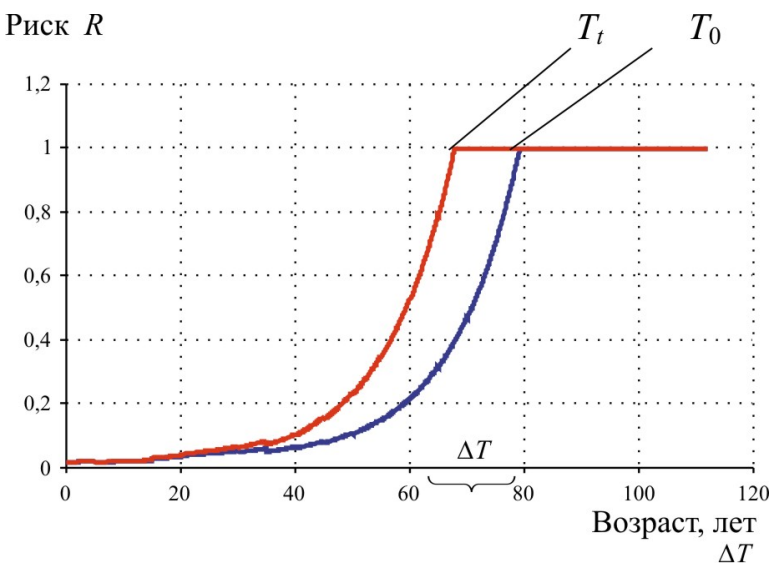

Рис. 4. Эволюционные детерминированные модели риска при двух сценариях (результаты расчетов)

продолжительности жизни, связанная с интегральным негативным воздействием факторов среды обитания. Для данного сценария эта величина составит в исследуемой популяции в среднем 12,3 г.

\section{Выводы:}

1. Моделирование эволюции риска является адекватным методом для оценки воздействия разнородных факторов среды обитания на здоровье населения, позволяющим количественно оценивать показатели индивидуального и популяционного риска, в том числе сокращение прогнозируемой продолжительности жизни.

2. Методические подходы к оценке риска воздействия разнородных факторов среды обитания позволяют оценивать его категории в соответствии с предложенной шкалой и моделировать изменение риска нарушения функций органов и систем организма человека в течение жизни.

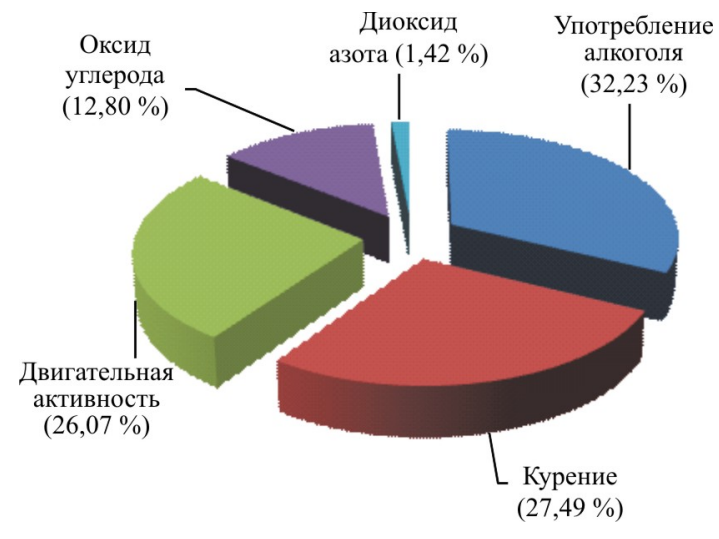

Рис. 5. Вклад разнородных факторов среды обитания в формирование интегрального риска здоровью при исследуемом сценарии экспозиции

3. В ходе апробации предложенных методических подходов на примере модельного сценария экспозиции показано, что сочетанное воздействие разнородных факторов среды обитания (загрязнение атмосферного воздуха, шум, употребление алкоголя, курение, недостаточная двигательная активность) может привести к формированию неприемлемого риска здоровью к возрасту 47 лет, а к 58 годам этот риск может быть охарактеризован как высокий.

4. Характеристика интегрального популяционного риска здоровью для исследуемого сценария свидетельствует о возможном увеличении заболеваемости населения к 60 годам болезнями системы кровообращения, пищеварения, дыхания. Уровни дополнительной смертности по причине указанных заболеваний могут составить соответственно 6, 1 и 0,3 \%о, что приведет к сокращению прогнозируемой продолжительности жизни в среднем на 12,3 г. 


\section{Список литературы}

1. О санитарно-эпидемиологическом благополучии населения: Федеральный закон от 30 марта 1999 г. № 52-Ф3 [Электронный ресурс]. - URL: http://files.stroyinf.ru/Data1/6/6000/ (дата обращения: 20.12.2012).

2. Методические подходы к оценке интегрального риска здоровью населения на основе эволюционных математических моделей / Н.В. Зайцева, П.З. Шур, И.В. Май, Д.А. Кирьянов // Здоровье населения и среда обитания. - 2011. - № 10. - С. 69.

3. Зайцева Н.В., Трусов П.В., Кирьянов Д.А. Концептуальная математическая модель накопления нарушений функций организма, ассоциированных с факторами среды обитания // Медицина труда и промышленная экология. - 2012. - № 12. - С. 40-45.

4. Математическая модель эволюции функциональных нарушений в организме человека с учетом внешнесредовых факторов / П.В. Трусов, Н.В. Зайцева, Д.А. Кирьянов, М.Р. Камалтдинов, М.Ю. Цинкер, В.М. Чигвинцев, Д.В. Ланин [Электронный ресурс] // Математическое моделирование и биоинформатика. 2012. - № 2. - С. 589-610. - URL: http://www.matbio.org/2012/Trusov_7_589.pdf (дата обращения: 05.12.2012).

5. Кирьянов Д.А., Сухарева Т.Н. Метод построения интегрального индекса функционального состояния мочевыделительной системы // Гигиенические и медико-профилактические технологии управления рисками здоровью населения в промышленно развитых регионах: материалы науч.-практ. конф. с международным участием / под общ. ред. Г.Г. Онищенко, Н.В. Зайцевой. - Пермь: Книжный формат, 2010. - 638 с.

6. Методические подходы к оценке популяционного риска здоровью на основе эволюционных моделей / Н.В. Зайцева, П.З. Шур, Д.А. Кирьянов, М.Р. Камалтдинов, М.Ю. Цинкер // Здоровье населения и среда обитания. - 2013. - № 1. - С. 4-6.

\section{References}

1. O sanitarno-epidemiologicheskom blagopoluchii naseleniya: Federal'nyy zakon ot 30 marta 1999 g. [On Health and Epidemiological Well-Being of the Population: the federal law as of March 30, 1999. № 52-FZ]. Available at: http: //files.stroyinf.ru/Data1/6/6000/.

2. Zaytseva N.V., Shur P.Z., May I.V., Kir'yanov D.A. Metodicheskie podkhody k otsenke integral'nogo riska zdorov'yu naseleniya na osnove evolyutsionnykh matematicheskikh modeley [Methodological approaches to integral health risk assessment based on mathematical evolutionary models]. Zdorov'e naseleniya $i$ sreda obitaniya, 2011, no. 10. pp. 6-9.

3. Zaytseva N.V., Trusov P.V., Kir'yanov D.A. Kontseptual'naya matematicheskaya model' nakopleniya narusheniy funktsiy organizma, assotsiirovannykh s faktorami sredy obitaniya [A conceptual mathematical model of the accumulation of disorders in the body functions associated with environmental factors]. Meditsina truda i promyshlennaya ekologiya, 2012, no. 12, pp. 40-45.

4. Trusov P.V., Zaytseva N.V., Kir'yanov D.A., Kamaltdinov M.R., Tsinker M.Yu., Chigvintsev V.M., Lanin D.V. Matematicheskaya model' evolyutsii funktsional'nykh narusheniy $\mathrm{v}$ organizme cheloveka s uchetom vneshnesredovykh faktorov [A mathematical model of the evolution of functional disorders in the human body, taking into account environmental factors]. Matematicheskoe modelirovanie i bioinformatika, 2012, no. 2, pp. 589-610.

5. Kir'yanov D.A., Sukhareva T.N. Metod postroeniya integral'nogo indeksa funktsional'nogo sostoyaniya mochevydelitel'noy sistemy [A method for constructing the integral index of the functional condition of the urinary system]. Gigienicheskie $i$ mediko-profilakticheskie tekhnologii upravleniya riskami zdorov'yu naseleniya $v$ promyshlenno razvitykh regionakh: materialy nauchno-prakticheskoy konferentsii s mezhdunarodnym uchastiem. Ed. G.G. Onishchenko, N.V. Zaytseva. Perm: Knizhnyy format, 2010. 638 p.

6. Zaytseva N.V., Shur P.Z., Kir'yanov D.A., Kamaltdinov M.R., Tsinker M.Yu. Metodicheskie podkhody k otsenke populyatsionnogo riska zdorov'yu na osnove evolyutsionnykh modeley [Methodological approaches to population health risk assessment based on evolutionary models]. Zdorov'e naseleniya i sreda obitaniya, 2013, no. 1, pp. 4-6. 


\title{
METHODICAL APPROACHES TO HEALTH RISK ASSESSMENT OF HETEROGENEOUS ENVIRONMENTAL FACTORS BASED ON EVOLUTIONARY MODELS
}

\author{
N.V. Zaitseva1, P.V. Trusov'2, P.Z. Shur¹, D.A. Kiryanov'1, \\ V.M. Chigvintsev' ${ }^{1}$, M.Yu. Tsinker ${ }^{1}$ \\ ${ }^{1}$ Federal Scientific Center for Medical and Preventive Health Risk, Russian Federation, \\ 82 Monastyrskya St., Perm, 614045 \\ 2 Perm National Research Polytechnic University, Russian Federation, \\ 29 Komsomolskiy prospect, Perm, 614990
}

In this article, we consider methodical approaches to health risk assessment of a combined impact of environmental factors. The validation of the methodological approaches showed that they can be used to calculate the indicators of individual and population risk, life expectancy and to classify risk level in accordance with the proposed scale. We determined that individuals exposed to a complex of chemical factors of ambient air pollution, traffic noise and negative lifestyle factors develop an unacceptable (moderate) health risk by the age of 47 and a high health risk by the age of 58. The maximum contribution to the risk development is made by lifestyle factors - alcohol consumption, smoking, lack of physical activity. Life expectancy reduces by 12.3 years.

Keywords: health risk assessment, evolution of risk, integral risk, life expectancy, environmental factors.

C) Zaitseva N.V., Trusov P.V., Shur P.Z., Kiryanov D.A., Chigvintsev V.M., Tsinker M.Yu., 2013

Zaitseva Nina Vladimirovna - Fellow of the Russian Academy of Medical Sciences, DSc, Professor, Center Director (tel/fax: 8 (342) 237-25-34, e-mail: znv@fcrisk.ru, root@fcrisk.ru).

Trusov Petr Valentinovich - DSc, professor, Head of Department of Systems and Processes Mathematical Modeling (tel.: 8 (342) 239-16-07, e-mail: tpv@ matmod.pstu.ac.ru).

Shur Pavel Zalmanovich - DSc, professor, Secretary of the Academic Council, Head of Health Risk Analysis Department of Federal Scientific Center for Medical and Preventive Health Risk Management Technologies (e-mail: shur@fcrisk.ru, tel/fax: 8 (342) 237-25-34, 8 (342) 238-33-37).

Kiryanov Dmitry Alexandrovich - PhD in Engineering, Head of Department of Systems and Processes Mathematical Modeling Federal Scientific Center for Medical and Preventive Health Risk Management Technologies (e-mail: kda@fcrisk.ru, kir-da2010@ rambler.ru, tel.: 8 (342) 237-18-04).

Chigventsev Vladimir Michaylovich - fellow research of Department of Systems and Processes Mathematical Modeling Federal Scientific Center for Medical and Preventive Health Risk Management Technologies (e-mail: cvm@fcrisk.ru, tel.: 8 (342) 237-18-04).

Cinker Michail Yur'evich - Junior research fellow of Department of Systems and Processes Mathematical Modeling Federal Scientific Center for Medical and Preventive Health Risk Management Technologies (e-mail: cinker@fcrisk.ru, tel.: 8 (342) 237-18-04). 
УДК 613. 636

\title{
ОСОБЕННОСТИ АНАЛИЗА РИСКА ЗДОРОВЬЮ ПРИ РАБОТЕ С ПАТОГЕННЫМИ БИОЛОГИЧЕСКИМИ АГЕНТАМИ
}

\author{
О.Н. Доброхотский', А.И. Дятлов² \\ 1 Медико-санитарная часть № 164 Федерального медико-биологического агентства, \\ Россия, 142279, Московская область, Серпуховский район, п. Оболенск, \\ 2 Государственный научный центр прикладной микробиологии и биотехнологии Роспотребнадзора, \\ Россия, 142279, Московская область, Серпуховский район, п. Оболенск
}

Вопросы биологической безопасности приобретают особую актуальность и являются приоритетными в обеспечении национальной безопасности РФ. В работе намечены пути по разработке методического подхода по управлению биорисками при работе с патогенными биологическими агентами (ПБА) с целью минимизации рисков внутрилабораторных заражений. Показано, что разработка и внедрение методологии управления биорисками при работе с ПБА будет являться основой для разработки и принятия управленческих решений, повышающих эффективность действующей системы биобезопасности.

Ключевые слова: оценка и управление биорисками, патогенные биологические агенты, внутрилабораторное заражение персонала.

Государственная система биологической безопасности является важной составной частью системы национальной безопасности и представляет собой систему организационных и технических мер, направленных на предотвращение ущерба и достижение защищенности личности, общества и государства от потенциальных и реальных биологических угроз.

В настоящее время вопросы биологической безопасности на территории Российской Федерации приобретают особую актуальность и являются приоритетными в обеспечении национальной безопасности [3].

Федеральные органы исполнительной власти Российской Федерации придают огромное значение разработке и выполнению мероприятий по обеспечению биологической безопасности нашей страны. Постановлением правительства Российской Федерации № 791 от 27 октября 2008 г. утверждена и выполняется Федеральная целевая программа «Национальная система химической и биологической безопасности Российской Федерации (2009-2013 гг.)», одной из основных целей которой является последовательное снижение до приемлемого уровня риска воздействия опасных биологических факторов на биосферу, техносферу и экологическую систему, а особое внимание должно быть уделено потенциально опасным биологическим объектам, т.е. организациям, в которых проводятся работы с опасными биологическими материалами и агентами.

Актуальность поставленной цели объясняется тем, что на территории Российской Федерации свыше 160 организаций осуществляют деятельность, связанную с возбудителями инфекционных заболеваний 1-й и 2-й групп патогенности [2]. Федеральной службой по надзору в сфере защиты прав потребителей и благополучия человека зарегистрировано более 9000 организаций, имеющих лицензию на деятельность, связанную с использованием возбудителей инфекционных

(С Доброхотский О.Н., Дятлов А.И., 2013

Доброхотский Олег Нарьевич - кандидат медицинских наук, главный врач противочумной станции (е-таil: oleg_dobr@mail.ru, тел.: 8-4967-36-00-81).

Дятлов Иван Алексеевич - член-корреспондент РАМН, доктор медицинских наук, профессор, директор (е-mail: dyatlov@obolensk.org, тел.: 8-4967-36-00-03). 
заболеваний и выполнением работ с микроорганизмами 3-4-й групп патогенности [5].

Сегодня актуальными являются вопросы гармонизации санитарного законодательства в контексте создания и функционирования Таможенного союза и вступления Российской Федерации во Всемирную торговую организацию (ВТО) и Организацию экономического сотрудничества и развития (ОЭСР). Одним из принципиальных условий для подобной гармонизации является обеспечение биологической безопасности при работе с патогенными биологическими агентами (ПБА) на основе международных стандартов.

В настоящее время мировое научное сообщество выработало единый подход к обеспечению биологической безопасности при работе с ПБА, основанный на концепции управления биорисками, что нашло отражение в международных [7, 9, 11, 13] и национальных $[8,12]$ руководящих документах.

Федеральной службой по надзору в сфере защиты прав потребителей и благополучия человека проведена значительная работа по разработке и внедрению нормативных и методических документов по оценке риска для здоровья населения при воздействии химических веществ.

Элементы методологии анализа риска при воздействии химических веществ включают в себя оценку риска, управление риском и информирование о риске, а для оценки риска используются следующие показатели: референтные дозы и концентрации для условий острых, подострых и хронических воздействий, региональные уровни минимального риска, факторы канцерогенного потенциала, гигиенические нормативы, установленные по прямым эффектам на здоровье человека, параметры зависимости «доза/концентрация-ответ» [14].

Однако база методических документов по оценке и управлению биорисками пока не получила должного развития по причине основной методической сложности, состоящей в том, что количественные показатели, характеризующие ПБА, не информативны, так как не работает зависимость «доза/концентрация-ответ». При увеличении концентрации микроорганизмов свыше зара- зительной дозы тяжесть инфекционного заболевания не изменяется, а некоторые инфекционные болезни могут быть вызваны единичными клетками возбудителей заболевания [15].

С целью учета особенностей при работе с ПБА и для минимизации биорисков в работе представлено направление по разработке методического подхода по управлению биорисками.

Пользуясь терминологией российского стандарта [1], где риск - сочетание (произведение) вероятности (или частоты) нанесения ущерба и тяжести этого ущерба, перевод на русский язык определения «биориск» [7] выглядит следующим образом: биологический риск - это вероятность или возможность наступления неблагоприятного события (инфицирование при контакте с ПБА), которое может привести к причинению ущерба (внутрилабораторное заражение). Проведение работ с ПБА может способствовать возникновению следующих основных видов ущерба: внутрилабораторное заражение персонала, выход ПБА в окружающую среду с последующим заражением животных и людей, несанкционированный вынос ПБА с целью биотерроризма, загрязнение окружающей среды газообразными, твердыми и жидкими отходами.

Учитывая, что случаи внутрилабораторных инфекционных заболеваний отмечаются на протяжении более чем векового периода изучения патогенных микроорганизмов и во много раз по количеству превышают другие виды ущерба $[4,6,10]$, в дальнейшем вопросы управления биорисками при работе с ПБА будем рассматривать на примере только одного вида ущерба- внутрилабораторного заражения персонала.

Используя основные положения методологии управления рисками, можно выделить четыре этапа обеспечения биобезопасности при работе с ПБА:

1) планирование и организация мероприятий;

2) идентификация опасностей;

3) оценка биорисков;

4) управление биорисками.

На этапе планирования и организации мероприятий проводятся определение цели 
и задачи планируемой работы, выявление источников информации, подбор группы исполнителей, определение финансовых и материальных ресурсов, подготовка управленческих решений.

Следует учесть, что стадия проектирования объекта, предназначенного для работы с ПБА, имеет ключевое значение для обеспечения биобезопасности, так как на этой стадии определяются: назначение объекта и соответствующий уровень биобезопасности, размещение объекта на местности, определение величины санитарно-защитной зоны, объемно-планировочные решения, проектирование инженерных систем, подбор оборудования и приборов. Такой подход, когда на стадии проектирования проводят выявление опасностей, оценку биорисков и разработку проектных решений по управлению ими с учетом вида планируемых работ, свойств используемых ПБА, критериев надежности и эффективности инженерных систем, позволит определить минимально достаточный уровень инженерного оснащения специальной техникой безопасности, функциональной эффективности инженерных систем и обеспечить биологическую безопасность объекта.

На этапе идентификации опасностей определяются возможные опасности при работе с ПБА и дается описание их источников. В соответствии со стандартом [1] опасность - это потенциальный источник ущерба. В контексте рассматриваемого вопроса идентификации подлежат опасности, приводящие к внутрилабораторному заражению персонала.

Источниками информации для выявления опасностей являются:

- нормативные документы, локальные нормативные акты, инструкции к приборам и др.;

- результаты государственного санитарно-эпидемиологического надзора; троля;

- результаты производственного кон-

- результаты аттестации рабочих мест; ников;

- результаты аудита (опроса) сотруд-

- опыт практической деятельности.

Выявленные опасности должны быть документально оформлены. Примерный ре- естр может содержать следующие идентифицированные опасности, приводящие к внутрилабораторному заражению:

- зараженные животные (укусы, оцарапывание, ослюнение);

- аэрозолирование ПБА (центрифугирование, высушивание, пипетирование, зараженные животные, бой стеклянной лабораторной посуды);

- физические объекты с высокой потенциальной энергией (ротор центрифуги);

- предметы с недостаточной механической прочностью (стеклянная лабораторная посуда) или опасной формы (иголки, скальпели);

- высокотемпературные потоки и емкости под давлением;

- электрические цепи с опасным напряжением;

- нарушение нормативных требований к рабочему месту (освещенность, микроклимат);

- психоэмоциональные перегрузки при работе с ПБА;

- недостаточные образование, профессиональная подготовка, квалификация, стаж, опыт;

- недостаточный уровень внимания, самодисциплины; неадекватность поведения;

- нарушение нормативных требований биологической безопасности;

- несоответствующее состояние здоровья (телесное, духовное, социальное), а также возраст, пол работника, образ жизни;

- наличие вредных привычек (алкоголизм, наркомания);

- нарушения работы систем вентиляции, воздухоснабжения, неисправность средств индивидуальной защиты.

Идентификация опасностей завершается выбором направления деятельности прекращение анализа опасности ввиду его незначительности или более детальная оценка риска реализации опасности в виде инфекционного заболевания. Необходимо отметить, что невыявленные опасности не подвергаются дальнейшему рассмотрению и исчезают из поля зрения при управлении биорисками.

При сравнительной оценке биорисков возникает необходимость знать их количе- 
ственные значения, что особенно востребовано при определении первоочередности принятия управленческих решений на этапе управления биорисками, особенно при ограниченности финансовых ресурсов.

Количественная оценка биорисков может быть проведена по формуле [1]

$$
R=\sum_{i=1}^{N} U_{i} P_{i},
$$

где $R$ - величина биориска; $U_{i}-$ ущерб (внутрилабораторное инфекционное заболевание); $P_{i}-$ вероятности наступления ущерба; $N$ - количество дискретных значений возможных ущербов.

В качестве количественных показателей ущерба можно использовать:

- количество и тяжесть инфекционных заболеваний;

- продолжительность временной утраты трудоспособности;

- сумму пособий по временной нетрудоспособности;

- количество случаев стойкой утраты профессиональной трудоспособности;

- степень утраты профессиональной трудоспособности, \%;

- сумму расходов на обеспечение по страхованию.

Для определения вероятности наступления ущерба можно использовать:

- статистические данные;

- метод логического анализа дерева событий;

- экспертную оценку специалистов.

На основании документированной оценки биорисков в организации следует разработать и внедрить рекомендации по управлению биорисками с целью снижения до допустимых приемлемых уровней риска возникновения внутрилабораторных инфекций, что является следующим, но не заключительным этапом обеспечения биобезопасности, так как после контроля за внедренными мероприятиями применяются корректирующие меры с целью непрерывного (процессного) управления биорисками.
Европейским комитетом по стандартизации (CEN) разработан и введен в действие стандарт по управлению лабораторными биорисками, являющийся своего рода планом внедрения в лаборатории системы управления биорисками. На его основе будет организована международная система аккредитации по управлению биорисками при работе с ПБА (Biorisk Management), создание которой запланировано Всемирной организацией здравоохранения.

В большинстве развитых стран действенным финансовым механизмом, регулирующим проблемы обеспечения безопасной эксплуатации предприятий (в том числе при работе с ПБА) и возмещения ущерба, является страхование.

Государственная доктрина Российской Федерации предусматривает комплекс мер государственной поддержки в области обеспечения биологической безопасности по совершенствованию системы страхования рисков.

С 1 января 2012 г. вступил в силу Федеральный закон об обязательном страховании гражданской ответственности владельца опасного объекта за причинение вреда в результате аварии. К сожалению, в перечень опасных объектов, владельцы которых обязаны осуществлять обязательное страхование, не внесены организации, предназначенные для работы с ПБА.

Таким образом, разработка и внедрение методологии управления биорисками при работе с ПБА будет являться инновационной, повышающей эффективность действующей системы биобезопасности, позволит получать достаточно ясные результаты, пригодные для принятия адекватных управленческих решений по обеспечению биобезопасности.

Необходимым условием для реализации концепции управления биорисками при работе с ПБА является разработка (адаптация) методик по оценке биорисков и разработка российского стандарта по управлению биорисками при работе с ПБА на основе международного стандарта CWA 15793: 2008. 


\section{Список литературы}

1. ГОСТ Р 12.0.010-2009. Определение опасностей и оценка рисков [Электронный ресурс]. - URL: http: //www.vsegost.com/Catalog/49/49985.shtml (дата обращения: 08.07.2012).

2. Национальная система химической и биологической безопасности Российской Федерации (2009-2013 гг.): Федеральная целевая программа [Электронный ресурс]. - URL: http: // www.mchs.gov.ru/activities/? ID = 125441 (дата обращения: 16.11.2009).

3. О мерах по реализации полномочий Единой государственной Федеральной централизованной системы государственного санитарно-эпидемиологического надзора в области обеспечения биологической и химической безопасности: постановление главного государственного санитарного врача Российской Федерации № 50 от 04.08.09 г. [Электронный ресурc]. - URL: http: //www.bestpravo.ru/federalnoje/hj-pravila/ r7g.htm (дата обращения: 01.07.2012).

4. О внутрилабораторном заражении брюшным тифом: письмо Минздрава РФ № 1100/1089-04-113 от 22.04.2004 г. [Электронный ресурс]. - URL: http: // www.law7.ru/base12/part9/d12ru9003.htm (дата обращения: 19.08.2012).

5. Реестр выданных лицензий на деятельность, связанную с использованием возбудителей инфекционных заболеваний, и лицензий на деятельность в области использования источников ионизирующего излучения (генерирующих) (выданные Федеральной службой, включая Управления) [Электронный ресурс] / Федеральная служба по надзору в сфере защиты прав потребителей и благополучия человека. - URL: http: // fp.crc.ru/ licenfr/? type = list (дата обращения: 11.09.2012).

6. Ставский Е.А. Совершенствование системы обеспечения безопасности работ с вирусами I-II групп патогенности: автореф. дис. ... д-ра мед. наук. - Кольцово, 2008. - С. 42-42.

7. Biorisk management: Laboratory biosecurity guidance [Электронный pecypc] / World Health Organization. September, 2006. - URL: http: //www.who.int/csr/resources/publications/biosafety/WHO_CDS_EPR_2006_6.pdf (дата обращения: 10.08.2012).

8. Biosafety in microbiological and biomedical laboratories. 5th ed. [Электронный ресурс] / U.S. Department of Health and Human Services; Public Health Service; Centers for Disease Control and Prevention; National Institutes of Health. - 2009. - URL: http: //www.cdc.gov/biosafety/publications/bmbl5/BMBL5_introduction.pdf (дата обращения: 20.07.2012).

9. CWA 15793: 2008. Laboratory biorisk management standard / G. Burns, A.Z. Pharmaceuticals, P. Seechurn // Northern BSOs Meeting (Glasgow, 15 ${ }^{\text {th }}$ May 2009). - Glasgow, 2009. - 25 p.

10. Fleming D.O., Hunt D.L. Биологическая безопасность: принципы и практика. - 3-е изд. - Вашингтон: ASM Press, 2000. - P. 35-54.

11. Laboratory biosafety manual / World Health Organization // WHO Library Cataloguing-in-Publication Data World Health Organization. - 3rd ed. - Geneva: Laboratory biosafety manual, 2004.

12. Laboratory Biosafety Guidelines. 3rd ed. [Электронный pecypc]. - Canada, 2004. - URL: http: // www.phac-aspc.gc.ca/publicat/lbg-ldmbl-04/ (дата обращения: 05.01.2005).

13. Strategic Framework for Action 2012-2016 / Laboratory Biorisk Management, WHO. - HSE, 2012. - 18 p.

14. Р 2.1.10.1920-04. Руководство по оценке риска для здоровья населения при воздействии химических веществ, загрязняющих окружающую среду [Электронный ресурс]. - URL: http: // tehnorma.ru/ normativbase/46/46715/index.htm (дата обращения: 15.10.2010).

15. Дроздов О.Г., Горин Н.С., Джиндоян Л.С., Тарасенко В.М. Основы техники безопасности в микробиологических и вирусологических лабораториях. - М.: Медицина, 1987. - 256 с.

\section{References}

1. GOST R 12.0.010-2009. Opredelenie opasnostey i otsenka riskov [Hazard identification and risk assessment]. Available at: http: //www.vsegost.com/Catalog/49/49985.shtml.

2. Natsional'naya sistema khimicheskoy i biologicheskoy bezopasnosti Rossiyskoy Federatsii (2009-2013 gg.): Federal'naya tselevaya programma [The national system of chemical and biological safety of the Russian Federation (2009-2013): A federal target program]. Available at: http: // www.mchs.gov.ru/activities/? ID = 125441 .

3. O merakh po realizatsii polnomochiy Edinoy gosudarstvennoy Federal'noy tsentralizovannoy sistemy gosudarstvennogo sanitarno-epidemiologicheskogo nadzora v oblasti obespecheniya biologicheskoy i khimicheskoy bezopasnosti: Postanovlenie Glavnogo gosudarstvennogo sanitarnogo vracha Rossiyskoy Federatsii № 50 ot 04.08.09 g. [On measures to implement the powers of the Unified State Federal Centralized System of State Health and Epidemiological Surveillance in the Field of Biological and Chemical safety: The Regulation no. 50 of the Chief State Medical Officer of the Russian Federation as of 04.08.09]. Available at: http: http: //www.bestpravo.ru/federalnoje/hj-pravila/r7g.htm.

4. O vnutrilaboratornom zarazhenii bryushnym tifom: Pis'mo Minzdrava RF № 1100/1089-04-113 ot 22.04.2004 g. [Intra-laboratory typhoid fever infection]. Available at: http: // www.law7.ru/base12/part9/d12ru9003.htm.

5. Reestr vydannykh litsenziy na deyatel'nost', svyazannuyu s ispol'zovaniem vozbuditeley infektsionnykh zabolevaniy, i litsenziy na deyatel'nost' v oblasti ispol'zovaniya istochnikov ioniziruyushchego izlucheniya (generiru- 
yushchikh) (vydannye Federal'noy sluzhboy, vklyuchaya Upravleniya) [The registry of licenses for activities involving the use of infectious agents, and licenses for the activities involving the use of sources generating ionizing radiation (issued by the Federal Service, including its Departments)]. Available at: http: //fp.crc.ru/ licenfr/? type = list.

6. Stavskiy E.A. Sovershenstvovanie sistemy obespecheniya bezopasnosti rabot s virusami I-II grupp patogennosti: avtoref. dis. ... d-ra med. nauk [The improvement of the system ensuring security when working with viruses belonging to I-II pathogenicity groups: summary of the thesis ... of Dr. of Med. Sciences]. Kol'tsovo, 2008. 42 p.

7. Biorisk management: Laboratory biosecurity guidance. World Health Organization. September, 2006. Available at: http: //www.who.int/csr/resources/publications/biosafety/WHO_CDS_EPR_2006_6.pdf.

8. Biosafety in microbiological and biomedical laboratories. 5th ed. U.S. Department of Health and Human Services; Public Health Service; Centers for Disease Control and Prevention; National Institutes of Health, 2009. Available at: http: //www.cdc.gov/biosafety/publications/bmbl5/ BMBL5_introduction.pdf.

9. CWA 15793: 2008. Laboratory biorisk management standard. G. Burns, A.Z. Pharmaceuticals, P. Seechurn. Northern BSOs Meeting (Glasgow, 15th May 2009). Glasgow, 2009. 25 p.

10. Fleming D.O., Hunt D.L. Biologicheskaya bezopasnost': printsipy i praktika [Biological safety: principles and practice]. 3 ed. Vashington: ASM Press, 2000, pp. 35-54.

11. Laboratory biosafety manual. 3 ed. World Health Organization. WHO Library Cataloguing-in-Publication Data World Health Organization. Geneva: Laboratory biosafety manual, 2004.

12. Laboratory Biosafety Guidelines. 3rd ed. Canada, 2004. Available at: http: //www.phac-aspc.gc.ca/publicat/lbgldmbl-04/.

13. Strategic framework for action 2012-2016. HSE: Laboratory Biorisk Management, WHO, 2012.18 p.

14. P 2.1.10.1920-04. Rukovodstvo po otsenke riska dlya zdorov'ya naseleniya pri vozdeystvii khimicheskikh veshchestv, zagryaznyayushchikh okruzhayushchuyu sredu [Guidelines for human health risk assessment of exposure to chemicals polluting the environment]. Available at: http: // tehnorma.ru/normativbase/46/46715/index.htm.

15. Drozdov O.G., Gorin N.S., Dzhindoyan L.S., Tarasenko V.M., Osnovy tekhniki bezopasnosti v mikrobiologicheskikh i virusologicheskikh laboratoriyakh [The fundamentals of occupational safety in microbiological and virological laboratories]. Moscow: Meditsina, 1987. 256 p.

\title{
THE CHARACTERISTICS OF HEALTH RISK ANALYSIS WHEN WORKING WITH PATHOGENIC BIOLOGICAL AGENTS
}

\section{O.N. Dobrokhotskiy', A.I. Dyatlov²}

\author{
1 Hospital no. 164 of the Federal Biomedical Agency, Russian Federation, urban settlement Obolensk, \\ Serpukhov district, the Moscow Region, 142279, \\ 2 State Research Center for Applied Microbiology and Biotechnology of the the Federal Service on \\ Customers' Rights Protection and Human Well-Being Surveillance, Russian Federation, urban settlement \\ Obolensk, Serpukhov district, Moscow region, 142279
}

Issues of biological safety are of particular relevance and are a priority in ensuring the national security of the Russian Federation. In this work, we outline the ways of developing a methodical approach to bio-risk management when working with pathogenic biological agents (PBA) in order to minimize the risk of intra-laboratory infection. We show that the development and implementation of the methodology for bio-risk management when working with PBA will be the basis for developing and making management decisions which increase the effectiveness of the current biological safety system.

Keywords: bio-risk assessment and management, pathogenic biological agents, intra-laboratory staff infection.

(C) Dobrokhotskiy O.N., Dyatlov A.I., 2013

Dobrohotskiy Oleg Nar'evich - PhD, head doctor of Plague Control Station (e-mail: oleg_dobr@mail.ru, tel.: 8 (4967) 36-00-81).

Dyatlov Ivan Alekseevich - corresponding member of RAMS, D. Sc., professor, director (e-mail: dyatlov@ obolensk.org, tel.: 8 (4967) 36-00-03). 
УДК 349.6;614.7

\title{
ЗАКОНОДАТЕЛЬНОЕ ОБЕСПЕЧЕНИЕ ОЦЕНКИ РИСКА ВОЗДЕЙСТВИЯ НА ЗДОРОВЬЕ НАСЕЛЕНИЯ КАЧЕСТВА АТМОСФЕРНОГО ВОЗДУХА В РЕСПУБЛИКЕ БЕЛАРУСЬ
}

\author{
Т.Е. Науменко1, В.А. Рыбак², Т.Д. Гриценко1, \\ Л.М. Шевчук ${ }^{1}$, А.Е. Пшегрода ${ }^{1}$, А.Н. Ганькин ${ }^{1}$ \\ 1 Республиканский научно-практический центр гигиены, Республика Беларусь, \\ 220012, Минск, ул. Академическая, 8, \\ 2 Центральный научно-исследовательский институт комплексного использования водных ресурсов, \\ Республика Беларусь, 220086, г. Минск, ул. Славинского, 1, корп. 2
}

Проведена гармонизация санитарных норм, правил и гигиенических нормативов в соответствии с международными регламентами, руководствами и обязательствами Республики Беларусь по международным конвенциям. В Республике Беларусь законодательно действуют 653 предельно допустимые концентрации, дифференцированные по времени - максимально разовая, среднесуточная, среднегодовая, и 1424 ориентировочно безопасных уровня воздействия, среди которых с утвержденным классом опасности - 17 загрязняющих веществ. Разработан расчетно-программный комплекс по оценке риска воздействия на здоровье населения качества атмосферного воздуха при установлении оптимальной достаточности размеров санитарно-защитных зон, реализующий положения Инструкции по применению «Методика оценки риска здоровью населения факторов среды обитания», утвержденной заместителем министра здравоохранения Республики Беларусь 08.06.2012 г., регистрационный № 025-1211.

Ключевые слова: атмосферный воздух, загрязняющие вещества, расчетно-программный комплекс, оценка риска.

Одним из основных принципов охраны здоровья граждан Республики Беларусь в целях устойчивого развития является приоритет профилактики - разработка и первоочередная реализация мероприятий, направленных на предупреждение, снижение риска развития заболеваний, раннее выявление причин и условий их возникно- вения с учетом воздействия факторов среды обитания. Согласно закону Республики Беларусь «О санитарно-эпидемиологическом благополучии населения» № 340-3 от 7.01.2012 г. государственная санитарно-гигиеническая экспертиза проводится в целях:

- комплексной оценки воздействия факторов среды обитания человека на санитар-

( Науменко Т.Е., Рыбак В.А., Гриценко Т.Д., Шевчук Л.М., Пшегрода А.Е., Ганькин А.Н., 2013

Науменко Татьяна Емельяновна - кандидат медицинских наук, доцент, заведующий лабораторией комплексной оценки риска воздействия факторов среды (e-mail: NaumenkoTE@ tut.by, тел.: 375-17-284-13-79).

Рыбак Виктор Александрович - кандидат технических наук, доцент, директор (e-mail: 6774338@ tut.by, тел.: 8-029-677-43-38).

Гриценко Татьяна Дмитриевна - кандидат биологических наук, ведущий научный сотрудник лаборатории комплексной оценки риска воздействия факторов среды (e-mail: gritsenkotd@ rambler.ru, тел.: 375-17-284-13-79).

Шевчук Лариса Михайловна - кандидат медицинских наук, заместитель директора по научной работе (e-mail: sheuchuklm@mail.ru, тел.: 375-17-284-13-70).

Пшегрода Александр Евгеньевич - научный сотрудник лаборатории комплексной оценки риска воздействия факторов среды (e-mail: rspch@ rspch.by, тел.: 375-17-284-13-79).

Ганькин Александр Николаевич - аспирант, младший научный сотрудник лаборатории комплексной оценки риска воздействия факторов среды (e-mail: gankinan@gmail.com, тел.: 375-17-284-13-79). 
но-эпидемиологическую обстановку, жизнь и здоровье населения;

- предотвращения неблагоприятного воздействия объектов, подлежащих государственной санитарно-гигиенической экспертизе, на жизнь и здоровье населения.

Объектами, подлежащими государственной санитарно-гигиенической экспертизе, являются проекты санитарно-защитных зон (С33) организаций, сооружений и иных объектов, оказывающих воздействие на здоровье человека и окружающую среду и определяемых Министерством здравоохранения Республики Беларусь (Статья 16. Государственная санитарно-гигиеническая экспертиза). Статья 41 декларирует права главных государственных санитарных врачей «поручать проведение экспертиз и консультаций по оценке влияния факторов среды обитания человека на его здоровье органам и учреждениям, входящим в систему Министерства здравоохранения Республики Беларусь».

Оценка риска - система процедур, регламентированных руководящими документами Министерства здравоохранения Республики Беларусь для определения вероятности появления неблагоприятных изменений здоровья, связанных с воздействием факторов среды обитания.

Интенсификация промышленного, агропромышленного и гражданского строительства с учетом рационального землепользования приводит к возрастанию роли оценки риска влияния на здоровье населения шума и загрязняющих веществ в атмосферном воздухе, обусловленных выбросами и эмиссиями объектов. Принцип экологической модели населенного пункта для создания благоприятных условий проживания людей способствует рациональному функциональному зонированию урбанизированных территорий, важным элементом которого являются санитарно-защитные зоны. Согласно санитарным нормам, правилам и гигиеническим нормативам «Гигиенические требования к организации санитарно-защитных зон предприятий, соору- жений и иных объектов, являющихся объектами воздействия на здоровье человека и окружающую среду», утвержденным постановлением Министерства здравоохранения Республики Беларусь 10.02.2011 г. № 11 (п. 10), установление размеров расчетной С33 проектируемых объектов проводится при наличии проектов С33 с расчетами рассеивания выбросов загрязняющих веществ в атмосферном воздухе, уровней физического воздействия, с оценкой риска здоровью населения от воздействия загрязняющих веществ в атмосферном воздухе, обусловленных выбросами объекта. Система раннего предупреждения неблагоприятного воздействия экологических факторов на здоровье человека диктует необходимость развития наиболее оперативных приемов оценки риска, позволяющих в кратчайшие сроки и с минимальными затратами предоставить достоверные данные по оценке риска для принятия адекватного управленческого решения [1]. Такое положение диктует необходимость разработки ускоренной процедуры оценки риска влияния на здоровье населения качества атмосферного воздуха на основе современных информационных технологий. Разработан расчетно-программный комплекс по оценке риска воздействия на здоровье населения качества атмосферного воздуха при установлении оптимальной достаточности размеров санитарнозащитной зоны, реализующий положения Инструкции по применению «Методика оценки риска здоровью населения факторов среды обитания», утвержденной заместителем министра здравоохранения Республики Беларусь 08.06.2012 г., регистрационный № 025-1211.

Вышеуказанная Инструкция по применению выполнена в рамках задания 06.01. «Разработать и внедрить методологию комплексной оценки риска воздействия загрязнений атмосферного воздуха на здоровье населения для обеспечения ведения предсаннадзора» отраслевой научно-технической программы «Здоровье и окружающая среда». Гигиеническая оценка 
Градации популяционного здоровья и уровней риска в зависимости от степени загрязнения атмосферного воздуха

\begin{tabular}{|c|c|c|c|}
\hline $\begin{array}{c}\text { Степень загрязнения } \\
\text { атмосферного } \\
\text { воздуха } \\
\end{array}$ & Уровень риска & $\begin{array}{c}\text { Градация } \\
\text { популяционного здоровья }\end{array}$ & Приоритетность действий \\
\hline $\begin{array}{c}\text { Опасная } \\
\text { V }\end{array}$ & $\begin{array}{c}1: 1000 \\
10-3(\mathrm{E}-03)^{*} \\
\text { Риск оценивается } \\
\text { как недопустимый }\end{array}$ & $\begin{array}{c}\text { Срыв адаптации (превы- } \\
\text { шение фонового уровня } \\
\text { заболеваемости в не-- } \\
\text { сколько раз) }\end{array}$ & $\begin{array}{l}\text { Высокая приоритетность. } \\
\text { Срочное принятие комплекса экс- } \\
\text { тренных мер по снижению риска }\end{array}$ \\
\hline $\begin{array}{l}\text { Сильная } \\
\text { IV }\end{array}$ & $\begin{array}{c}1: 10000 \\
10-4(\mathrm{E}-04)^{*} \\
\text { Риск оценивается } \\
\text { как неприемлемый }\end{array}$ & $\begin{array}{c}\text { Перенапряжение } \\
\text { адаптации } \\
\text { (достоверное превышение } \\
\text { фонового и высшей гра- } \\
\text { ницы фонового уровня } \\
\text { заболеваемости) } \\
\end{array}$ & $\begin{array}{l}\text { Высокая приоритетность. } \\
\text { Идентификация опасности, прове- } \\
\text { дение исследований по оценке рис- } \\
\text { ка для здоровья и одновременное } \\
\text { осуществление экстренных мер по } \\
\text { снижению риска }\end{array}$ \\
\hline $\begin{array}{l}\text { Умеренная } \\
\text { III }\end{array}$ & \begin{tabular}{c|}
$1: 100000$ \\
$10-5($ Е-05)* \\
Риск считается \\
достаточно высоким \\
\end{tabular} & $\begin{array}{c}\text { Напряжение адаптации } \\
\text { (достоверное превышение } \\
\text { фонового уровня } \\
\text { заболеваемости) } \\
\end{array}$ & $\begin{array}{l}\text { Средняя приоритетность. } \\
\text { Идентификация опасности и при- } \\
\text { нятие решений о снижении уров- } \\
\text { ней риска } \\
\end{array}$ \\
\hline $\begin{array}{l}\text { Слабая } \\
\text { II }\end{array}$ & \begin{tabular}{c|}
$1: 1000000$ \\
$10-6(\mathrm{E}-06)^{*}$ \\
Приемлемый \\
уровень риска \\
\end{tabular} & \begin{tabular}{c|} 
Компенсация/ \\
резистентность \\
(фоновый уровень \\
заболеваемости) \\
\end{tabular} & $\begin{array}{l}\text { Низкая приоритетность. } \\
\text { Действующая система управления } \\
\text { риском. } \\
\text { Дополнительных мер не требуется }\end{array}$ \\
\hline $\begin{array}{l}\text { Допустимая } \\
\text { I }\end{array}$ & $\begin{array}{c}1: 10000000 \\
10-7(\mathrm{E}-07)^{*} \\
\text { Приемлемый } \\
\text { уровень риска }\end{array}$ & $\begin{array}{c}\text { Адаптация } \\
\text { (фоновый уровень } \\
\text { заболеваемости) }\end{array}$ & $\begin{array}{l}\text { Низкая приоритетность. } \\
\text { Действующая система управления } \\
\text { риском. } \\
\text { Дополнительных мер не требуется }\end{array}$ \\
\hline
\end{tabular}

степени загрязнения атмосферного воздуха проводится по среднесуточным и максимально разовым концентрациям с расчетом комплексного показателя загрязнения и установлением уровней риска согласно градациям популяционного здоровья (таблица) [1].

Интегрированная информационно-аналитическая система по оценке риска содержит электронную базу данных о риске для здоровья населения под влиянием приоритетных химических веществ. Ядром системы является собрание файлов, в которых представлены токсиколого-гигиеническая характеристика приоритетных загрязняющих химических веществ и их гигиенические нормативы - предельно допустимые концентрации (ПДК), класс опасности, преимущественный характер действия на органы и системы. Сопроводительная документация включает: алфавитный список химических файлов согласно нумерации CAS (Chemical Abstracts
Service); описание положений и методов; руководство пользователя с подробным описанием процедур и демонстрационный пример; глоссарий терминов, определений, акронимов по методологии оценки риска $[2,3]$.

Автоматизированы расчеты и оценка риска неканцерогенного воздействия на здоровье населения (потенциальный риск рефлекторного, хронического действия, индексы и коэффициенты опасности); канцерогенных эффектов; риска влияния приоритетных загрязнителей на критические органы и системы (нервная система, органы дыхания, сердечно-сосудистая система, кроветворная система, процессы развития организма). Расчетно-программный комплекс «Компьютерная информационнорасчетная система по оценке риска воздействия качества атмосферного воздуха на здоровье населения» зарегистрирован в Отраслевом фонде алгоритмов и программ 
Республиканского центра медицинских технологий, информатизации, управления и экономики здравоохранения (инв. № 000238, дата регистрации 06.12.2012 г.).

Методология оценки риска здоровью человека от влияния экологических факторов востребована особенно при конфликтных градостроительных ситуациях, при необходимости корректировки размеров санитарно-защитных зон.

На саммите $\mathrm{OOH}$ «Планета Земля» (Риоде-Жанейро, 1992 г.) была принята новая модель устойчивого развития - энергичный экономический рост в сочетании с экологической необходимостью сохранения наиболее ценных ресурсов нашей планеты - земли, воздуха и воды. На конференции ООН в Рио-де-Жанейро, 2012 г. (Рио + 20), принята концепция «зеленой» экономики в контексте устойчивого развития с мобилизацией программ преобразований, носящих трансформационный характер [4].

В последнее время в мировой общественно-политической и научной сфере активно продвигается концепция «зеленой» (или «экологичной») экономики. «Зеленая» экономика повышает благосостояние людей и обеспечивает социальную справедливость, при этом существенно снижает риски для окружающей среды и ее обеднения.

Проведена гармонизация санитарных норм, правил и гигиенических нормативов в соответствии с международными регламентами, руководствами и обязательствами Республики Беларусь по международным конвенциям:

- санитарные нормы, правила и гигиенические нормативы «Гигиенические требования к обеспечению качества атмосферного воздуха населенных пунктов и мест отдыха населения», утвержденные постановлением Министерства здравоохранения Республики Беларусь от 30.06.2009 г. № 77;

- санитарные нормы, правила и гигиенические нормативы «Гигиенические требования к проектированию, строительству, реконструкции и вводу объектов в эксплуатацию», утвержденные постановлением
Министерства здравоохранения Республики Беларусь 10.01.2011 г. № 12;

- «Нормативы предельно допустимых концентраций загрязняющих веществ в атмосферном воздухе и ориентировочно безопасных уровней воздействия загрязняющих веществ в атмосферном воздухе населенных пунктов и мест массового отдыха населения», утвержденные постановлением Министерства здравоохранения Республики Беларусь 30.12.2010 г. № 186;

- «Классы опасности загрязняющих веществ в атмосферном воздухе и установление порядка отнесения загрязняющих веществ к определенным классам опасности загрязняющих веществ», утвержденные постановлением Министерства здравоохранения Республики Беларусь 21.12.2010 г. № 174. В Республике Беларусь законодательно действуют 653 предельно допустимые концентрации, дифференцированные по времени - максимально разовая, среднесуточная, среднегодовая, и 1424 ориентировочно безопасных уровня воздействия, среди которых с утвержденным классом опасности - 17 загрязняющих веществ.

ГУ «Республиканский научно-практический центр гигиены» проведено около 250 исследований по оценке риска воздействия на здоровье населения шума и загрязняющих веществ в атмосферном воздухе, обусловленных выбросами и эмиссиями объектов различного профиля, при обосновании расчетных размеров санитарно-защитной зоны и при оценке воздействия на окружающую среду планируемого вида деятельности. Выборочно проведен анализ результатов исследований по оценке риска 78 объектов различного вида экономической деятельности на всей территории Республики Беларусь. Приоритетными веществами по факту наличия их в выбросах объектов определены: азота диоксид, углерода оксид, твердые частицы (недифференцированная по составу пыль/аэрозоль) $100 \%$, серы диоксид - $74 \%$, фенол - $45 \%$, формальдегид - $44 \%$, углеводороды пре- 
дельные алифатического ряда $\mathrm{C}_{11}-\mathrm{C}_{19}-$ $36 \%$, аммиак - $36 \%$, бензол - $23 \%$, сероводород - $23 \%$, толуол, этилбензол, марганец и его соединения - $20 \%$.

Настоятельной необходимостью представляется разработка четких положений и требований, регламентирующих организа- цию натурных аналитических (лабораторных) исследований содержания загрязняющих веществ в атмосферном воздухе на границе С33 и в жилой зоне. Экологическая безопасность и устойчивое развитие территорий возможны лишь при наличии действенного контроля за состоянием окружающей среды.

\section{Список литературы}

1. Филонов В.П., Соколов С.М., Науменко Т.Е. Эколого-эпидемиологическая оценка риска для здоровья человека качества атмосферы: монография. - Минск, 2001. - 187 с.

2. Гигиеническое обеспечение охраны здоровья населения при планируемом виде деятельности в Республике Беларусь / Т.Е. Науменко, С.М. Соколов, Л.М. Шевчук, В.П. Филонов // Материалы XI Всерос. съезда гигиенистов и санитарных врачей: сб. ст. - М., Ярославль: Канцлер, 2012. - Т. 1. - С. 597-600.

3. Расчетно-программный комплекс по оценке риска воздействия на здоровье населения качества атмосферного воздуха / Т.Е. Науменко, В.А. Рыбак, С.М. Соколов, Т.Д. Гриценко, Л.М. Шевчук, А.Е. Пшегрода, А.Н. Ганькин // Здоровье и окружающая среда: сб. науч. тр. / Респ. науч.-практ. центр гигиены; гл. ред. Л.П. Половинкин. Минск, 2012. - Вып. 21. - С. 142-151.

4. Будущее, которого мы хотим: итоговый документ конференции Организации объединенных наций по устойчивому развитию, Рио-де-Жанейро, Бразилия, 20-22 июня 2012 года [Электронный ресурс]. URL: http: //www.socionauki.ru/almanac/noo21v/files/buduwee_kotorogo_my_hotim_oon.pdf (дата обращения: 9.10.2012).

\section{References}

1. Filonov V.P., Sokolov S.M., Naumenko T.E. Ekologo-epidemiologicheskaya otsenka riska dlya zdorov'ya cheloveka kachestva atmosfery [An ecological and epidemiological health risk assessment of ambient air quality]. Minsk, 2001. 187 p.

2. Naumenko T.E., Sokolov S.M., Shevchuk L.M., Filonov V.P. Gigienicheskoe obespechenie okhrany zdorov'ya naseleniya pri planiruemom vide deyatel'nosti v Respublike Belarus' [Hygienic ensuring of human health protection at the planed activity type in the Republic of Belarus]. Itogi $i$ perspektivy obespecheniya sanitarnoepidemiologicheskogo blagopoluchiya naseleniya Rossiyskoy Federatsii: sbornik statey materialov XI Vserossiyskogo $s^{\prime \prime}$ ezda gigienistov $i$ sanitarnykh vrachey. Moscow, Yaroslavl: Kantsler, 2012, vol. 1, pp. 597-600.

3. Naumenko T.E., Rybak V.A., Sokolov S.M., Gritsenko T.D., Shevchuk L.M., Pshegroda A.E., Gan'kin A.N. Raschetno-programmnyy kompleks po otsenke riska vozdeystviya na zdorov'e naseleniya kachestva atmosfernogo vozdukha [A software for health risk assessment of ambient air quality]. Zdorov'e i okruzhayushchaya sreda: sbornik nauchnykh trudov. Ed. L.P. Polovinkin. Minsk: Respublikanskiy nauchno-prakticheskiy tsentr gigieny, 2012, vol. 21, pp. 142-151.

4. Budushchee, kotorogo my khotim: itogovyy dokument konferentsii Organizatsii ob"edinennykh natsiy po ustoychivomu razvitiyu [The outcome document of the United Nations Conference on Sustainable Development]. Rio de Janeiro, Braziliya, 20-22 june 2012. Available at: http: //www.socionauki.ru/almanac/noo21v/files/buduwee_kotorogo_my_hotim_oon.pdf. 


\section{THE LEGISLATIVE BASIS FOR ASSESSING THE RISK OF THE IMPACT OF AMBIENT AIR QUALITY ON HUMAN HEALTH IN THE REPUBLIC OF BELARUS}

\section{T.Ye. Naumenko1, V.A. Rybak², T.D. Gritsenko1, L.M. Shevchuk', A.Ye. Pshegroda1, A.N. Gankin ${ }^{1}$}

${ }_{1}^{1}$ Republican Science to Practice Center for Hygiene, the Republic of Belarus, 8 Academie st., Minsk, 220012, ${ }^{2}$ Central Research Institute of Complex Use of Water Resources, the Republic of Belarus, 1 Slavinskogo st., 2 unit, Minsk, 220086

We have harmonized health standards, rules and environmental health standards in accordance with international regulations, guidelines and liabilities of the Republic of Belarus upon international conventions. The legislation of the Republic of Belarus provides 653 MPCs differentiated according to a period of time - maximum concentration, maximum one-time concentration, average daily MPC, average yearly MPC, 1,424 tentative safe exposure levels (TSEL). Seventeen pollutants from the list of substances having TSELs have been confirmed to belong to a class of hazard. We have developed software for ambient air quality health risk assessment based on the determination of an optimum size of buffer zones implementing the provisions of the instructions "A method for assessing the health risk of environmental factors", approved by Deputy Minister of Public Health of the Republic of Belarus on 08 June 2012, registration no. 025-1211.

Keywords: ambient air, pollutants, software, risk assessment.

(C) Naumenko T.Ye., Rybak V.A., Gritsenko T.D., Shevchuk L.M., Pshegroda A.Ye., Gankin A.N., 2013

Naumenko Tayana Emelyanovna - Ph.D., docent, Head of Department of environmental impact of full risk assessment (e-mail: 6774338@tut.by, tel.: 8-029-67-743-38).

Rybak Viktor Alexandrovich - Ph.D., docent, Center Director (e-mail: 6774338@ tut.by, tel.: 8-029-67-743-38).

Gritsenko Tatyana Dmitrievna - PhD, leading research fellow of Department of environmental impact of full risk assessment (e-mail: gritsenkotd@ rambler.ru, tel.: 375-17-284-13-79).

Shevchuk Larisa Mihaylovna - PhD, Deputy Director for Research (e-mail: sheuchuklm@ mail.ru, tel.: 375-17-284-13-70).

Pshegoroda Alexandr Evgen'evich - Research fellow of Department of environmental impact of full risk assessment (e-mail: gritsenkotd@ rambler.ru, tel .: 375-17-284-13-79).

Gan'kin Alexandr Nikolaievich - postgraduate, junior research fellow of Department of environmental impact of full risk assessment (e-mail: gankinan@gmail.com, tel.: 375-17-284-13-79). 
УДК $340.132,614.3$

\title{
ОСНОВАНИЯ И ПРИНЦИПЫ ПРИМЕНЕНИЯ САНИТАРНЫХ И ФИТОСАНИТАРНЫХ МЕР В ПРАКТИКЕ ВСЕМИРНОЙ ТОРГОВОЙ ОРГАНИЗАЦИИ
}

\author{
М.С. Попов, А.Ю. Попова \\ Российская медицинская академия последипломного образования, \\ Россия, 123995, г. Москва, ул. Баррикадная, 2/1
}

Проведенный анализ норм Соглашения о применении санитарных и фитосанитарных мер и практики их применения Органом по разрешению споров Всемирной торговой организации (ВТО) и Апелляционным органом позволяет утверждать, что страна - член ВТО при наличии доказанной опасности какоголибо товара либо разумных оснований предполагать наличие опасности может запретить импорт такого товара. Требование проведения оценки риска и необходимость получения значимых научных доказательств являются ключевыми для поддержания баланса между интересами развития международной торговли и защитой жизни и здоровья человека. При условии, что импорт запрещен или существенно ограничен на недискриминационной основе, у страны-импортера нет оснований опасаться сколь-нибудь существенных последствий такого запрета. Более того, даже если такой запрет будет впоследствии признан необоснованным, у страны-импортера есть достаточный период для его отмены при отсутствии какихлибо санкций.

Ключевые слова: санитарные и фитосанитарные меры, оценка риска, уровни защиты.

В связи с вступлением во Всемирную торговую организацию (ВТО) Россия стала участницей ряда соглашений, в частности, Соглашения о применении санитарных и фитосанитарных мер (Agreement on the Application of Sanitary and Phytosanitary Measures) от 15.04.1994 г. (далее - Соглашение). Соответственно, при введении санитарных и фитосанитарных мер необходимо соблюдать правила и требования, установленные указанным Соглашением, а также сложившуюся практику применения Соглашения с учетом решений, принятых при рассмотрении Органом по разрешению споров ВТО и апелляционных жалоб стран-экспортеров на действия стран-импортеров по введению запретов или ограничений.

Анализ норм права ВТО и практики применения таких норм позволяет сформулировать следующие основные правила применения мер, связанных с запретом или ограничением доступа на внутренний рынок опасных либо потенциально опасных товаров.

Меры, принимаемые страной-импортером, должны быть основаны на международных стандартах, рекомендациях и руководствах (ст. 3.1 Соглашения).

При этом допускаются следующие варианты действий:

а) мера полностью соответствует международному стандарту и включает в себя все элементы такого стандарта (фактически международный стандарт имплементируется и становится частью национального законодательства);

б) мера основана на стандарте, т.е. включает некоторые, но не все элементы стандарта ${ }^{1}$.

1 Дело DS26 Европейский союз - гормоны (меры в отношении мяса и мясных продуктов, заявитель США).

(C) Попов М.С., Попова А.Ю., 2013

Попов Михаил Сергеевич - кандидат юридических наук (e-mail mail@nnk.ru, тел.: 8 (495) 641-58-72).

Попова Анна Юрьевна - доктор медицинских наук, профессор, заведующая кафедрой организации санитарноэпидемиологической службы (e-mail: rmapo@rmapo.ru, тел.: 8 (499) 458-95-63). 
Согласно ст. 3.3 Соглашения странаимпортер может установить для себя уровень защиты, отличающийся от уровня защиты, подразумеваемого международным стандартом, если имеется соответствующее научное обоснование или если такая страна определяет, что этот уровень санитарной или фитосанитарной защиты является надлежащим согласно соответствующим положениям пунктов 1-8 ст. 5 Соглашения. Приемлемый уровень защиты страны-импортера может быть выше, чем подразумевается международным стандартом. Право страныимпортера определять его собственный приемлемый уровень защиты является важным самостоятельным правом, а не исключением из общего обязательства по ст. $3.1^{1}$.

Меры, принимаемые страной-импортером, должны соответствовать требованиям ст. 3.3 и ст. 5 Соглашения.

Страна-импортер вправе самостоятельно определять приемлемый для себя уровень санитарной или фитосанитарной защиты, которого она намерена достичь путем введения защитных мер, в том числе и более высокий уровень защиты, чем установлено действующими международными стандартамиㄹ․ При этом ст. 3.3 Соглашения требует, чтобы меры, результатом введения которых будет более высокий уровень защиты, не противоречили прочим положениям Соглашения, в том числе ст. 5.

Соответствие принимаемых мер требованиям ст. 5.1 было предусмотрено как фактор, уравновешивающий право страны-импортера устанавливать свой уровень защиты. Требование проведения оценки риска в соответствии со ст. 5.1, так же как и необходимость получения значимых научных доказательств в соответствии со ст. 2.2, являются ключевыми для поддержания баланса между интересами развития международной торговли и защитой жизни и здоровья человека ${ }^{3}$.

Право принять временные меры (ст. 5.7 Соглашения).

Для принятия временных мер необходимо одновременное соблюдение четырех

\footnotetext{
${ }_{1}^{1}$ Дело DS26 Европейский союз - гормоны.

2 Дело DS26 Европейский союз - гормоны.

3 Дело DS26 Европейский союз - гормоны.
}

условий, установленных в ст. 5.7 и разъясненных позднее Апелляционным комитетом в деле Япония - сельхозпродукты II:

(I) меры принимаются в отношении ситуаций, когда не имеется соответствующих научных доказательств в достаточном объеме;

(II) меры принимаются на основании доступной информации, относящейся к рассматриваемой ситуации;

(III) страна-импортер, принимающая меры, стремится получить дополнительную информацию, необходимую для более объективной оценки риска;

(IV) страна-импортер, принявшая временные меры, пересматривает такие меры через определенный разумный промежуток времени с учетом вновь полученной информации в соответствии с положением III.

Если какое-либо из указанных выше требований не соблюдено, спорная мера будет считаться принятой с нарушением ст. 5.7 $7^{4}$.

Достаточность или недостаточность научных доказательств определяется не абстрактно, но «в свете конкретного вопроса», так как упоминание «относимости» и «недостаточности» во вводном предложении ст. 5.7 подразумевает наличие отношений между научными доказательствами и еще чем-то ${ }^{5}$. Апелляционный орган в своем докладе указывает, что «относящиеся к делу научные доказательства» будут считаться недостаточными для целей ст. 5.7, если основная часть доступных научных доказательств не позволяет ни количественно, ни качественно осуществить проведение адекватной оценки риска, как того требует ст. 5.1 и как определено в приложении А к Соглашению ${ }^{6}$. Важно, чтобы относимое доказательство, будь оно общего характера или относящееся к узкому вопросу, было достаточным для того, чтобы оценить вероятность проникновения, закрепления или распространения соответствующей угрозы в стране-импортере ${ }^{7}$.

Обязанность оценить риск. В соответствии с положениями ст. 5 для введения за-

\footnotetext{
${ }_{5}^{4}$ Дело DS245 Япония - импорт яблок (заявитель США). 5 Дело DS245 Япония - импорт яблок (заявитель США).

6 Дело DS245 Япония - импорт яблок (заявитель США). 7 Дело DS245 Япония - импорт яблок (заявитель США).
} 
щитных мер стране-импортеру необходимо оценить риск проникновения, закрепления или распространения соответствующей угрозы.

Использованная в Соглашении терминология на практике вызвала много вопросов, которые при рассмотрении споров были разрешены следующим образом:

1.1. Не требуется проведения полной оценки риска для введения минимального количественно измеримого значения величины риска ${ }^{1}$.

1.2. Установление минимальной величины риска (количественного определения риска) не является обязательным, но может быть произведено по желанию страныимпортера, проводящей оценку риска ${ }^{2}$.

1.3. В объем оценки риска могут входить факторы, не поддающиеся количественному анализу, проводимому опытными или экспериментальными лабораторными методами.

Некоторые виды факторов, перечисленные в ст. 5.2 как «соответствующие процессы или производственные методы» и «соответствующие методы наблюдения, отбора образцов и тестирования», не обязательно или полностью поддаются исследованию лабораторными методами, например, биохимии или фармакологии. Риск, подлежащий оценке в соответствии со ст. 5.1, это не только риск, поддающийся проверке в научной лаборатории в строго контролируемых условиях, но и риск в человеческих сообществах как таковых, иными словами «действительная возможность неблагоприятных последствий для здоровья человека в реальном мире» ${ }^{3}$.

1.4. Перечень данных, которые могут быть использованы при проведении оценки риска, указанный в ст. 5.2 Соглашения, не является закрытым ${ }^{4}$.

1.5. Общее обсуждение угрозы, от которой страна-импортер пытается защититься путем введения санитарных или фитосанитарных мер, не является оценкой риска по смыслу Соглашения 5 .

\footnotetext{
${ }^{1}$ Дело DS26 Европейский союз - гормоны.

2 Дело DS26 Европейский союз - гормоны.

3 Дело DS26 Европейский союз - гормоны.

4 Дело DS245 Япония - импорт яблок (заявитель США).

5 Дело DS245 Япония - импорт яблок (заявитель США).
}

В деле Европейский союз - гормоны Апелляционный орган указал следующее: для того чтобы провести оценку риска в соответствии с требованиями Соглашения, необходимо исследовать «канцерогенный потенциал не только соответствующих гормонов в общем, но и остатков тех гормонов, которые были обнаружены в мясе, полученном из скота, которому вводили гормоны для ускорения роста» 6 .

Для определения риска при проведении его оценки необходимо определить возможный вред (например, онкологические заболевания или генетические расстройства), а также установить точное вещество, которое может потенциально быть причиной такого вреда (например, конкретные гормоны, которые были использованы определенным образом для определенных целей) ${ }^{7}$.

В деле Япония - яблоки указано, что оценка риска заражения красной гнилью была основана на общей оценке возможных способов заражения, тогда как яблоки являются только одним из возможных переносчиков болезни. Научно доказано, указывается далее в докладе, что риск проникновения и распространения болезни существенным образом зависит от переносчика (растения). Поскольку оспариваемая мера относится к риску передачи красной гнили через яблоки, при рассмотрении вопроса о том, достаточно ли конкретна проведенная оценка риска, основным фактором, который необходимо учитывать, является природа риска, от наступления которого защищает оспариваемая мера. С учетом этого Апелляционный орган признал оценку рисков, проведенную в отношении всех возможных переносчиков болезни вместе, недостаточно конкретной ${ }^{8}$.

1.6. Оценка риска должна проводиться соответственно санитарной или фитосанитарной мере, которая может быть применена 9 .

При этом оценка риска не должна сводиться к исследованию исключительно уже принятой меры или меры, наиболее предпочтительной для введения (т.е. будет не-

\footnotetext{
${ }^{6}$ Дело DS26 Европейский союз - гормоны.

7 Дело DS26 Европейский союз - гормоны.

8 Дело DS245 Япония - импорт яблок (заявитель США).

9 Дело DS18 Австралия - импорт лосося (заявитель Канада).
} 
верным подгонять факты для обоснования уже принятой меры постфактум либо обосновывать какую-то отдельную меру) ${ }^{1}$.

1.7. Проводимая страной-импортером оценка риска, по смыслу ст. 5.1, должна ${ }^{2}$ :

1) включать оценку вероятности проникновения, закрепления или распространения заболевания;

2) быть проведена в соответствии с санитарными или фитосанитарными мерами, которые могут быть введены в таком случае;

3) определять заболевание, чье проникновение, закрепление или распространение на своей территории страна-импортер хочет предотвратить, а также возможные биологические и экономические последствия, связанные с проникновением, закреплением или распространением такого заболевания;

4) включать оценку вероятности проникновения, закрепления или распространения заболевания, а также связанные с этим биологические и экономические последствия;

5) включать оценку вероятности проникновения, закрепления или распространения заболевания соответственно санитарным и фитосанитарным мерам, которые могут быть применены.

Оценка риска, не соответствующая данным требованиям, не является оценкой риска по смыслу Соглашения, и, как следствие, введенная мера не основана на оценке риска ${ }^{3}$.

1.8. Результаты оценки риска должны достаточным образом обосновывать принятые меры ${ }^{4}$.

1.9. Риск, оцениваемый при проведении оценки, должен быть определенным риском, теоретические возможности («theoretical uncertainty») не могут быть предметом оценки ${ }^{5}$.

1.10. Страна-импортер вправе установить в качестве приемлемого «нулевой риск» ${ }^{6}$.

Определение адекватного уровня защииты (ст. 5.5 Соглашения).

В соответствии со ст. 5.5 Соглашения страна-импортер вправе установить для се-

\footnotetext{
${ }^{1}$ Дело DS18 Австралия - импорт лосося (заявитель Канада).

2 Дело DS245 Япония - импорт яблок (заявитель США), дело DS18 Австралия - импорт лосося (заявитель Канада).

3 Дело DS245 Япония - импорт яблок (заявитель США).

4 DS18 Австралия - импорт лосося (заявитель Канада).

5 DS18 Австралия - импорт лосося (заявитель Канада), дело DS26 Европейский союз - гормоны.

${ }^{6}$ DS18 Австралия - импорт лосося (заявитель Канада).
}

бя приемлемый уровень защиты, не нарушая при этом своих обязательств по Сoглашению.

Орган по регулированию споров при рассмотрении дела Европейский союз - гормоны, определил, что нарушением ст. 5.5 будет считаться одновременное наличие в действиях страны-импортера следующих трех элементов:

а) страна-импортер устанавливает различные приемлемые уровни защиты в нескольких сравнимых различных ситуациях.

Для целей ст. 5.5 различные ситуации являются сравнимыми, если они включают либо риск проникновения, закрепления или распространения одного и того же или схожих заболеваний, либо риск наступления одинаковых или схожих биологических или экономических последствий;

б) такие уровни защиты содержат необоснованные («arbitrary or unjustifiable») различия;

в) меры, включающие такие различия, в результате дискриминируют или скрытым образом ограничивают международную торговлю ${ }^{7}$.

Кроме того, было определено несколько дополнительных «предостерегающих» сигналов, свидетельствующих о наличии возможного нарушения ст. $5.5^{8}$ :

- необоснованный («arbitrary or unjustifiable)» характер различий в уровнях защиты;

- степень различий или величина несоответствий в уровнях защиты;

- несоответствие санитарных и фитосанитарных мер ст. 5.1 и 2.2 Соглашения. Вывод о том, что введение мер не основано на оценке рисков для жизни и здоровья человека, животных или растений (по причине отсутствия оценки риска как таковой или недостаточной оценки), сигнализирует о том, что введение мер не связано с защитой жизни и здоровья человека, животных или растений, но является способом ограничения международной торговли, принятым под видом санитарной или фитосани-

\footnotetext{
${ }^{7}$ Дело DS26 Европейский союз - гормоны.

8 Дело DS26 Европейский союз - гормоны, дело DS18 Австралия - импорт лосося (заявитель Канада).
} 
тарной меры, т.е. скрытым ограничением международной торговли ${ }^{1}$.

Например, в деле DS18 Австралия импорт лосося таким дополнительным сигналом был тот факт, что в качестве санитарной меры был запрещен импорт лосося. Однако был допустим импорт трески и ряда других товаров, при том что данное мероприятие создавало аналогичные риски. По мнению ОРС, концепция скрытого ограничения международной торговли включает среди прочего ограничения, устанавливающие необоснованные различия между определенными продуктами ${ }^{2}$.

Сами по себе данные сигналы не говорят о наличии нарушения, но в совокупности могут повлиять на вывод о наличии в принятых мерах скрытого ограничения международной торговли ${ }^{3}$.

Проведенный анализ норм Соглашения и практики их применения Органом по разрешению споров ВТО и Апелляцион- ным органом позволяет утверждать, что страна - член ВТО при наличии доказанной опасности какого-либо товара либо разумных оснований предполагать наличие такой опасности может запретить его импорт. При условии, что импорт запрещен или существенно ограничен на недискриминационной основе, у страны-импортера нет оснований опасаться сколь-нибудь существенных последствий такого запрета. Более того, даже если такой запрет будет впоследствии признан необоснованным ОРС ВТО и выводы доклада ОРС будут подтверждены Апелляционным органом, у страны-импортера есть достаточно времени для отмены такого запрета при отсутствии каких-либо санкций.

\title{
THE FOUNDATIONS AND PRINCIPLES OF APPLYING SANITARY AND PHYTOSANITARY MEASURES IN WORLD TRADE ORGANIZATION PRACTICE
}

\author{
M.S. Popov, A.Yu. Popova \\ Russian Medical Academy of Postgraduate Education, Russian Federation, \\ 2/1 Barrikadnaya St., Moscow, 123995
}

The performed analysis of the rules of the Agreement on the Application of Sanitary and Phytosanitary Measures and their application by the Dispute Settlement Body of the World Trade Organization (WTO) and the Appellate Body shows that a WTO member country may ban the import of goods if this product has been proven to be hazardous or there are reasonable grounds to assume that the product is hazardous. The requirement to perform risk assessment and the necessity to obtain "significant scientific evidence" are crucial to maintain the balance between the interests of developing international trade and that of human life and health protection. Provided that the import is banned or substantially restricted on a non-discriminatory basis, the importing country has no reasons to fear any significant effects from the ban. Furthermore, even if the ban is later found to be groundless, the importing country has sufficient time to cancel the ban in the absence of any sanctions.

Keywords: sanitary and phytosanitary measures, risk assessment, levels of protection.

(C) Popov M.S., Popova A.Yu., 2013

Popov Michael Sergeyevich - PhD. (e-mail mail@nnk.ru, tel.: 8 (495) 641-58 -72).

Popova Anna Yuryevna - DSc (Med), professor, Head of Department of organization of sanitary and epidemiological service (e-mail: rmapo@rmapo.ru, tel.: 8 (499) 458-95-63). 


\title{
ИСПОЛЬЗОВАНИЕ ДАННЫХ РЕГИОНАЛЬНОГО ИНФОРМАЦИОННОГО ФОНДА СГМ ДЛЯ ОЦЕНКИ РИСКА ЗДОРОВЬЮ НАСЕЛЕНИЯ Г. ЛИПЕЦКА
}

\author{
С.И. Савельев ${ }^{1,3}$, В.А. Бондарев 2,3 , Н.В. Нахичеванская², \\ М.Ф. Полякова ${ }^{2,3}$, Г.А. Юрьев ${ }^{2}$, В.М. Салтыков ${ }^{1,3}$, Е.А. Голованова ${ }^{1,3}$ \\ 1 Управление Роспотребнадзора по Липецкой области, Россия, 398002, г. Липецк, ул. Гагарина, 60-а \\ 2 Центр гигиены и эпидемиологии в Липецкой области, Россия, 398002, г. Липецк, ул. Гагарина, 60-а \\ ${ }^{3}$ Северо-Западный государственный медицинский университет им. И.И. Мечникова, Россия, \\ г. Санкт-Петербург, ул. Кирочная, 41
}

В современном промышленном центре, где географическое расположение предприятий, особенности ландшафта формируют в различных районах очаги экологического неблагополучия, существует проблема обоснованно выбирать территории и группы риска среди населения. Целью исследований являлось выявление риска нарушений здоровья населения г. Липецка под влиянием химических веществ, загрязняющих атмосферный воздух, и определение приоритетных направлений целевых программ, направленных на снижение техногенных загрязнений окружающей среды и риска нарушения здоровья населения. В результате исследования были интерполированы значения фоновых концентраций постов наблюдения для установления уровня риска и подтверждены расчетные данные реальными уровнями заболеваемости.

Ключевые слова: оценка риска, фоновые концентрации, региональный информационный фонд, социально-гигиенический мониторинг.

Среди факторов неблагоприятного воздействия окружающей среды на человека наибольшее беспокойство вызывает увеличивающееся загрязнение атмосферы из-за нарастающего объема эмиссии газов и аэрозолей антропогенного происхождения. Осуществление мер по оздоровлению воздушной среды связано с получением объективной информации об источниках и степени загрязнения воздуха [1].

Государственная система мониторинга в г. Липецке базируется на сети пунктов режимных наблюдений. Наблюдения за уровнем загрязнения атмосферного воздуха проводятся на 8 постах, на которых измеряются концентрации от 6 до 10 ингредиентов.

( Савельев С.И., Бондарев В.А., Нахичеванская Н.В., Полякова М.Ф., Юрьев Г.А., Салтыков В.М. Голованова Е.А., 2013

Савельев Станислав Иванович - доктор медицинских наук, профессор, заведующий кафедрой гигиены и эпидемиологии с основами лабораторного дела; руководитель Управления (e-mail: ocgsen@lipetsk.ru, тел.: 8 (4742) 27-00-76).

Бондарев Владимир Александрович - доктор медицинских наук, профессор, профессор кафедры гигиены и эпидемиологии с основами лабораторного дела; главный врач (e-mail: orgotdel@ fguz.lipetsk.ru, тел.: 8 (4742) 30-86-50).

Нахичеванская Наталия Владимировна - заведующая отделением социально-гигиенического мониторинга и оценки риска (e-mail: orgotdel@fguz.lipetsk.ru, тел.: 8 (4742) 30-86-98).

Полякова Марина Федоровна - кандидат медицинских наук, ассистент кафедры гигиены и эпидемиологии с основами лабораторного дела; заведующая отделом организационной деятельности, метрологии и экспертиз, социально-гигиенического мониторинга (e-mail: orgotdel@fguz.lipetsk.ru, тел.: 8 (4742) 30-86-65).

Юрьев Григорий Анатольевич - врач по общей гигиене отделения социально-гигиенического мониторинга и оценки риска (e-mail: orgotdel@fguz.lipetsk.ru, тел.: 8 (4742) 30-86-98).

Салтыков Вячеслав Михайлович - сотрудник кафедры гигиены и эпидемиологии с основами лабораторного дела; заместитель начальника отдела организации и обеспечения деятельности (e-mail: ocgsen@lipetsk.ru, тел.: 8 (4742) 3088-34).

Голованова Елена Алексеевна - сотрудник кафедры гигиены и эпидемиологии с основами лабораторного дела; заведующая отделом социально-гигиенического мониторинга (e-mail: ocgsen@lipetsk.ru, тел.: 8 (4742) 30-88-40). 
С 2011 г. системой постоянных мониторинговых исследований охвачена вся территория г. Липецка. Мониторинг атмосферного воздуха в городе осуществляет ФГБУ «Липецкий центр по гидрометеорологии и мониторингу окружающей среды». Маршрутный мониторинг проводился передвижной экологической лабораторией ОКУ «Гидротехнические комплексы» и лабораторией ФБУЗ «Центр гигиены и эпидемиологии в Липецкой области» в жилой зоне и под факелами промышленных предприятий.

Липецк является современным промышленным центром, в котором географическое расположение предприятий, особенности ландшафта и сезонных климатических изменений сформировали в различных районах несколько очагов экологического неблагополучия, имеющих индивидуальные наборы загрязнителей.

Предприятиями г. Липецка выброшено в атмосферный воздух 290 тыс. т загрязняющих веществ, что составляет $84 \%$ от общего количества выбросов в регионе. Максимальный вклад в загрязнение атмосферы в 2011 г. внесли ОАО «НЛМК» - 277,16 тыс. т, филиалы ООО «Газпромтрансгаз Москва» 34,3 тыс. т, ОАО «Липецкцемент» - 9,6 тыс. т, OAО «Квадра Генерирующая компания» филиал «Квадра» Восточная региональная генерация Липецкая ТЭЦ-2 - 1,8 тыс. т, ОАО «ЛМ3“ “Свободный сокол”»-1,4 тыс. т [4].

В 2011 г. количество автомобилей в г. Липецк возросло на 11 тыс. единиц по отношению к 2010 г. и составило 176,6 тыс. шт. Соответственно, увеличились и выбросы загрязняющих веществ с отработанными газами автотранспорта и составили 60 тыс. т.

Цель исследования - выявление приоритетных санитарно-эпидемиологических факторов, формирующих негативные тенденции в состоянии здоровья населения, для корректировки целевых программ по охране здоровья населения, оздоровлению среды обитания.

Материалы и методы исследования. Анализируемой средой был определен атмосферный воздух, а приоритетным путем по- ступления химических веществ в организм человека - ингаляционный. Оценка воздействующих концентраций проводилась на основании результатов лабораторного мониторинга объектов окружающей среды с постов наблюдения.

За основу был принят сценарий жилой зоны, при котором рассматривалось хроническое (пожизненное) воздействие, т.е. оценка воздействия на жителей, постоянно проживающих в рассматриваемой местности, без учета их дополнительной экспозиции к вредным веществам в процессе трудовой деятельности.

В данной работе характеристика канцерогенного и неканцерогенного рисков проводилась с использованием статистически обработанных среднегодовых концентраций, представленных ФГБУ «Липецкий центр по гидрометеорологии и мониторингу окружающей среды» и ОКУ «Гидротехнические комплексы» (табл. 1).

Расчет индивидуального канцерогенного риска $(C R)$ осуществлялся с использованием данных о величине экспозиции и значениях канцерогенного потенциала (табл. 2). Канцерогенный риск рассчитан по пяти канцерогенным веществам. Диапазон приемлемых канцерогенных рисков в соответствии с рекомендациями ВОЗ и комиссии Евросоюза был принят равным 1Е-06 [3].

Расчет неканцерогенных рисков проводился на основе коэффициента опасности $(H Q)$, представляющего собой соотношение между величиной экспозиции (суточной дозой, $A D D)$ и безопасным уровнем воздействия. За приемлемый, пренебрежимо малый неканцерогенный риск отдельных химических веществ принималась величина коэффициента опасности $H Q$, меньшая или равная 1,0. В качестве допустимой величины для групп веществ, воздействующих на одни и те же органы/системы организма, также принималось значение $H I=1,0$ [3].

Поскольку в данной работе предполагалось более детальное исследование рисков здоровью населения г. Липецка, то вся жилая городская застройка была условно разделена на зоны, соответствующие 
Таблица 1

Среднегодовые концентрации загрязняющих веществ по данным постов наблюдения за 2010-2012 гг.

\begin{tabular}{|c|c|c|c|c|}
\hline \multirow{2}{*}{$\begin{array}{l}\text { Номер поста } \\
\text { наблюдения }\end{array}$} & \multirow{2}{*}{$\begin{array}{c}\begin{array}{c}\text { Наименование } \\
\text { вещества }\end{array} \\
\end{array}$} & \multicolumn{3}{|c|}{ Среднегодовая концентрация, мг/м ${ }^{3}$} \\
\hline & & 2010 & 2011 & 2012 \\
\hline \multirow[t]{5}{*}{2} & Углерода оксид & 1 & 1 & 1 \\
\hline & Азота (IV) оксид & 0,01 & 0,01 & 0,01 \\
\hline & Сероводород & 0,001 & 0,001 & 0,001 \\
\hline & Фенол & 0,003 & 0,004 & 0,002 \\
\hline & Формальдегид & 0,008 & 0,005 & 0,007 \\
\hline \multirow[t]{7}{*}{3} & Углерода оксид & 1 & 1 & 1 \\
\hline & Азота (IV) оксид & 0,01 & 0,01 & 0,01 \\
\hline & Азота (II) оксид & 0,01 & 0,01 & 0,01 \\
\hline & Сероводород & 0,002 & 0,002 & 0,002 \\
\hline & Серы диоксид & 0,006 & 0,005 & 0,004 \\
\hline & Фенол & 0,003 & 0,004 & 0,002 \\
\hline & Бенз(а)пирен & 0,000002 & 0,0000016 & $0,0000017 *$ \\
\hline \multirow[t]{5}{*}{4} & Углерода оксид & 1 & 1 & 1 \\
\hline & Азота (IV) оксид & 0,01 & 0,01 & 0,01 \\
\hline & Сероводород & 0,002 & 0,002 & 0,002 \\
\hline & Фенол & 0,003 & 0,004 & 0,002 \\
\hline & Формальдегид & 0,007 & 0,005 & 0,006 \\
\hline \multirow[t]{9}{*}{5} & Углерода оксид & 2,15 & 1,09 & 1,02 \\
\hline & Азота (IV) оксид & 0,09 & 0,05 & 0,042 \\
\hline & Формальдегид & 0,015 & 0,01 & 0,008 \\
\hline & Серы диоксид & - & 0,018 & 0,0094 \\
\hline & Бензол & 0,018 & 0,038 & 0,033 \\
\hline & Ксилол (смесь изомеров о-, м-, п-) & 0,006 & 0,009 & 0,004 \\
\hline & Толуол & 0,015 & 0,02 & 0,011 \\
\hline & Этилбензол & 0,002 & 0,004 & 0,00088 \\
\hline & $\begin{array}{l}\text { Свинец и его неорганические соединения } \\
\text { (в пересчете на свинец) }\end{array}$ & 0,00009 & 0,00006 & 0,00015 \\
\hline \multirow[t]{6}{*}{6} & Углерода оксид & 1 & 1 & 1 \\
\hline & Азота (IV) оксид & 0,02 & 0,02 & 0,01 \\
\hline & Сероводород & 0,002 & 0,003 & 0,002 \\
\hline & Фенол & 0,002 & 0,004 & 0,002 \\
\hline & Формальдегид & 0,009 & 0,005 & 0,007 \\
\hline & Бенз(а) пирен & 0,00000172 & 0,0000015 & $0,0000017 *$ \\
\hline \multirow[t]{6}{*}{8} & Углерода оксид & 1 & 1 & 1 \\
\hline & Азота (IV) оксид & 0,01 & 0,02 & 0,01 \\
\hline & Сероводород & 0,002 & 0,002 & 0,002 \\
\hline & Фенол & 0,003 & 0,004 & 0,002 \\
\hline & Формальдегид & 0,007 & 0,004 & 0,006 \\
\hline & Бенз(а)пирен & 0,00000192 & 0,0000015 & $0,0000017^{*}$ \\
\hline \multirow[t]{5}{*}{9} & Углерода оксид & - & 1,49 & 1,28098 \\
\hline & Азота (IV) оксид & 0,038 & 0,0372 & 0,01909 \\
\hline & Сероводород & 0,003 & 0,0031 & 0,002 \\
\hline & Серы диоксид & 0,012 & 0,0128 & 0,0055 \\
\hline & Фенол & 0,00299 & 0,0029 & 0,00299 \\
\hline \multirow[t]{5}{*}{10} & Углерода оксид & 0,213 & 1 & 0,9963 \\
\hline & Азота (IV) оксид & 0,02 & 0,01 & 0,0118 \\
\hline & Сероводород & 0,003 & 0,003 & 0,0023 \\
\hline & Серы диоксид & 0,004 & 0,003 & 0,0034 \\
\hline & Фенол & 0,003 & 0,004 & 0,0022 \\
\hline
\end{tabular}

П р и м е ч а н и е. * По предварительным данным. 
территориям обслуживания поликлиник для взрослого и детского населения (рис. 1). Это позволило более дифференцированно подойти к интерполяции значений фоновых концентраций и повысить таким образом точность оценки риска для здоровья.

В наиболее густонаселенных жилых массивах в зонах обслуживания поликлиник на карту были нанесены реперные точки и проведены расчеты удаленных точек от постов наблюдения (рис. 2).
В этих точках проведена интерполяция фоновых концентраций загрязняющих веществ, используемых в дальнейшем для оценки риска. В пределах зоны наблюдений в городе значения фона как средней концентрации и коэффициента вариации могут быть получены интерполяцией их данных, полученных на стационарных постах [2]. Интерполяция значений осуществлялась в геоинформационной системе (ГИС) «Панорама-2011» и рассчитывалась отдельно для градаций скорости ветра 0-2 и 3-5 м/с.

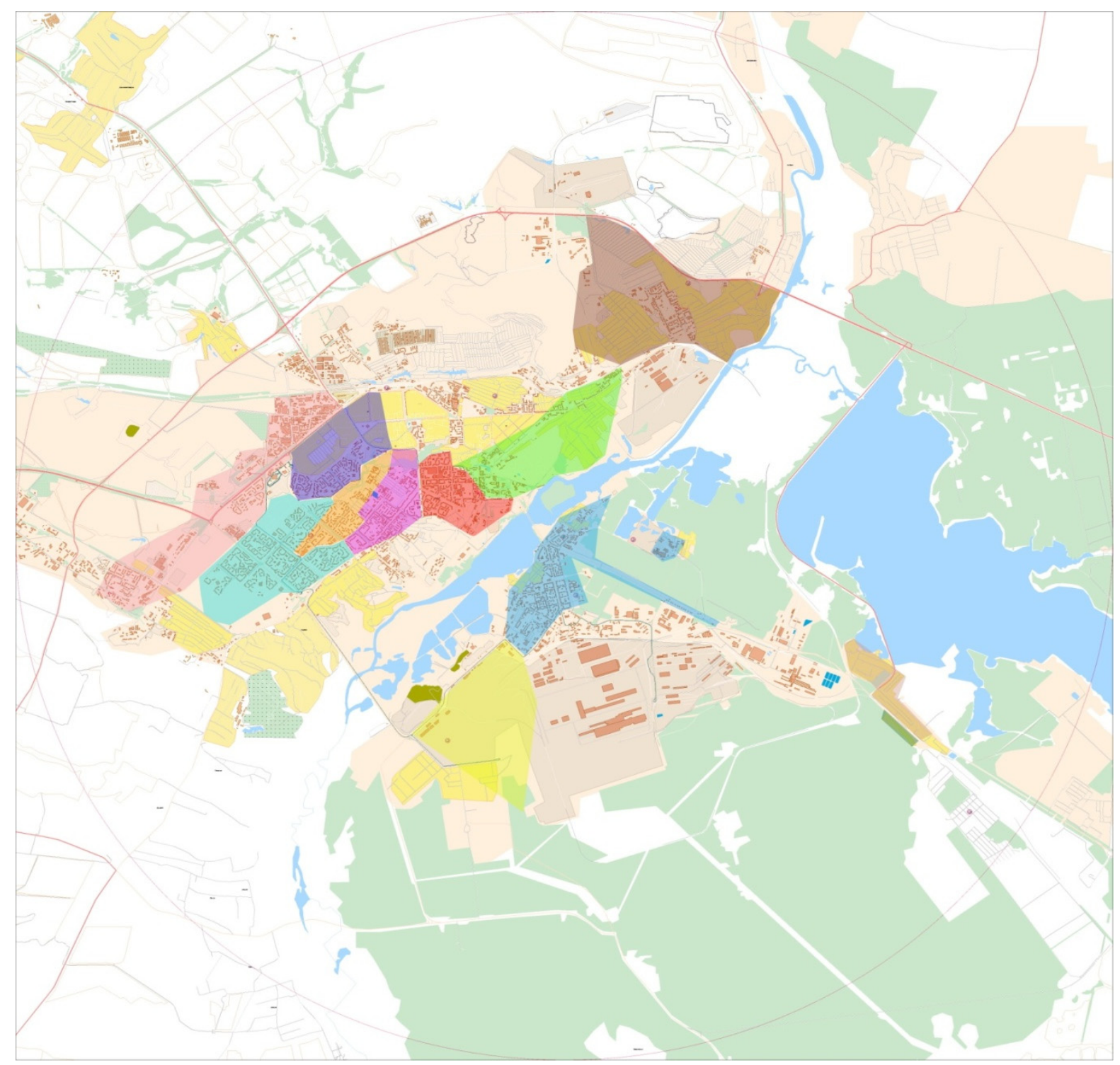

Рис. 1. Карта-схема г. Липецка с указанием зон обслуживания городских поликлиник 


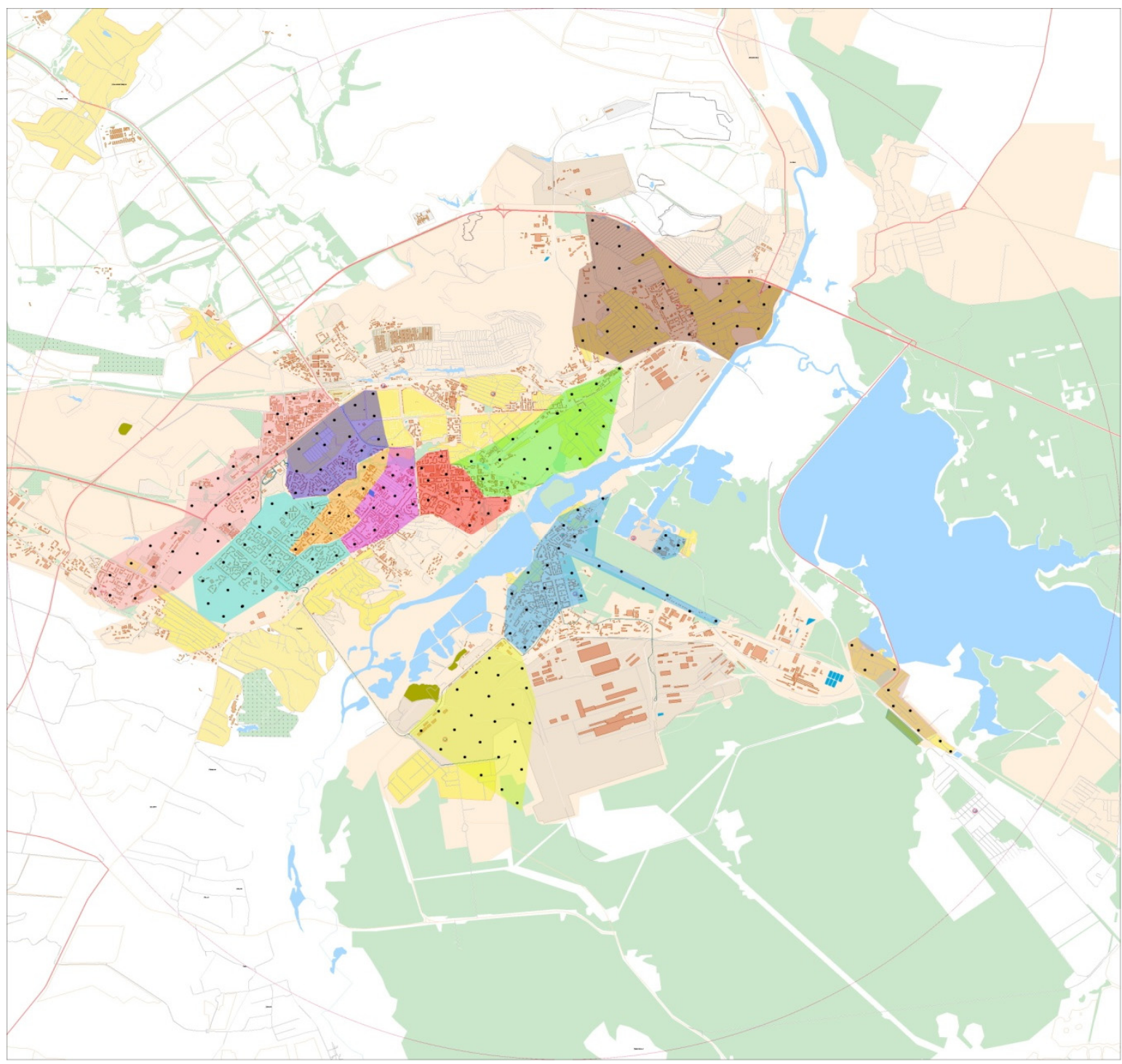

Рис. 2. Реперные точки в зонах обслуживания поликлиник

На карту г. Липецка были геокодированы посты наблюдения ФГБУ «Липецкий центр по гидрометеорологии и мониторингу окружающей среды», ОКУ «Гидротехнические комплексы» и ФБУЗ «Центр гигиены и эпидемиологии Липецкой области». Используя методику РД 52.04.186-89 «Руководство по контролю загрязнения атмосферы» (п. 9.8.3), был определен «центр тяжести» сети постов наблюдений, т.е. точка, координаты которой представляют собой среднее арифметическое соответствующих координат постов наблюдений. Затем определен пост, максимально удаленный от центра тяжести, и из центра тяжести провели окружность радиусом $1,1 R$ (рис. 3 ).

Расчет интерполяции фона осуществлялся по формуле

$$
C_{\phi}=\frac{\sum C_{\phi k} / r_{k}}{\sum 1 / r_{k}},
$$

где $C_{\phi k}$ и $C_{\phi}-$ фоновые концентрации на $k$-м посту наблюдения и в рассматриваемой точке (для соответствующей градации скорости и направления ветра); $r_{k}$ - расстояние от рассматриваемой точки до $k$-го поста. 


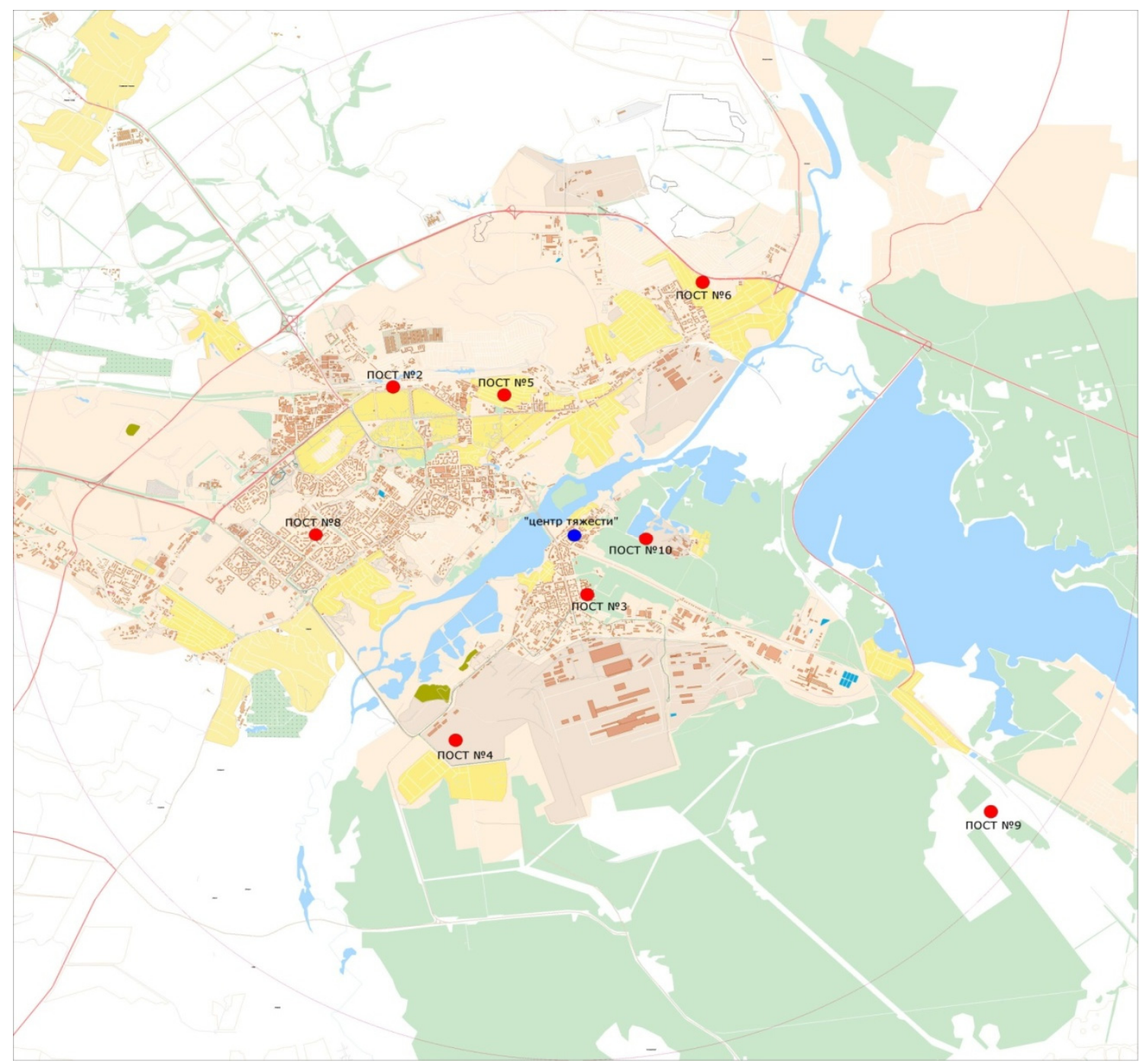

Рис. 3. Определение «центра тяжести» сети постов наблюдений

При проведении расчетов было принято во внимание, что при удалении местоположения исследуемой точки от ближайших постов более чем на 5 км детализация фона по направлениям ветра нецелесообразна, так как локальные условия могут внести существенные изменения в зависимости уровня загрязнения от направления ветра, и погрешность определения интерполированного значения фона может оказаться большей, чем погрешность от неучета влияния направления ветра [2]. На основании полученных результатов был выполнен анализ канцерогенного и неканцерогенного рисков. Анализ неканцерогенного риска проведен на основе определения суммарного индекса опасности для веществ с однонаправленным действием для хронических эффектов.
Результаты исследования. Результаты оценки риска для здоровья, выполненной по классической схеме, показали, что в 2010 г. уровень канцерогенного риска для взрослого населения по всем веществам относится ко второму и третьему диапазонам, а канцерогенный риск для детского населения - к первому и второму диапазонам. В 2012 г. уровень индивидуального канцерогенного риска для детского населения по всем веществам (за исключением этилбензола) относится к первому диапазону, а риск развития канцерогенных веществ от воздействия этилбензола - ко второму. В отношении взрослого населения отмечается снижение уровня канцерогенного риска до второго диапазона (за исключением этилбензола). Индивидуальный риск для взрос- 
лого населения по этилбензолу, напротив, увеличился до третьего диапазона.

Суммарный канцерогенный риск по 5-му, 6-му и 8-му постам в 2012 г. по сравнению с 2010 г. снизился как для взрослого, так и для детского населения (табл. 3).

Основной вклад в формирование риска развития канцерогенных эффектов на всей территории города вносят формальдегид и этилбензол.

Представленные данные (табл. 4) показывают, что неканцерогенный риск для взрослого населения превышает единицу по таким веществам, как формальдегид, бенз(а)пирен, сероводород, азота (IV) оксид.

Результаты расчета уровней риска, полученные с применением интерполированных значений фоновых концентраций, показали, что в настоящее время уровни индивидуального канцерогенного риска во всех зонах экологически неблагополучных планировочных районов находятся в диапазоне 7,47E-05...3,61E-04, что соответствует второму и третьему диапазо-

Таблица 2

Результаты расчетов индивидуального канцерогенного риска

\begin{tabular}{|c|c|c|c|c|c|c|c|}
\hline \multirow{2}{*}{$\begin{array}{c}\text { Номер } \\
\text { поста } \\
\text { наблюдения }\end{array}$} & \multirow{2}{*}{$\begin{array}{c}\text { Наименование } \\
\text { вещества }\end{array}$} & \multicolumn{2}{|c|}{2010} & \multicolumn{2}{|c|}{2011} & \multicolumn{2}{|c|}{2012} \\
\hline & & $C R$ взрослые & $C R$ дети & $C R$ взрослые & $C R$ дети & $C R$ взрослые & $C R$ дети \\
\hline 2 & Формальдегид & $1,01 \mathrm{E}-04$ & $8,07 \mathrm{E}-06$ & $6,30 \mathrm{E}-05$ & $5,04 \mathrm{E}-06$ & $8,82 \mathrm{E}-05$ & $4,60 \mathrm{E}-07$ \\
\hline 3 & Бенз(а)пирен & $2,14 \mathrm{E}-06$ & $1,71 \mathrm{E}-07$ & $1,71 \mathrm{E}-06$ & $1,37 \mathrm{E}-07$ & $1,82 \mathrm{E}-06^{*}$ & $1,45 \mathrm{E}-07 *$ \\
\hline 4 & Формальдегид & $8,82 \mathrm{E}-05$ & $7,06 \mathrm{E}-06$ & $6,30 \mathrm{E}-05$ & 5,04E-06 & $7,56 \mathrm{E}-05$ & $3,95 \mathrm{E}-07$ \\
\hline \multirow[t]{2}{*}{6} & Формальдегид & $1,13 \mathrm{E}-04$ & $9,07 \mathrm{E}-06$ & $6,30 \mathrm{E}-05$ & 5,04E-06 & $8,82 \mathrm{E}-05$ & $4,60 \mathrm{E}-07$ \\
\hline & Бенз(а)пирен & $1,84 \mathrm{E}-06$ & $1,47 \mathrm{E}-07$ & $1,60 \mathrm{E}-06$ & $1,28 \mathrm{E}-07$ & $1,82 \mathrm{E}-06^{*}$ & $1,45 \mathrm{E}-07 *$ \\
\hline \multirow[t]{2}{*}{8} & Формальдегид & $8,82 \mathrm{E}-05$ & $7,06 \mathrm{E}-06$ & $5,04 \mathrm{E}-05$ & $4,03 \mathrm{E}-06$ & $7,56 \mathrm{E}-05$ & $3,95 \mathrm{E}-07$ \\
\hline & Бенз(а)пирен & $2,05 \mathrm{E}-06$ & $1,64 \mathrm{E}-07$ & $1,60 \mathrm{E}-06$ & $1,28 \mathrm{E}-07$ & $1,82 \mathrm{E}-06^{*}$ & $1,45 \mathrm{E}-07 *$ \\
\hline \multirow[t]{4}{*}{5} & Формальдегид & $1,89 \mathrm{E}-04$ & $9,86 \mathrm{E}-07$ & $1,26 \mathrm{E}-04$ & $1,01 \mathrm{E}-05$ & $1,01 \mathrm{E}-04$ & $5,26 \mathrm{E}-07$ \\
\hline & Бензол & $1,33 \mathrm{E}-04$ & 1,07E-05 & $2,81 \mathrm{E}-04$ & $2,25 \mathrm{E}-05$ & 9,28E-07 & 7,43E-08 \\
\hline & Этилбензол & $2,11 \mathrm{E}-06$ & $1,69 \mathrm{E}-07$ & $4,22 \mathrm{E}-06$ & $3,38 \mathrm{E}-07$ & $2,44 \mathrm{E}-04$ & $1,95 \mathrm{E}-05$ \\
\hline & $\begin{array}{l}\text { Свинец и его } \\
\text { неорганические } \\
\text { соединения } \\
\end{array}$ & 1,04E-06 & $8,28 \mathrm{E}-08$ & $6,90 \mathrm{E}-07$ & $5,52 \mathrm{E}-08$ & 1,73E-06 & $1,38 \mathrm{E}-07$ \\
\hline
\end{tabular}

Пр и мечан и е. * После получения окончательных результатов по постам наблюдения г. Липецка будут проведены перерасчеты уровней риска.

Таблица 3

Суммарный канцерогенный риск г. Липецка

\begin{tabular}{|c|c|c|c|c|c|c|}
\hline \multirow{2}{*}{$\begin{array}{c}\text { Номер поста } \\
\text { наблюдения }\end{array}$} & \multicolumn{2}{|c|}{2010} & \multicolumn{2}{c|}{2011} & \multicolumn{2}{c|}{2012} \\
\cline { 2 - 7 } & взрослые & дети & взрослые & дети & взрослые & дети \\
\hline 5 & $4,36 \mathrm{E}-04$ & $2,08 \mathrm{E}-05$ & $4,12 \mathrm{E}-04$ & $3,30 \mathrm{E}-05$ & $3,48 \mathrm{E}-04$ & $3,03 \mathrm{E}-05$ \\
\hline 6 & $1,15 \mathrm{E}-04$ & $9,22 \mathrm{E}-06$ & $6,46 \mathrm{E}-05$ & $5,17 \mathrm{E}-06$ & $9,00 \mathrm{E}-05$ & $6,06 \mathrm{E}-07$ \\
\hline 8 & $9,03 \mathrm{E}-05$ & $7,22 \mathrm{E}-06$ & $5,20 \mathrm{E}-05$ & $4,16 \mathrm{E}-06$ & $7,74 \mathrm{E}-05$ & $5,4 \mathrm{E}-07$ \\
\hline
\end{tabular}

Таблица 4

Результаты расчетов неканцерогенного риска

\begin{tabular}{|c|l|c|c|c|}
\hline \multirow{2}{*}{$\begin{array}{c}\text { Номер поста } \\
\text { наблюдения }\end{array}$} & \multicolumn{1}{|c|}{ Наименование вещества } & \multicolumn{3}{|c|}{$H Q$} \\
\cline { 2 - 5 } & \multicolumn{1}{|c|}{2} & 2010 & 2011 & 2012 \\
\hline 1 & & 3 & 4 & 5 \\
\hline \multirow{3}{*}{2} & $498:$ Углерода оксид & 0,33 & 0,33 & 0,33 \\
\cline { 2 - 5 } & 5: Азота (IV) оксид & 0,25 & 0,25 & 0,25 \\
\cline { 2 - 5 } & 438: Сероводород & 0,50 & 0,50 & 0,50 \\
\cline { 2 - 5 } & 512: Фенол & 0,50 & 0,67 & 0,33 \\
\cline { 2 - 5 } & 522: Формальдегид & 2,67 & 1,67 & 2,33 \\
\hline
\end{tabular}


Окончание табл. 4

\begin{tabular}{|c|c|c|c|c|}
\hline 1 & 2 & 3 & 4 & 5 \\
\hline \multirow[t]{7}{*}{3} & 498: Углерода оксид & 0,33 & 0,33 & 0,33 \\
\hline & 5: Азота (IV) оксид & 0,25 & 0,25 & 0,25 \\
\hline & 4: Азота (II) оксид & 0,17 & 0,17 & 0,17 \\
\hline & 438: Сероводород & 1,00 & 1,00 & 1,00 \\
\hline & 436: Серы диоксид & 0,12 & 0,05 & 0,08 \\
\hline & 512: Фенол & 0,50 & 0,67 & 0,33 \\
\hline & 48: Бенз(а)пирен & 2,00 & 1,60 & $1,7^{*}$ \\
\hline \multirow[t]{5}{*}{4} & 498: Углерода оксид & 0,33 & 0,33 & 0,33 \\
\hline & 5: Азота (IV) оксид & 0,25 & 0,25 & 0,25 \\
\hline & 438: Сероводород & 1,00 & 1,00 & 1,00 \\
\hline & 512: Фенол & 0,50 & 0,67 & 0,33 \\
\hline & 522: Формальдегид & 2,33 & 1,67 & 2,00 \\
\hline \multirow[t]{9}{*}{5} & 498: Углерода оксид & 0,72 & 0,36 & 0,34 \\
\hline & 5: Азота (IV) оксид & 2,25 & 1,25 & 1,05 \\
\hline & 522: Формальдегид & 5,00 & 3,33 & 2,67 \\
\hline & 436: Серы диоксид & - & 0,36 & 0,19 \\
\hline & 57: Бензол & 0,60 & 1,27 & 1,10 \\
\hline & 273: Ксилол (смесь изомеров о-, м-, п-) & 0,06 & 0,09 & 0,04 \\
\hline & 473: Толуол & 0,04 & 0,05 & 0,03 \\
\hline & 582: Этилбензол & 0,002 & 0,004 & 0,001 \\
\hline & $\begin{array}{l}\text { 433: Свинец и его неорганические } \\
\text { соединения (в пересчете на свинец) }\end{array}$ & 0,18 & 0,12 & 0,30 \\
\hline \multirow[t]{6}{*}{6} & 498: Углерода оксид & 0,33 & 0,33 & 0,33 \\
\hline & 5: Азота (IV) оксид & 0,50 & 0,50 & 0,25 \\
\hline & 438: Сероводород & 1,00 & 1,50 & 1,00 \\
\hline & 512: Фенол & 0,33 & 0,67 & 0,33 \\
\hline & 522: Формальдегид & 3,00 & 1,67 & 2,33 \\
\hline & 48: Бенз(а)пирен & 1,72 & 1,50 & $1,7^{*}$ \\
\hline \multirow[t]{6}{*}{8} & 498: Углерода оксид & 0,33 & 0,33 & 0,33 \\
\hline & 5: Азота (IV) оксид & 0,25 & 0,50 & 0,25 \\
\hline & 438: Сероводород & 1,00 & 1,00 & 1,00 \\
\hline & 512: Фенол & 0,50 & 0,67 & 0,33 \\
\hline & 522: Формальдегид & 2,33 & 1,33 & 2,00 \\
\hline & 48: Бенз(а)пирен & 1,92 & 1,50 & $1,7^{*}$ \\
\hline \multirow[t]{5}{*}{9} & 498: Углерода оксид & - & 0,50 & 0,43 \\
\hline & 5: Азота (IV) оксид & 0,95 & 0,93 & 0,48 \\
\hline & 438: Сероводород & 1,50 & 1,55 & 1,00 \\
\hline & 436: Серы диоксид & 0,24 & 0,26 & 0,11 \\
\hline & 512: Фенол & 0,50 & 0,48 & 0,50 \\
\hline \multirow[t]{5}{*}{10} & 498: Углерода оксид & 2,84 & 0,33 & 0,33 \\
\hline & 5: Азота (IV) оксид & 0,50 & 0,25 & 0,30 \\
\hline & 438: Сероводород & 1,50 & 1,50 & 1,15 \\
\hline & 436: Серы диоксид & 0,08 & 0,06 & 0,07 \\
\hline & 512: Фенол & 0,50 & 0,67 & 0,37 \\
\hline
\end{tabular}

Пр и м е ч а и е. *После получения окончательных результатов по постам наблюдения г. Липецка будут проведены перерасчеты уровней риска.

нам. Основной вклад в индивидуальный канцерогенный риск вносят этилбензол и формальдегид.

Иная ситуация складывается в отношении неканцерогенных эффектов. В связи с тем что на исследуемой территории имеет место многокомпонентное химическое загрязнение объектов окружающей среды, несомненный интерес представляло изучение суммарных рисков, обусловленных од- 
новременным воздействием сразу нескольких химических соединений. Индексы опасности были рассчитаны отдельно для двенадцати выделенных поражаемых систем организма на текущий момент. В табл. 5 приведены результаты анализа риска развития хронических эффектов по суммарному индексу опасности $H I$ для веществ с однонаправленным действием с градацией по зонам обслуживания поликлиник.

Как следует из данных, приведенных в табл. 5, во всех зонах обслуживания поликлиник уровни риска развития заболеваний органов дыхания, глаза, а также влияния на иммунитет превышают допустимые величины. Индексы опасности остальных девяти поражаемых систем организма (кровь, почки, печень, репродуктивная система, развитие, красный костный мозг, гормональная система) не превышают единицы.

Ведущими загрязнителями по неканцерогенным эффектам являются формальдегид, бен(а)пирен, сероводород, коэффициент опасности которых составляет 1,93, 1,7 и 1,15 соответственно. Наибольший вклад как в суммарную величину $H I$, так и в риск воздействия на органы дыхания вносит формальдегид.

Проведенный анализ общей заболеваемости населения на прилегающих территориях показал, что в оцениваемый период (2010-2012 гг.) общая заболеваемость по всем классам болезней среди детей (0-14 лет) выросла на территориях обслуживания: МУЗ «Городская больница “Свободный сокол”»; МУЗ «Детская городская поликлиника № 5»; МУ «Городская детская больница № 2». В остальных лечебных учреждениях, обслуживающих детское население, отмечается снижение общего количества заболеваний.

В 2012 г. в сравнении с 2010 г. среди детского населения отмечается рост заболеваемости по отдельным классам болезней, а именно: увеличилось количество зарегистрированных случаев заболеваний органов дыхания в МУ «Городская детская больница № 1» на 7,47 \%, в МУ «Городская детская больница № 2»- на $12,84 \%$, а также в МУЗ «Детская городская поликлиника № 5» и МУЗ «Городская больница "Свобод-

Таблица 5

Суммарные индексы опасности развития неканцерогенных хронических эффектов в 2012 г.

\begin{tabular}{|l|c|c|c|}
\hline \multirow{2}{*}{ Поликлиника, обслуживающая определенную территорию } & \multicolumn{3}{|c|}{ Индексы опасности } \\
\cline { 2 - 4 } & $\begin{array}{c}\text { Органы } \\
\text { дыхания }\end{array}$ & Глаза & Иммунитет \\
\hline МУ «Городская больница “Липецк-Мед”» & 3,59 & 2,00 & 2,00 \\
\hline МУ3 «Детская городская поликлиника № 5» & 3,67 & 1,71 & 1,52 \\
\hline МУ3 «Городская поликлиника № 3» & 3,94 & 2,41 & 2,39 \\
\hline МУ3 «Городская больница “Свободный Сокол”» & 3,91 & 4,03 & 2,33 \\
\hline МУ3 «Городская поликлиника № 2» & 3,42 & 2,31 & 2,31 \\
\hline Частное Учреждение «Учебно-производственный & 2,13 & 1,34 & 1,34 \\
\hline и медико-профилактический центр» & 3,89 & 2,67 & 2,67 \\
\hline МУ «Городская детская больница № 1» & 1,89 & 2,03 & 2,03 \\
\hline Некоммерческое партнерство «Новолипецкий медицинский центр» & 3,61 & 1,93 & 1,93 \\
\hline МУ3 «Городская поликлиника № 4» & 3,45 & 1,41 & 1,41 \\
\hline МУ «Городская детская больница № 2» & 3,59 & 3,71 & 2,33 \\
\hline МУ3 «Городская поликлиника № 6» & 3,57 & 1,96 & 1,96 \\
\hline МУ «Городская поликлиника № 1» & 3,44 & 3,31 & 2,17 \\
\hline МУ «Городская больница № 2» & 3,44 & 2,33 & 2,33 \\
\hline МУ «Городская больница № 5» & 3,34 & 2,13 & 2,13 \\
\hline МЛПУ «Городская поликлиника № 5» & 1,88 & 1,12 & 1,12 \\
\hline МУ3 «Городская поликлиника № 8» & 3,23 & 2,12 & 2,12 \\
\hline МУ3 «Городская больница № 3» & & & \\
\hline
\end{tabular}


ный сокол”» на 11,63 и 28,79 \% соответственно.

Увеличение случаев злокачественных новообразований отмечается на территории обслуживания МУ «Городская детская больница № 2», МУЗ «Детская городская поликлиника № 5», МУЗ «Городская больница “Свободный сокол”».

Общая заболеваемость по всем классам болезней среди подросткового (15-17 лет) населения выросла на территории обслуживания МУ «Городская детская больница № 2». По остальным лечебным учреждениям, обслуживающим подростковое население, выявлено снижение общего количества заболеваний. По отдельным классам болезней среди подростков отмечается рост в 2012 г. по сравнению с 2010 г.:

- болезней органов дыхания на территории обслуживания МУЗ «Детская городская поликлиника № 5»;

- злокачественных новообразований на территории обслуживания МУ «Городская детская больница № 2», МУ «Городская больница "Липецк-Мед"».

Общая заболеваемость по всем классам болезней среди взрослого (18 лет и старше) населения выросла на территории обслуживания МУЗ «Городская поликлиника № 6». На территории, обслуживаемой МУЗ «Городская поликлиника № 4», заболеваемость осталась на прежнем уровне. По остальным лечебным учреждениям, обслуживающим взрослое население, отмечается снижение общего количества заболеваний. Однако среди взрослого населения по отдельным классам болезней наблюдается рост заболеваемости в 2012 г. по сравнению с 2010 г.:

- болезнями органов дыхания на территории обслуживания МУЗ «Городская поликлиника № 4», МУ «Городская поликлиника № 1», МУЗ «Городская поликлиника № 6», МЛПУ «Городская поликлиника № 5, МУЗ «Городская поликлиника № 3»;
- злокачественными новообразованиями на территории обслуживания МУ «Городская поликлиника № 1», МЛПУ «Городская поликлиника № 5», МУЗ «Городская поликлиника № 3», МУ «Городская больница № 2» и МУ «Городская больница “Липецк-Мед"».

Понимая, что конкретные численные значения риска, установленные в настоящей работе, имеют относительный характер и могут рассматриваться только в контексте всех факторов неопределенности, выявленных в исследовании, а также многих неучтенных факторов, влияющих на качество окончательных оценок, можно утверждать, что они тем не менее отражают количественные характеристики потенциального ущерба здоровью от воздействия различных химических веществ в г. Липецке и тенденции его формирования.

Выводы. Таким образом, на основании данных социально-гигиенического мониторинга проведена количественная оценка негативного воздействия загрязнения атмосферного воздуха на здоровье населения. Установленные уровни индивидуального канцерогенного и неканцерогенного рисков для различных возрастных групп населения г. Липецка позволяют откорректировать мероприятия областных целевых программ по выявленным приоритетным направлениям, обеспечить информационную поддержку принятия управленческих решений в сфере обеспечения санитарно-эпидемиологического благополучия населения и их эффективность.

Данное исследование позволит реализовывать комплекс адресных мероприятий по реабилитации населения с высоким уровнем риска развития экологически обусловленных нарушений здоровья и обоснованно выбирать территории и группы риска среди населения для последующей реабилитации.

\section{Список литературы}

1. Фомин Г.С., Фомина О.Н. Воздух. Контроль загрязнения по международным стандартам: справочник. 2-е изд., перераб. и доп. - М.: Протектор, 2002. - 432 с.

2. РД 52.04.186-89. Руководство по контролю загрязнения атмосферы [Электронный ресурс]. - URL: http: // www.gosthelp.ru/ text/RD520418689 Rukovodstvopok.html (дата обращения: 23.11. 2002). - M., 1991. 
3. Р 2.1.10.1920-04. Руководство по оценке риска для здоровья населения при воздействии химических веществ, загрязняющих окружающую среду. [Электронный pecypc]. - URL: http: //www.znaytovar.ru/ gost/2/R_2110192004_Rukovodstvo_po_oc.html (дата обращения: 6.05. 2007).

\section{References}

1. Fomin G.S., Fomina O.N. Vozdukh. Kontrol' zagryazneniya po mezhdunarodnym standartam. Spravochnik [Air. Pollution monitoring according to international standards. A reference book]. Ed. 2. Moscow: Protektor, 2002. $432 \mathrm{p}$.

2. RD 52.04.186-89. Rukovodstvo po kontrolyu zagryazneniya atmosfery [RD 52.04.186-89. Guidelines for ambient air pollution control]. Available at: http: // www.gosthelp.ru/ text/RD520418689 Rukovodstvopok.html.

3. R 2.1.10.1920-04. Rukovodstvo po otsenke riska dlya zdorov'ya naseleniya pri vozdeystvii khimicheskikh veshchestv, zagryaznyayushchikh okruzhayushchuyu sredu [R 2.1.10.1920-04. Guidelines for human health risk assessment of exposure to environmental chemical pollutants]. Available at: http: //www.znaytovar.ru/ gost/2/R_2110192004_Rukovodstvo_po_oc.html.

\section{USING DATA FROM A REGIONAL INFORMATION FUND OF SOCIAL AND ENVIRONMENTAL HEALTH MONITORING TO ASSESS HUMAN HEALTH RISKS IN LIPETSK}

\section{S.I. Savelyev1,3, V.A. Bondarev2,3, N.V. Nakhichevanskaja2, M.F. Polyakova2,3, G.A. Yuriev ${ }^{1,3}$, V.M. Saltykov ${ }^{1,3}$, E.A. Golovanova ${ }^{1,3}$}

1 The Lipetsk Region Department of the Federal Service on Customers Rights Protection and Human Well-Being Surveillance, Russian Federation, 60-a Gagarin St., Lipetsk, 398002, 2 Lipetsk Region Center for Hygiene and Epidemiology, Russian Federation, 60-a Gagarin St., Lipetsk, 398002, 3 I.I. Mechnikov Northwestern State Medical University, Russian Federation, 41 Kirochnaya st., St. Petersburg, 191015

In a modern industrial center, where the geographical location of industrial companies and landscape features cause environmentally unfavorable conditions in certain parts of the city, there is a problem when reasonably selecting areas and population groups at risk. The aim of this study was to identify the risk of health disorders in Lipetsk citizens who are exposed to chemical pollutants of ambient air and to determine the major directions for target programs aimed at reducing technogenic pollution of the environment and human health risks. The study resulted in the interpolation of the values of background concentrations from monitoring stations to determine risk levels and in the confirmation of the calculated data by actual disease incidence rates.

Keywords: risk assessment, background concentrations, regional information fund, social and environmental health monitoring.

(C) Savelyev S.I., Bondarev V.A., Nakhichevanskaja N.V., Polyakova M.F., Yuriev G.A., Saltykov V.M., Golovanova E.A., 2013

Savel'ev Stanislav Ivanovich - Dsc (Med), professor, Head of Department of hygiene and epidemiology with the basics of laboratory works; Director (e-mail: ocgsen@ lipetsk.ru, tel.: 8 (4742) 27-00-76).

Bondarev Vladimir Alexandrovich - DSc (Med), professor, professor of Department of hygiene and epidemiology with the basics of laboratory works; head doctor (e-mail: orgotdel@fguz.lipetsk.ru, tel.: 8 (4742) 30-86-50).

Nahichevanskaya Nataliya Vladimirovna - Head of Department of social-hygienic monitoring and risk assessment (e-mail: orgotdel@fguz.lipetsk.ru, tel.: 8 (4742) 30-86-98).

Polyakova Marina Fedorovna - PhD, assistant of Department of hygiene and epidemiology with the basics of laboratory works; Head of Department of organizational activity, metrology and expertise, social-hygienic monitoring (e-mail: orgotdel@fguz.lipetsk.ru, tel.: 8 (4742) 30-86-65).

Yur'ev Grigoriy Anatol'evich - doctor of common hygiene of Department of social-hygienic monitoring and risk assessment (e-mail: orgotdel@ fguz.lipetsk.ru, tel.: 8 (4742) 30-86-98).

Saltykov Vyacheslav Mihaylovoch - fellow of Department of hygiene and epidemiology with the basics of laboratory works; deputy director of Department of organization and delivery of activity (e-mail: ocgsen@lipetsk.ru, tel.: 8 (4742) 30-88-34).

Golovanova Elena Alexseevna - fellow of Department of hygiene and epidemiology with the basics of laboratory works; head of Department of social-hygienic monitoring (e-mail: ocgsen@lipetsk.ru, tel.: 8 (4742) 30-88-40). 
УДК 614.78

\title{
ГИГИЕНИЧЕСКОЕ ОБОСНОВАНИЕ ПРОФИЛАКТИЧЕСКИХ МЕР ДЛЯ ОБЕСПЕЧЕНИЯ НАСЕЛЕНИЯ Г. САНКТ-ПЕТЕРБУРГА ПИТЬЕВОЙ ВОДОЙ ВЫСОКОГО КАЧЕСТВА
}

\author{
Н.В. Ерастова, А.В. Мельцер \\ Управление Федеральной службы по надзору в сфрере защиты прав потребителей \\ по городу Санкт-Петербургу, Россия, 191025, г. Санкт-Петербург, ул. Стремянная, 19
}

\begin{abstract}
Высокое качество питьевой воды является результатом комплексного решения ряда задач, основными из которых являются разработка и внедрение современных технологий водоочистки, использование эффективных механизмов лабораторного контроля, социально-гигиенического мониторинга, интегрального подхода к оценке качества питьевой воды, использование гигиенически обоснованных решений в части водоснабжения и водоотведения.
\end{abstract}

Ключевые слова: оценка риска, интегральная оценка питьевой воды, безвредность питьевой воды.

Обеспечение населения питьевой водой гарантированного качества с целью профилактики инфекционной и неинфекционной заболеваемости, связанной с водным фактором, является одним из приоритетных направлений обеспечения стандартов качества проживания. Требуемое качество питьевой воды достигается за счет комплексного решения ряда задач, из которых основными являются разработка и внедрение современных технологий водоочистки, эффективных механизмов производственного лабораторного контроля, социально-гигиенического мониторинга, интегрального подхода к оценке качества питьевой воды [1, 3], использование гигиенически обоснованных решений в части водоснабжения и водоотведения.

В г. Санкт-Петербург реализация этих направлений осуществляется путем тесного взаимодействия Управления Роспотребнадзора по г. Санкт-Петербургу (далее - Управление) и ГУП «Водоканал Санкт-Петербурга». Для оценки качества питьевой воды сформирован общий банк результатов исследований, выполненных в рамках социально-гигиенического мониторинга и производственного контроля ГУП «Водоканал Санкт-Петербурга» на всех стадиях водоподготовки (источник, выход со станции водоподготовки, распределительная сеть).
Общий банк включает результаты лабораторных исследований, выполняемые в 228 точках Управления и 174 точках ГУП «Водоканал Санкт-Петербурга», что позволяет принимать своевременные решения для регулирования процессов водоподготовки. Общее количество исследований составляет более 90 тыс. в год.

Исходным сырьем для приготовления питьевой воды в г. Санкт-Петербург является вода из поверхностного источника водоснабжения - реки Невы, водозаборы которой обеспечивают $98 \%$ потребности города в воде. Вода в Неве относится к природным водам повышенной цветности в пределах 20-60 градусов, обусловленной содержанием сложных гуминовых веществ торфяного происхождения [3, 5, 6]. Другой особенностью невской воды является ее слабая минерализация, в том числе низкое содержание кальция и магния. Сезонные изменения качества воды касаются в основном мутности, цветности, окисляемости и щелочности $[5,6]$. В соответствии с классификацией по ГОСТ 2761-84 «Источники

(C) Ерастова Н.В., Мельцер А.В., 2013

Ерастова Наталья Вячеславовна - начальник информационно-аналитического отдела (e-mail: Erastova_NV@ 78.rospotrebnadzor.ru, тел.: 8 (812) 572-48-29).

Мельцер Александр Виталиевич - доктор медицинских наук, заместитель руководителя (е-mail: uprav@78.rospotrebnadzor.ru, тел.: 8 (812) 764-54-38). 
централизованного хозяйственно-бытового водоснабжения. Гигиенические, технические требования и правила выбора» река Нева как источник централизованного водоснабжения относится к III классу. Водоснабжение г. Санкт-Петербург построено по принципу территориального зонирования. В каждой из зон имеются водозаборные и водоочистные сооружения, повысительные станции и системы распределения воды. Сформированы и развиваются три зоны водоснабжения города с пятью крупными станциями водоподготовки, осуществляющими водозабор из реки Невы: Главной, Южной, Северной, Волковской и Корчмино $[3,5,6]$.

Результаты мониторинга показывают, что доля проб питьевой воды, не отвечающих гигиеническим требованиям, в г. СанктПетербург значительно ниже, чем в Российской Федерации. В 2011 г. удельный вес неудовлетворительных проб питьевой воды в городе составил по санитарно-химическим показателям 5,63 \% против $16,9 \%$ в Российской Федерации, по микробиологическим показателям - 0,13\% против 4,6\% в Российской Федерации. Имеющиеся отклонения от гигиенических нормативов по санитарно-химическим показателям обусловлены повышенным содержанием железа, мутностью и цветностью - показателями органолептического механизма воздействия.

Обеспечение требуемого качества питьевой воды явилось результатом разработки Управлением, ГУП «Водоканал Санкт-Петербурга» и правительством Санкт-Петербурга мероприятий по улучшению водоснабжения города. Приняты и реализуются региональные целевые программы, направленные на обеспечение населения питьевой водой, отвечающей гигиеническим нормативам: «Программа комплексного развития систем коммунальной инфраструктуры Санкт-Петербурга по разделам электро-, тепло-, водоснабжение, водоотведение до 2015 г.», «Программа прекращения сброса сточных вод без очистки в водные объекты на
2006-2015 гг.», программа «Чистая вода Санкт-Петербурга» на 2011-2025 гг. и др. [6].

В рамках реализации программ ГУП «Водоканал Санкт-Петербурга» выполнен ряд гигиенически обоснованных мероприятий, позволивших обеспечить нормативное качество питьевой воды, в том числе осуществлена модернизация системы реагентной обработки; наряду с ультрафиолетовым обеззараживанием вводится предварительное озонирование воды для более глубокой очистки от бактериального и вирусного загрязнения. Использование системы дозирования порошкообразного активированного угля позволяет в процессе водоподготовки обеспечивать удаление органических веществ - одорантов и нефтепродуктов, а также снизить окисляемость. Завершено введение системы автоматического дозирования флокулянта для совершенствования процессов очистки воды из поверхностного источника; внедрена технология кондиционирования воды на осветительных фильтpax, обеспечивающая снижение содержания железа и улучшение органолептических показателей. Особое внимание уделено контролю качества воды на всех этапах водоподготовки, в том числе запущена автоматизированная система контроля качества воды с максимальной автоматизацией технологических процессов и использованием приборов онлайн контроля. Для немедленного обнаружения токсичных веществ, превышающих фоновые значения в воде водоисточника, используется система биомониторинга [5, 6].

Результатом скоординированной работы Управления и ГУП «Водоканал СанктПетербурга» стало значительное улучшение показателей безопасности и безвредности питьевой воды. Созданная система водоподготовки и контроля питьевой воды в первую очередь положительно сказалась на уровне инфекционной заболеваемости. Заболеваемость дизентерией снизилась с 22,6 на 100 тыс. человек населения в 2005 г. до 11,4 на 100 тыс. человек населения в 2011 г., т.е. в 2 раза. Заболеваемость вирусным гепатитом А по сравнению 
с 2005 г. снизилась в 30 раз. В 2011 г. показатель заболеваемости составил 3,33 на 100 тыс. населения, что в 1,3 раза ниже уровня заболеваемости в Российской Федерации [6]. Исходя из анализа динамики показателей водно-обусловленной инфекционной заболеваемости, в частности вирусным гепатитом А и дизентерией, можно констатировать, что питьевая вода, подаваемая в разводящую сеть города, безопасна для здоровья населения и не является фактором передачи инфекционных заболеваний на протяжении многих лет.

Существующее состояние химического загрязнения питьевой воды не оказывает существенного негативного влияния на здоровье населения, что было подтверждено интегральной оценкой питьевой воды, выполненной Управлением совместно с ГБОУ ВПО «Северо-Западный государственный медицинский университет им. И.И. Мечникова» в соответствии с методическими рекомендациями МР 2.1.4.0032-11 «Интегральная оценка питьевой воды централизованных систем водоснабжения по показателям химической безвредности» $[1,3]$. Интегральная оценка питьевой воды позволила нам не только проследить динамику изменения качественных характеристик питьевой воды на всех этапах производства и транспортировки с позиции риска здоровью, но и оценить эффективность технологических решений на водопроводных станциях г. Санкт-Петербург, определить приоритеты и разработать предложения для оптимальной реализации технологических решений ГУП «Водоканал Санкт-Петербурга» [3]. Проведенная работа подтвердила гигиеническую обоснованность и эффективность реализуемых ГУП «Водоканал СанктПетербурга» мероприятий и целесообразность совершенствования технологии водоподготовки, а также позволила определить наиболее эффективные направления модернизации водохозяйственного комплекса [1].

Основным мероприятием является переход на использование современных технологий водоподготовки с полным отказом от использования одноступенной схемы очистки. Реализуемая двухступенная технология водоподготовки, включающая предварительное озонирование, коагуляцию, отстаивание в отстойниках с тонкослойными модулями (полочный отстойник), фильтрацию на скорых фильтрах; двухступенное обеззараживание: хлораминами и ультрафиолетом; обработку промывной воды на полочном отстойнике со встроенным илоуплотнителем и обезвоживание осадка на центрифугах, наиболее эффективна и является одной из наилучших доступных технологий для водоподготовки в условиях использования воды из поверхностного источника реки Невы [5]. На основании полученных в ходе работы материалов в настоящее время ГУП «Водоканал Санкт-Петербурга» выполняется разработка Регламента оценки питьевой воды на выходе со станций водоподготовки по показателям химической безвредности.

Однако имеется ряд нерешенных вопросов, касающихся обеспечения населения г. Санкт-Петербург доброкачественной и полезной питьевой водой и требующих комплексного подхода и скорейшего решения:

1. Неудовлетворительная ситуация с состоянием основного источника водоснабжения реки Невы. Результаты лабораторного контроля свидетельствуют о стабильно высоком удельном весе неудовлетворительных проб воды в Неве. В 2011 г. доля проб воды из реки Невы, не соответствующих нормативам, составила по микробиологическим показателям $87,1 \%$ против $21,2 \%$ в Российской Федерации (2009 г.), по санитарно-химическим показателям - 44,4\% против 16,2\% в Российской Федерации (2009 г.).

Основной причиной неудовлетворительного качества воды в Неве является ее антропогенное загрязнение: сброс загрязняющих веществ предприятиями четырех субъектов Российской Федерации; неудовлетворительное содержание береговых зон; сброс неочищенных или недостаточно очищенных стоков через выпуски хозяйственно-бытовой и ливневой канализации 
объектов г. Санкт-Петербург и Ленинградской области, смыв загрязнений с городских и сельских водосборных территорий; нарушения режима зон санитарной охраны $[5,6]$. Высокое загрязнение воды в Неве ставит вопрос о необходимости продолжения масштабных мероприятий водоподготовки, своевременной модернизации технологий очистки на городских водопроводных станциях, а высокое бактериальное загрязнение требует специальных методов многоступенчатой водоподготовки для ее обеззараживания.

2. В ряде районов г. Санкт-Петербург в питьевой воде отмечаются превышения нормативов по железу, мутности, цветности, что в значительной степени обусловлено высоким процентом изношенности водопроводных труб, наличием тупиковых участков [6]. Кроме того, организациями, осуществляющими эксплуатацию жилищно-коммунального хозяйства, как правило, не проводится контроль состояния питьевой воды, что не позволяет своевременно принять меры по замене внутридомовых инженерных сетей холодного водоснабжения.

3. Река Нева, являясь поверхностным источником водоснабжения, характеризуется слабой минерализацией воды. В невской воде отмечается крайний недостаток фтора, кальция, калия и ряда других элементов [6]. Указанное обстоятельство приводит к дефициту микронутриентов, необходимых для обеспечения нормальной жизнедеятельности организма, и, несомненно, способствует нарушению здоровья населения г. Санкт-Петербург [5]. Имеются многочисленные данные, показывающие, что дефицит йода в питьевой воде способствует развитию врождённых аномалий и снижению умственных способностей, недостаток фтора - заболеваемости детей кариесом, недостаток кальция и магния - увеличению тяжести течения кардио-васкулярных заболеваний [3-6]. Практически каждый житель г. Санкт-Петербург с большой степенью вероятности подвержен риску возникновения заболеваний, обусловленных использованием маломинерализованных питьевых вод, что приводит к заболеваниям костно-мышечной, сердечно-сосудистой, эндокринной систем. Таким образом, важнейшим профилактическим мероприятием в г. СанктПетербург является снабжение населения не только безопасной и безвредной, но и физиологически полноценной питьевой водой сбалансированного минерального состава.

В 2008 г. Управлением Роспотребнадзора по г. Санкт-Петербургу, ФГУЗ «Центр гигиены и эпидемиологии в г. Санкт-Петербург», ГУП «Водоканал Санкт-Петербурга», Санкт-Петербургской государственной медицинской академией им. И.И. Мечникова, ГУ «НИИ экологии человека и гигиены окружающей среды им. А.Н. Сысина» была разработана Концепция обеспечения населения физиологически полноценной питьевой водой, проведено ее полное гигиеническое обоснование, начата разработка технологических решений для производства физиологически полноценной питьевой воды $[5,6]$.

Федеральный закон Российской Федерации от 07.12.2011 г. № 416-Ф3 «О водоснабжении и водоотведении» ставит дополнительные задачи, связанные с обеспечением качества и безопасности воды, подаваемой с использованием систем горячего и холодного водоснабжения. Для реализации закона ГУП «Водоканал Санкт-Петербурга» совместно с Управлением разрабатываются и реализуются мероприятия, направленные на усиление барьерных функций городских водопроводных сооружений. Санкт-Петербург приступил к обновлению головных сооружений водоснабжения. В 2011-2012 гг. введен в строй блок дополнительной очистки с использованием предварительного озонирования воды производительностью 350 тыс. м²/сут на Южной водопроводной станции. В целом же для предоставления населению г. СанктПетербург гарантированно безопасной и безвредной питьевой водой, отвечающей требованиям законодательства в области обеспечения санитарно-эпидемиологического благополучия населения, по нашему мнению, необходимо:

- организоватть полный переход на более эффективные и технически совер- 
шенные двухступенные технологии водоподготовки питьевой воды на всех водопроводных станциях, одновременно развивая систему водоснабжения пригородных территорий;

- органам исполнительной власти субъектов Северо-Западного федерального округа, расположенным на водосборной терри- тории бассейна Ладожского озера, разработать программу, направленную на снижение загрязнения воды в Неве;

- для сохранения и укрепления здоровья горожан реализовать Концепцию обеспечения населения г. Санкт-Петербург физиологически-полноценной питьевой водой.

\section{Список литературы}

1. Гигиеническое обоснование эффективности водоподготовки в Санкт-Петербурге на основе метода интегральной оценки питьевой воды по показателям химической безвредности / А.В. Киселев, А.В. Мельцер, Н.В. Ерастова, А.А. Шульга // Современные проблемы военной медицины, обитаемости и профессионального отбора: материалы Всерос. науч.-практ. конф., 17-18 ноября 2011 г. - СПб.: ВМедА, 2011. - С. 128-129.

2. Гигиенические основы формирования перечней показателей для оценки и контроля безопасности питьевой воды / Г.Н. Красовский [и др.] // Гигиена и санитария. - 2010. - № 4. - С. 8-12.

3. Интегральная оценка питьевой воды по показателям химической безвредности на основе методологии оценки риска для здоровья населения, апробированная на водопроводных станциях ГУП «Водоканал Санкт-Петербурга» / А.В. Мельцер, А.В. Киселев, Н.В. Ерастова, А.А. Шульга // Гигиенические и медикопрофилактические технологии управления рисками здоровью населения: материалы 2-й Всерос. науч.практ. конф. с междунар. участием / под общ. ред. Г.Г. Онищенко, Н.В. Зайцевой. - Пермь: Книжный формат, 2011. - С. 158-161.

4. Онищенко Г.Г. О состоянии и мерах по обеспечению безопасности хозяйственно-питьевого водоснабжения населения Российской Федерации // Гигиена и санитария. - 2010. - № 3. - С. 4-5.

5. Бенчмаркинг качества питьевой воды / Г.Г. Онищенко, Ю.А. Рахманин, В.Ф. Кармазинов, В.А. Грачев, Е.Д. Нефедова. - СПб.: Новый журнал, 2010. - 432 с.

6. Обеспечение населения Санкт-Петербурга физиологически полноценной питьевой водой: миф или реальность / О.Е. Сергеев, И.А. Меркушев, И.М. Ахметзянов, Г.Г. Виноградова, Л.В. Воробьева, Е.А. Есина, Г.И. Золотова, А.В. Мельцер, И.Ю. Меркушева, И.А. Ракитин, П.Г. Ромашов, К.Б. Фридман; под ред. О.Е. Сергеева, И.А. Меркушева. - СПб.: Эдиция, 2011. - 169 с.

\section{References}

1. Kiselev A.V., Mel'tser A.V., Erastova N.V., Shul'ga A.A. Gigienicheskoe obosnovanie effektivnosti vodopodgotovki $\mathrm{V}$ Sankt-Peterburge na osnove metoda integral'noy otsenki pit'evoy vody po pokazatelyam khimicheskoy bezvrednosti [The hygienic justification of the effectiveness of water treatment in St. Petersburg based on an integrated assessment of drinking water according to chemical safety indicators]. Sovremennye problemy voennoy meditsiny, obitaemosti i professional'nogo otbora: materialy Vserossiyskoy nauchno-prakticheskoy konferentsii 17-18 noyabrya 2011 goda. St. Petersburg: VMedA, 2011, pp. 128-129.

2. Krasovskiy G.N. i dr. Gigienicheskie osnovy formirovaniya perechney pokazateley dlya otsenki i kontrolya bezopasnosti pit'evoy vody [Hygienic foundations for the development of lists of indicators for drinking water safety assessment and monitoring]. Gigiena i sanitariya, 2010, no. 4, pp. 8-12.

3. Mel'tser A.V., Kiselev A.V., Erastova N.V., Shul'ga A.A. Integral'naya otsenka pit'evoy vody po pokazatelyam khimicheskoy bezvrednosti na osnove metodologii otsenki riska dlya zdorov'ya naseleniya, aprobirovannaya na vodoprovodnykh stantsiyakh GUP «Vodokanal Sankt-Peterburga» [An integral assessment of drinking water according to chemical safety indicators based on the methodology for human health risk assessment, applied at the "Vodokanal of St. Petersburg" water supply stations]. Gigienicheskie i mediko-profilakticheskie tekhnologii upravleniya riskami zdorov'yu naseleniya: materialy 2-y Vserossiyskoy nauchno-prakticheskoy konferentsii s mezhdunarodnym uchastiem. G.G. Onishchenko, N.V. Zaytseva. Perm': Knizhnyy format, 2011, pp. 158-161.

4. Onishchenko G.G. O sostoyanii i merakh po obespecheniyu bezopasnosti khozyaystvenno-pit'evogo vodosnabzheniya naseleniya Rossiyskoy Federatsii [On the condition and measures of ensuring the security of drinking water supply in the Russian Federation]. Gigiena i sanitariya, 2010, no. 3, pp. 4-5.

5. Onishchenko G.G., Rakhmanin Yu.A., Karmazinov V.F., Grachev V.A., Nefedova E.D. Benchmarking kachestva pit'evoy vody [Benchmarking of drinking water quality]. St. Petersburg: Novyy zhurnal, 2010. 432 p.

6. Sergeev O.E., Merkushev I.A., Akhmetzyanov I.M., Vinogradova G.G., Vorob'eva L.V., Esina E.A., Zolotova G.I., Mel'tser A.V., Merkusheva I.Yu., Rakitin I.A., Romashov P.G., Fridman K.B. Obespechenie nase- 
leniya Sankt-Peterburga fiziologicheski polnotsennoy pit'evoy vodoy: mif ili real'nost' [Providing St. Petersburg citizens with physiologically functional drinking water: a myth or reality]. Ed. O.E. Sergeev, I.A. Merkushev. St. Petersburg: Editsiya, 2011. 169 p.

\section{THE HYGIENIC JUSTIFICATION OF PREVENTIVE MEASURES TO PROVIDE THE ST PETERSBURG POPULATION WITH HIGH QUALITY DRINKING WATER}

\section{N.V. Erastova, A.V. Meltser}

St.-Petersburg Department of the Federal Service on Customers Rights Protection and Human Well-Being Surveillance, Russian Federation, 19 Stremyannaya st., St.-Petersburg, 191025

The high quality of drinking water is the result of a complex solution of multiple issues. The major issues are the development and implementation of state-of-the-art water treatment technologies, the use of effective mechanisms for laboratory monitoring, social and environmental health monitoring, the application of an integral approach to drinking water quality assessment and making hygienically justified decisions in the fields of water supply and disposal.

Keywords: risk assessment, integral assessment of drinking water, chemical safety of drinking water.

Evrastova Natalya Vyacheslavovna - head of research and information Department (e-mail: Erastova_NV@ 78.rospotrebnadzor.ru, Tel.: 8 (812) 572-48-29).

Meltser Alexandr Vitalievich - Dsc (Med), deputy director of Department (e-mail: uprav@78.rospotrebnadzor.ru, тел.: 8 (812) 764-54-38). 
УДК 613.31-65.011.46

\title{
ИНТЕГРАЛЬНАЯ ОЦЕНКА РИСКА ЗДОРОВЬЮ ПРИ ИСПОЛЬЗОВАНИИ ПИТЬЕВОЙ ВОДЫ, ПРОИЗВОДИМОЙ ОПРЕСНИТЕЛЬНЫМ ЗАВОДОМ «КАСПИЙ»
}

\author{
У.И. Кенесариев, А.Т. Досмухаметов, М.К. Амрин, А.Е. Ержанова, \\ А.А. Баймухамедов \\ Казахский национальный медицинский университет им. С.Д. Асфендиярова, \\ Республика Казахстан, 050012, г. Алматы, ул. Толе би, 94
}

На примере питьевой воды, производимой опреснительным заводом «Каспий», приведены результаты прогностической интегральной оценки качества питьевой воды по показателям химической безвредности на основе метода беспороговой оценки риска для здоровья населения. На этапе идентификации опасности исходной воды (Каспийское море) из 19 проанализированных веществ определены 11 приоритетных загрязнителей. Не выявлены вещества, обладающие канцерогенными свойствами. Суммарный риск развития рефлекторно-ольфакторных реакций и неканцерогенных эффектов при употреблении населением питьевой воды, подаваемой в распределительную сеть, не превышал приемлемый уровень как для отдельных веществ, так и при их комбинированном действии. Дополнительных мер по регулированию качества воды не требовалось.

Ключевые слова: Казахстан, питьевая вода, беспороговые неканцерогенные риски.

Проблема снабжения населения, проживающего в условиях аридных и антропогенно загрязненных прибрежных морских зон, высококачественной питьевой водой остается крайне актуальной, в том числе и для Республики Казахстан. Одним из путей решения этой проблемы является использование различных технологий водоподготовки минерализованной воды Каспийского моря.

Так, в г. Актау уже функционируют дистилляционные опреснительные установки (ТОО «МАЭК-Казатомпром»), а в 2005 г. дополнительно был построен и введен в эксплуатацию опреснительный завод «Каспий», работающий на основе технологии обратного осмоса. Такая технология в условиях постоянно растущего потребления воды для данного региона является целесообразной как с экономической точки зрения, так и с позиций соблюдения прав потребителей на высококачественное питьевое водоснабжение.

Вместе с тем обеспечение населения высококачественной питьевой водой в условиях техногенного загрязнения воды Кас-

() Кенесариев У.И., Досмухаметов А.Т., Амрин М.К., Ержанова А.Е., Баймухамедов А.А., 2013

Кенесариев Усен Исмаилович - доктор медицинских наук, заведующий кафедрой общей гигиены и экологии, главный научный сотрудник лаборатории оценки рисков здоровью населения (e-mail: kenesary@inbox.ru, тел.: 8 (727) 29-26-722).

Досмухаметов Асхат Турсынханович - кандидат медицинских наук, доцент кафедры общей гигиены и экологии, ведущий научный сотрудник лаборатории оценки рисков здоровью населения (e-mail: zhantore@mail.ru, тел.: 8 (727) 29-26-722).

Амрин Мейрам Казиевич - кандидат медицинских наук, доцент кафедры общей гигиены и экологии, главный научный сотрудник лаборатории оценки рисков здоровью населения (e-mail: amrin_m@ mail.ru, тел.: 8 (727) 29-26-722)

Ержанова Ая Ералывна - кандидат медицинских наук, старший преподаватель кафедры общей гигиены и экологии, ведущий научный сотрудник лаборатории оценки рисков здоровью населения (e-mail: aya.er@mail.ru, тел.: 8 (727) 29-26-722).

Баймухамедов Арман Азаматович - кандидат медицинских наук, младший научный сотрудник лаборатории по оценке рисков здоровью населения (e-mail: st.luca@bk.ru, тел.: 8 (727) 29-26-722). 
пийского моря создает серьезные ограничения. Техногенное загрязнение воды Каспийского моря происходит в течение длительного периода и формируется в основном тремя путями: за счет впадающих в море речных стоков, содержащих токсические вещества, поступления загрязняющих веществ в процессе перевозки грузов (в основном нефти и нефтепродуктов) водным транспортом и в результате добычи нефти на морской акватории и в прибрежных зонах. В этой связи обостряется проблема использования данного объекта как источника водоснабжения населения прибрежных районов прикаспийского региона Республики Казахстан.

В условиях необходимости и целесообразности использования минерализованных загрязненных морских вод для задач водоснабжения населения особую значимость приобретает применение высокоэффективных технологий водоподготовки морской воды. При этом выбор технологических схем водоподготовки или их модернизаций должен быть ориентирован на результаты оценки рисков для здоровья населения при употреблении питьевой воды заданного качества.

В этой связи основной целью настоящей работы являлась оценка риска для здоровья населения при использовании питьевой воды, прошедшей специальную водоподготовку (на примере завода «Каспий»).

Материалы и методы исследования. Оценка рисков здоровью населения, потенциально связанных с употреблением питьевой воды, осуществлялась в соответствии с Руководством 2.1.10.1920-04 [6].

Для ранжирования веществ, не обладающих канцерогенным риском, применялись весовые коэффициенты $(T W)$, основанные на референтных дозах $(R f D)$ или концентрациях (RfC) (Руководство 2.1.10.1920-04). Определение индекса сравнительной неканцерогенной опасности $H R I$ осуществлялось по формуле

$$
H R I=E \cdot T W \cdot P / 10000,
$$

где $E$ - величина условной экспозиции (принимаются расчеты средней суточной дозы); $T W$ - весовой коэффициент влияния на здоровье; $P$ - численность популяции.
В связи с тем что популяция, которая находится под воздействием факторов, рассматривается в целом (г. Актау), при расчетах HRI и HRIc показатели P/ 10000 не учитывались.

Кроме этого, выполнена интегральная оценка питьевой воды по показателям химической безвредности в соответствии с MP 2.1.4.0032-11 [7]. Алгоритм оценки включал: 1) оценку риска появления ольфакторно-рефлекторных эффектов; 2) оценку неканцерогенных эффектов (беспороговая модель); 3) оценку интегрального риска (суммация эффектов). На каждом этапе значения рисков оценивались в сопоставлении с их приемлемыми уровнями. Расчеты параметров беспороговых моделей органолептических и неканцерогенных рисков выполнены по стандартным формулам [7] для условий различных температурных режимов $\left(1{ }^{\circ} \mathrm{C}, 15^{\circ} \mathrm{C}, 25^{\circ} \mathrm{C}\right)$, соответствующих сезонов года и содержания химических веществ в исходной воде. В связи с особенностями температурного режима Каспийского моря (относительно низкие значения) в качестве средней была принята величина $15{ }^{\circ} \mathrm{C}$, которая учтена как базовая в Техническом задании на проектную документацию данного объекта.

Все расчеты производились на прогнозную ситуацию, связанную с планируемым вводом завода «Каспий» в эксплуатацию. При оценке риска использовались величины референтных доз исследуемых веществ (12 соединений) или величины предела допустимых концентраций (ПДК) (7 соединений).

Оценка экспозиции проведена для условий перорального поступления, при этом использованы стандартные значения, рекомендованные ВО3 [6]: потребление воды 2 л/сут; частота воздействия - 365 дней, продолжительность воздействия - 30 лет; масса тела - 70 кг; период осреднения, число дней - в течение 30 лет по 365 дней. Максимальная дневная экспозиция принята равной 24 ч.

Оценка риска развития рефлекторноольфакторных эффектов выполнена только 
в отношении значимых показателей органолептических свойств воды, при этом значения риска приравнивались к нулю при низких значениях (Prob) показателей (хлор остаточный и связанный, хлориды). Оценка суммарного органолептического риска осуществлялась выбором максимального значения из всей группы величин, характерных для каждого из веществ [5].

Результаты и их обсуждение. Анализ проектной документации показал, что в технологии обработки морской воды (Каспийское море) используются фильтрационная очистка воды с коагуляцией и флокуляцией, обратноосмотическое опреснение и физикохимическая корректировка состава пресной воды. На водоподготовку направляется исходная вода с содержанием химических примесей и нефтепродуктов. Селективность мембран, ипользуемых заводом «Каспий», по показателям содержания нефтепродуктов высокая, эффективность очистки составляет 99,5\%, в том числе при высоких (порядка 3,0 мг/л) исходных уровнях.

На этапе идентификации опасности в исходной воде было учтено и проранжировано 19 химических соединений, из них 11 - отнесены к приоритетным, в том числе соединения, характерные для морских вод: хлориды, сульфаты и минеральные соединения, учитываемые показателем качества воды «сухой остаток». Установлено, что идентифицированные вещества при поступлении с питьевой водой в организм человека в дозах, превышающих референтные, могут создавать риск появления нарушений функций критических органов/систем: нервной системы, системы кровообращения, желудочно-кишечного тракта, почек, зубной и костной ткани, репродуктивной системы.

Веществ, обладающих канцерогенными свойствами, в исходной воде не обнаружено.

На этапе оценки экспозиции для условий перорального поступления идентифицированных соединений в организм с питьевой водой рассчитаны среднесуточные дозы (табл. 1).
Таблица 1

Значения ожидаемых среднесуточных доз (I) веществ, содержащихся в воде на выходе с участка кондиционирования, мг/(кг·день)

\begin{tabular}{|c|l|c|c|c|}
\hline $\begin{array}{c}\text { № } \\
\text { п/п }\end{array}$ & $\begin{array}{c}\text { Наимено- } \\
\text { вание } \\
\text { показателя }\end{array}$ & $\begin{array}{c}\text { Концентрация } \\
\text { веществ, } \\
\text { мг/л }\end{array}$ & $\begin{array}{c}\text { RfD, } \\
\text { мг·кг }\end{array}$ & $\begin{array}{c}I \text { (средне- } \\
\text { суточная } \\
\text { доза), мг·кг }\end{array}$ \\
\hline 1 & Натрий & 6,05 & 34,3 & 0,166 \\
\hline 2 & Кальций & 30 & 41,4 & 0,822 \\
\hline 3 & Магний & 0,67 & 11 & 0,018 \\
\hline 4 & Сульфаты & 38,75 & $-*$ & 1,062 \\
\hline 5 & Хлориды & 10,07 & $-*$ & 0,276 \\
\hline 6 & Фтор & 1,01 & 0,06 & 0,028 \\
\hline 7 & Бром & 0,14 & 1 & 0,004 \\
\hline 8 & Бор & 0,36 & 0,2 & 0,010 \\
\hline 9 & $\begin{array}{l}\text { Сухой } \\
\text { остаток }\end{array}$ & 133,14 & $-*$ & 3,648 \\
\hline 10 & $\begin{array}{l}\text { Гидрокарбо- } \\
\text { наты }\end{array}$ & 44,13 & $-*$ & 1,209 \\
\hline
\end{tabular}

Примечание. * Референтные дозы не установлены.

Наиболее высокие значения среднесуточных доз выявлены у сульфатов $(1,06)$, гидрокарбонатов $(1,209)$ и сухого остатка $(3,648)$, на которые не установлены референтные дозы. По остальным веществам (за исключением хлоридов) среднесуточные дозы были значительно ниже референтных уровней.

На этапе оценки риска развития рефлекторно-ольфакторных эффектов получены характеристики основных органолептических показателей качества воды и веществ, их формирующих (табл. 2).

Суммарная оценка органолептического риска от использования данной питьевой воды составила 0,001, при этом приоритетными факторами явились сухой остаток и водородный показатель.

Результаты оценки неканцерогенного риска для модельных условий водоподготовки на опреснительном заводе «Каспий» представлены в табл. 3.

Как видно из табл. 3, неканцерогенные беспороговые риски для отдельных рассматриваемых веществ не превышали прием- 
Таблица 2

Оценка риска развития рефлекторно-ольфакторных эффектов в питьевой воде

\begin{tabular}{|l|c|c|c|c|}
\hline \multicolumn{1}{|c|}{ Анализируемый критерий } & Значение & ПДК, мг/л & Prob & Риск \\
\hline Запах при $20^{\circ} \mathrm{C}$ & 0 & 2 & & 0 \\
\hline Привкус при $20^{\circ} \mathrm{C}$ & 0 & 2 & & 0 \\
\hline Цветность & 0 & 20 & $-3,33$ & 0 \\
\hline Мутность & 0 & 1,5 & -3 & 0,001 \\
\hline Водородный показатель & 7,9 & 9 & $-3,1$ & 0,0007 \\
\hline Общая жесткость & 3 & 7 & $-3,22168$ & 0 \\
\hline Хлориды & 41 & 350 & $-5,09186$ & 0,001 \\
\hline Сухой остаток & 228 & 500 & $-3,13224$ & 0 \\
\hline Хлор остаточный свободный & 0,08 & 0,5 & $-4,64232$ & 0 \\
\hline Хлор остаточный связанный & 0,06 & 1,2 & $-6,31942$ & 0,001 \\
\hline Суммарный риск рефлекторно-ольфакторных эффектов & & 0,1 \\
\hline Приемлемое значение рефлекторно-ольфакторных реакций \\
\hline
\end{tabular}

Пр и ме ч ан и е. * В данном случае значение Prob является промежуточной величиной для перехода от концентрации вредного вещества к риску для здоровья.

Таблица 3

Значения беспорогового неканцерогенного риска (Risk) веществ питьевой воды после обработки на опреснительном заводе перед поступлением в распределительную сеть

\begin{tabular}{|c|c|c|c|c|c|}
\hline \multirow{2}{*}{$\begin{array}{l}\text { Наименование } \\
\text { показателя }\end{array}$} & \multirow{2}{*}{ ПДК } & \multicolumn{2}{|c|}{$\begin{array}{c}\text { Вода после выхода } \\
\text { с фильтров-кондиционеров }\end{array}$} & \multicolumn{2}{|c|}{$\begin{array}{c}\text { Поток после выхода } \\
\text { из камерно-лучевого распределите- } \\
\text { ля }\end{array}$} \\
\hline & & $\begin{array}{c}\text { Концентрация ве- } \\
\text { ществ, мг/л }\end{array}$ & Risk & $\begin{array}{c}\text { Концентрация } \\
\text { веществ, мг/л }\end{array}$ & Risk \\
\hline Сульфаты & 500 & 69 & 0,0024 & 6,05 & 0,0005 \\
\hline Хлориды & 350 & 41 & 0,0020 & 30 & 0,0037 \\
\hline Фтор & 1,5 & 0,24 & 0,0028 & 0,67 & 0,0001 \\
\hline Сухой остаток & 1000 & 228 & 0,0040 & 38,75 & 0,0014 \\
\hline $\begin{array}{l}\text { Хлор остаточный } \\
\text { свободный }\end{array}$ & 0,5 & 0,08 & 0,0028 & 10,07 & 0,0005 \\
\hline $\begin{array}{l}\text { Хлор остаточный } \\
\text { связанный }\end{array}$ & 1,2 & 0,06 & 0,0009 & 1,01 & 0,0117 \\
\hline \multicolumn{3}{|c|}{ Приемлемый риск появления хронической интоксикации } & $\leq 0,02$ & & $\leq 0,02$ \\
\hline \multicolumn{3}{|c|}{ Суммарный неканцерогенный беспороговый риск } & 0,01476 & & 0,046 \\
\hline \multicolumn{3}{|c|}{$\begin{array}{l}\text { Приемлемая величина суммарного неканцерогенного бес- } \\
\text { порогового риска }\end{array}$} & $\leq 0,05$ & & $\leq 0,05$ \\
\hline
\end{tabular}

лемый уровень $(0,02)$. Суммарный неканцерогенный беспороговый риск от питьевой воды не превышал приемлемый уровень $(0,05)$ и составил 0,046 .

В целом неканцерогенные беспороговые риски для здоровья от качества питьевой воды, подаваемой в распределительную сеть, не превышали приемлемый уровень как для отдельных веществ, так и при комбинированном их действии.

Так как характеристика риска является заключительным этапом оценки риска и начальным этапом управления риском, нами была дана интегральная оценка риска (суммация эффектов) от качества питьевой воды, подаваемой в распределительную сеть.

Результаты расчета интегрального риска при оценке качества питьевой воды представлены в табл. 4.

Как видно из табл. 4 , отношение риска развития рефлекторно-ольфакторных эффектов к приемлемому значению составило 0,01, а отношение суммарного неканцерогенного риска к приемлемому уровню - 0,3. При этом интегральный показатель равен 0,31 , что не превышало нормативный уровень $(И П \leq 1)$. 
Таблица 4

Расчет интегрального показателя питьевой воды

\begin{tabular}{|l|c|c|c|}
\hline \multicolumn{1}{|c|}{ Вид риска } & $\begin{array}{c}\text { Значение } \\
\text { по суммарной оценке }\end{array}$ & $\begin{array}{c}\text { Величина } \\
\text { приемлемого значения }\end{array}$ & $\begin{array}{c}\text { Отношение риска } \\
\text { к приемлемому значению }\end{array}$ \\
\hline $\begin{array}{l}\text { Риск появления рефлекторно- } \\
\text { ольфакторных эффектов }\end{array}$ & 0,001 & 0,1 & 0,01 \\
\hline Неканцерогенный риск & 0,015 & 0,05 & 0,30 \\
\hline Канцерогенный риск & 0 & 0,00001 & 0,0 \\
\hline Интегральный показатель & & 0,31 \\
\hline
\end{tabular}

В целом риски по всем анализируемым показателям не превышали приемлемые уровни и не требовали принятия дополнительных мер по регулированию качества воды.

На этапе характеристики неопределенностей учтено, что неопределенности в оценке риска связаны с установлением референтных доз, релевантности, достоверности экстраполяции, приемлемости научных данных с учетом различных путей поступления исследуемых веществ в организм, особенностями проведения эпидемиологических исследований. Учет указанных неопределенностей на последующих этапах деятельности водоподготовки объекта позволит обеспечить минимизацию рисков, повысить объективность выводов и адекватность принимаемых управленческих решений.

Выводы. Впервые для условий Республики Казахстан осуществлены исследования по оценке риска на примере питьевой воды, производимой ТОО «Опреснительный завод “Каспий”». Исследования по оценке риска, выполненные по международно гармонизированной методологии в соответствии с принятыми в Российской Федерации нормативно-методическими до- кументами [7, 8], показали, что ведущими факторами неканцерогенного риска здоровью от употребляемой исходной воды могут являться 11 приоритетных соединений (в том числе хлориды, сульфаты, показатель сухого остатка и др., $H R I \geq 100)$. Веществ с канцерогенными свойствами в исходной воде не обнаружено.

Расчетные среднесуточные дозы для всех исследованных веществ, содержащихся в питьевой воде после очистки, были ниже референтных, что свидетельствует об отсутствии опасности для здоровья.

Суммарный риск оценен как приемлемый при хронической интоксикации отдельными веществами и при их комбинированном действии (интегральный показатель при суммации эффектов составил 0,31 , что не превышает регламент $(И П \leq 1))$. В связи, этим согласно правилам методологии анализа риска рекомендации по управленческим решениям не требуются.

В целом с учетом полученных данных производимая методом обратного осмоса опреснительным заводом «Каспий» питьевая вода по химическому составу не вызовет развития риска здоровью населения.

\section{Список литературы}

1. Разработка и апробация методики оценки риска здоровью населения от промышленных предприятий и автотранспорта на территории ЮВАО г. Москвы / С.Л. Авалиани, Н.Н. Филатов, О.И. Аксенова [и др.] // Окружающая среда. Оценка риска для здоровья. Опыт применения методологии оценки риска в Москве: сб. ЦГСЭН. РМАПО. - М., 1999. - С. 3-45.

2. Авалиани С.Л., Аксенова О.И., Пономарева О.В. Разработка и внедрение методологии оценки риска здоровью населения от воздействия загрязнения атмосферного воздуха и питьевой воды на территориях г. Москвы / Консультационный центр по оценке риска, ЦГСЭН в г. Москве. - М., 2000.

3. Авалиани С.Л., Ревич Б.М. Оценка риска загрязнения окружающей среды для здоровья населения как инструмент муниципальной экологической политики в Московской области. - М., 2010. - 311 с. 
4. Основы оценки риска для здоровья при воздействии химических веществ, загрязняющих окружающую среду / Г.Г. Онищенко, С.М. Новиков, Ю.А. Рахманин, С.Л. Авалиани, К.А. Буштуева. - М., 2002. $408 \mathrm{c.}$

5. Методические аспекты использования методологии оценки риска здоровью населения при воздействии факторов окружающей среды в Украине и России [Электронный ресурс] / М.Г. Щербань, В.В. Мясоедов, O.О. Шевченко, В.M. Савченко. - URL: http://www.nbuv.gov.ua/portal/natural/vkhnu/Med/2010_898/17.pdf (дата обращения: 27.12.2012).

6. Р 2.1.10.1920-04. Руководство по оценке риска для здоровья населения при воздействии химических веществ, загрязняющих окружающую среду: утв. Главным государственным санитарным врачом РФ 05.03.2004 [Электронный ресурс]. - URL: http://www.bestpravo.ru/rossijskoje/lq-zakony/j7b.htm (дата обращения: 10.07.2011).

7. МР 2.1.4.0032-11. 2.1.4. Питьевая вода и водоснабжение населенных мест. Интегральная оценка питьевой воды централизованных систем водоснабжения по показателям химической безвредности: методические рекомендации: утв. главным государственным санитарным врачом РФ 31.07.2011 [Электронный pecypc]. - URL: http://www.garant.ru/products/ipo/prime/doc/12090808/ (дата обращения: 31.07.2011).

8. Руководство по контролю качества питьевой воды: рекомендации. - Женева: Всемирная организация здравоохранения, 1986. - Т. 1, 2.

9. U.S. Environment Protection Agency [Электронный ресурc]. - URL:http://www.epa.gov/html/emci/chemref/ 60297/60297. html (дата обращения: 31.07.2011).

10. Интегральная оценка питьевой воды по показателям химической безвредности на основе методологии оценки риска для здоровья населения, апробированная на водопроводных станциях ГУП «Водоканал Санкт-Петербурга» / А.В. Мельцер, А.В. Киселев, Н.В. Ерастова, А.А. Шульга // Материалы 2-й Всерос. науч.-практ. конф. с междунар. участием «Гигиенические и медико-профилактические технологии управления рисками здоровью населения». - Пермь, 2011. - С. 574-158.

\section{References}

1. Avaliani S.L., Filatov N.N, Aksenova O.I. Razrabotka i aprobatsiya metodiki otsenki riska zdorov'yu naseleniya ot promyshlennykh predpriyatiy i avtotransporta na territorii YuVAO g. Moskvy [The development and validation of a methodology for assessing human health risks from industrial companies and motor vehicles in the Moscow South-Eastern Administrative Okrug]. Okruzhayushchaya sreda. Otsenka riska dlya zdorov'ya. Opyt primeneniya metodologii otsenki riska v Moskve. Moscow: TsGSEN. RMAPO, 1999. pp. 3-45.

2. Avaliani S.L., Aksenova O.I., Ponomareva O.V. Razrabotka i vnedrenie metodologii otsenki riska zdorov'yu naseleniya ot vozdeystviya zagryazneniya atmosfernogo vozdukha i pit'evoy vody na territoriyakh g. Moskvy [The development and implementation of a methodology for assessing human health risks from exposure to ambient air and drinking water pollution in Moscow]. Moscow: Konsul'tatsionnyy tsentr po otsenke riska, TsGSEN v g. Moskve, 2000.

3. Avaliani S.L., Revich B.M. Otsenka riska zagryazneniya okruzhayushchey sredy dlya zdorov'ya naseleniya kak instrument munitsipal'noy ekologicheskoy politiki v Moskovskoy oblasti [Human health risk assessment of environmental pollution on as a tool of municipal environmental policy in the Moscow Region]. Moscow, 2010. 311 p.

4. Onishchenko G.G., Novikov S.M., Rakhmanin Yu.A., Avaliani S.L., Bushtueva K.A. Osnovy otsenki riska dlya zdorov'ya pri vozdeystvii khimicheskikh veshchestv, zagryaznyayushchikh okruzhayushchuyu sredu [The foundations of human health risk assessment of exposure to environmental pollutants]. Moscow, 2002. 408 p.

5. Shcherban' M.G., Myasoedov V.V., Shevchenko O.O., Savchenko V.M. Metodicheskie aspekty ispol'zovaniya metodologii otsenki riska zdorov'yu naseleniya pri vozdeystvii faktorov okruzhayushchey sredy v Ukraine i Rossii [Methodological aspects of the use of a methodology for health risk assessment of exposure to environmental factors in Ukraine and Russia]. Available at: http://www.nbuv.gov.ua/portal/natural/vkhnu/Med/2010_898/17.pdf.

6. R 2.1.10.1920-04. Rukovodstvo po otsenke riska dlya zdorov'ya naseleniya pri vozdeystvii khimicheskikh veshchestv, zagryaznyayushchikh okruzhayushchuyu sredu [R 2.1.10.1920-04. Guidelines for human health risk assessment of exposure to environmental chemical pollutants]. Utv. Glavnym gosudarstvennym sanitarnym vrachom RF 05.03.2004. Available at: http://www.bestpravo.ru/rossijskoje/lq-zakony/j7b.htm.

7. MR 2.1.4.0032-11. 2.1.4. Pit'evaya voda i vodosnabzhenie naselennykh mest. Integral'naya otsenka pit'evoy vody tsentralizovannykh sistem vodosnabzheniya po pokazatelyam khimicheskoy bezvrednosti. Metodicheskie rekomendatsii [MR 2.1.4.0032-11. 2.1.4. Drinking water and water supply of residential areas. An integral assessment of centralized drinking water supply systems based on chemical safety indicators. Methodical guidelines]. Utv. Glavnym gosudarstvennym sanitarnym vrachom RF 31.07.2011. Available at: http://www.garant.ru/products/ipo/prime/doc/12090808/.

8. Rukovodstvo po kontrolyu kachestva pit'evoy vody: rekomendatsii [Guidelines for drinking water quality monitoring. Recommendations]. Zheneva: World Health Organization, 1986, vol. 1, 2.

9. U.S. Environment Protection Agency. Available at: http://www.epa.gov/html/emci/chemref/60297/60297. 
10.Mel'tser A.V., Kiselev A.V., Erastova N.V., Shul'ga A.A. Integral'naya otsenka pit'evoy vody po pokazatelyam khimicheskoy bezvrednosti na osnove metodologii otsenki riska dlya zdorov'ya naseleniya, aprobirovannaya na vodoprovodnykh stantsiyakh GUP «Vodokanal Sankt-Peterburga» [An integral assessment of drinking water according to chemical safety indicators based on the methodology for human health risk assessment, applied at the "Vodokanal of St. Petersburg" water supply stations]. Materialy 2-y Vserossiyskoy nauchno-prakticheskoy konferentsii s mezhdunarodnym uchastiem «Gigienicheskie i mediko-profilakticheskie tekhnologii upravleniya riskami zdorov'yu naseleniya». Perm', 2011, pp. 574-158.

\title{
ASSESSMENT OF INTEGRATED HEALTH RISK WHILE USING DRINKING WATER PRODUCED BY DESALINATION PLANT "CASPIAN"
}

\author{
U.I. Kenessaryiev, A.T. Dosmukhametov, M.K. Amrin, A.E. Yerzhanova, \\ A.A. Baimukhamedov \\ Kazakh National Medical University named after S.D. Asfendiyarov, Kazakhstan, \\ 94 Tole Bi st, Almaty, 050012
}

The article on the example of drinking water produced by desalination plants «Caspian» reviewed the results of predictive integrated assessment of drinking water quality in terms of chemical safety on the basis of nothreshold risk assessment for human health.

At the stage of hazard identification of 19 substances analyzed raw water (Caspian Sea) identified 11 priority pollutants. There were not identified chemicals with carcinogenic properties. Overall risk of reflex responses of olfactory and non-carcinogenic health effects on the quality of drinking water supplied to the distribution system does not exceed the acceptable level, for individual substances and the combined action. Additional measures to regulate the quality of water is not required.

Keywords: Kazakhstan; drinking water; non-threshold non-carcinogenic risk.

(C) Kenessaryiev U.I., Dosmukhametov A.T., Amrin M.K., Yerzhanova A.E., Baimukhamedov A.A., 2013

Kenesariev Usen Ismagilivich - D. Sc (Med), Head of Department of common hygiene and ecology, leader research fellow of public health risk assessment laboratory (e-mail: kenesary @inbox.ru, tel.: 8 (727) 29-26-722)

Dosmuhametov Ashat Tursynhanovich - PhD, docent of Department of common hygiene and ecology, leader research fellow of public health risk assessment laboratory (e-mail: zhantore@ mail.ru, tel.: 8 (727) 29-26-722).

Amrin Meyram Kazievich - PhD, docent of Department of common hygiene and ecology, leader research fellow of public health risk assessment laboratory (e-mail: amrin_m@mail.ru, tel.: 8 (727) 29-26-722).

Erzhanova Aya Eralyvna - PhD, head teacher of Department of common hygiene and ecology, leader research fellow of public health risk assessment laboratory (e-mail: aya.er@mail.ru, tel.: 8 (727) 29-26-722).

Bajmuhamedov Arman Azamatovich - PhD, research fellow of public health risk assessment laboratory (e-mail: st.luca@bk.ru, tel.: 8 (727) 29-26-722). 


\title{
ЭКСПЕРИМЕНТАЛЬНЫЕ МОДЕЛИ И ИНСТРУМЕНТАЛЬНЫЕ ИССЛЕДОВАНИЯ
}

УДК 615.9, 614.7

\section{ТОКСИКОЛОГО-ГИГИЕНИЧЕСКАЯ ОЦЕНКА БЕЗОПАСНОСТИ ВОДНОЙ СУСПЕНЗИИ НАНОДИСПЕРСНОГО ДИОКСИДА КРЕМНИЯ, СИНТЕЗИРОВАННОГО МЕТОДОМ ЖИДКОКРИСТАЛЛИЧЕСКОГО ТЕМПЛАТИРОВАНИЯ}

\author{
Н.В. Зайцева', М.А. Землянова', В.Н. Звездин ${ }^{1}$, Е.В. Саенко² \\ 1 Федеральный научный центр медико-профилактических технологий управления \\ рисками здоровью населения, Россия, 614045, г. Пермь, ул. Монастырская, 82 , \\ 2 Институт технической химии Уральского отделения РАН, Россия, 614013, г. Пермь, \\ ул. Академика Королёва, 3
}

В результате экспериментального исследования водной суспензии нанодисперсного диоксида кремния, синтезированного методом темплатирования, при однократном внутрижелудочном зондовом введении установлен 3-й класс опасности тестируемого продукта по критерию ЛД фологических изменений в наименьшей исследованной дозе 500 мг/кг в виде выраженных изменений системы кровообращения, проявляющихся значительным расширением и полнокровием крупных венозных сосудов печени, почек, тимуса. Обнаружены активация пролиферативных процессов в лимфоидной и макрофагальной системах, развитие дегенеративных изменений в печени, почках, красной пульпе селезёнки, легких.

При введении микродисперсного аналога таким же способом гибели экспериментальных животных не установлено (4-й класс опасности). В дозе 500 мг/кг выявлен комплекс морфологических изменений в виде умеренных сосудистых модификаций в почках, сердце, головном мозге, в печени; незначительных пролиферативных изменений в печени, пролиферативная реакция лимфоидной ткани, лимфоидная инфильтрация в ткани пищевода, желудка, печени, почках, в толстой кишке.

Ключевые слова: водная суспензия нанодисперсного диоксида кремния, потенциальная опасность, токсиколого-гигиеническая оценка, здоровье населения.

В соответствии с мировыми тенденциями развития рынка высоких технологий формирование национальной наноиндустрии, обозначенное Программой развития наноиндустрии в Российской Федерации до 2015 г., как важнейшее приоритетное стратегическое направление определяет новые подходы к преобразованию оте- чественной промышленности. Рынок нанопродукции в России к 2016 г. должен вырасти более чем в 10 раз по сравнению с 2011 г. - до 900 млрд рублей, что повысит конкурентоспособность отечественной продукции [1].

Интенсивное формирование нанокластеров за рубежом и в Российской Федера-

(C) Зайцева Н.В., Землянова М.А., Звездин В.Н., Саенко Е.В., 2013

Зайцева Нина Владимировна - академик РАМН, доктор медицинских наук, профессор; директор (е-таil: znv@fcrisk.ru, root@fcrisk.ru, тел.: 8 (342) 237-25-34)

Землянова Марина Александровна - доктор медицинских наук, профессор, заведующий отделом биохимических и цитогенетических методов диагностики (e-mail: zem@fcrisk.ru, тел.: 8 (342) 236-39-30).

Звездин Василий Николаевич - научный сотрудник отдела биохимических и цитогенетических методов диагностики (e-mail: zvezdin@fcrisk.ru, тел.: 8 (342) 237-18-15).

Саенко Екатерина Владимировна - кандидат химических наук; научный сотрудник лаборатории многофазных дисперсных систем (e-mail: saenko_ekaterina@ mail.ru, тел.: 8 (342) 237-82-80). 
ции, развитие сегментов мирового рынка нанопродуктов в разрезе группы «Наноматериалы», рост коммерческих применений в ключевых отраслях - в медицине, биотехнологиях, энергетике, электронике и информационных технологиях, обрабатывающей промышленности, в потребительском сектоpe [2] - диктуют необходимость системного развития работ по изучению потенциальных угроз в сфере жизнедеятельности человека, связанных с широкомасштабным развитием и распространением нанотехнологий и нанобиотехнологий.

На сегодняшний день для научного мирового сообщества проблемы нанотоксикологии и биобезопасности используемых наноматериалов выходят на одно из первых мест по значимости и, соответственно, по числу работ в этой области. В рамках исследования взаимодействия наноструктур с биологическими системами особое внимание уделяется выявлению связи между физическими и химическими свойствами наноматериалов (такими как размер, форма, структура поверхности, состав и степень агрегации, растворимость) с индукцией токсического ответа в биологических структурах [3-6]. Данное направление развивается в ФБУН «Федеральный научный центр медико-профилактических технологий управления рисками здоровью населения», в рамках которого выполняется токсиколого-гигиеническая оценка безопасности синтезируемых наноматериалов [7].

В перечень синтезируемых наноматериалов входят аморфные мезопористые нанодисперсные частицы диоксида кремния. В перспективе высока вероятность их использования в качестве активной субстанции, осуществляющей адресную доставку в организме человека лекарственных препаратов нового поколения [8]. Ожидаемые объемы получения и использования данного продукта могут составлять до 1000 т в год, что оценивается как массово выпускаемый продукт [9]. При этом возможно прямое экспонирование персонала, участвующего в процессе производства (ингаляционное поступление), и населения, являю- щегося потребителями данной продукции (пероральное применение лекарственных форм). Также возможно использование мезопористых нанодисперсных частиц диоксида кремния в качестве биосенсоров, контрастирующих агентов для магнитно-резонансной томографии в медицине [10]. Ожидаемый объем получения и использования в этих целях данного продукта может составлять до $1 \mathrm{~T}$ в год, экспонируемая категория населения персонал в лабораторных масштабах.

Предварительная оценка потенциальной опасности нанодисперсного диоксида кремния для здоровья человека, выполненная на основании аналитического обобщения комплекса физико-химических, молекулярно-биологических, биохимических, цитологических, экологических характеристик по результатам собственных исследований и данных аннотируемой литературы, свидетельствует о средней степени опасности по критерию «частной» опасности $(D)$. Значение $D$ составило 1,75 , что соответствует диапазону 1,111-1,779, оцениваемому как «средняя степень потенциальной опасности» [9], и требует дальнейших токсиколого-гигиенических исследований.

Цель настоящей работы - экспериментальное исследование и оценка токсичности и морфологических особенностей тканей внутренних органов и систем при воздействии нанодисперсного диоксида кремния, синтезированного методом жидкокристаллического темплатирования.

Материалы и методы. В экспериментальных исследованиях изучена водная суспензия нанодисперсного диоксида кремния $\left(\mathrm{SiO}_{2} \times 0,14 \mathrm{H}_{2} \mathrm{O}\right)$, полученная стандартным способом синтеза наноструктур - методом жидкокристаллического темплатирования с использованием в качестве структурообразующего агента (темплата) поверхностноактивного вещества (ПАВ) - цетилтриметиламмония бромида $\left(\mathrm{C}_{16} \mathrm{H}_{33}\left(\mathrm{CH}_{3}\right)_{3} \mathrm{NBr}\right.$, ЦТАБ) $[11,12]$. Синтез осуществлен в лаборатории многофазных дисперсных систем Института технической химии Уральского отделения РАН. Использование мицелл поверхностноактивного вещества предотвращало рост 
частиц и позволило синтезировать стабилизированные частицы определенных размеров, коррелирующих с размерами мицелл [13]. ЦТАБ удаляли многократной экстракцией этанолом в подкисленной среде (с помощью соляной кислоты), степень экстракции составила не менее $98 \%$. Остаточную концентрацию ЦТАБ в нанодисперсном растворе диоксида кремния определяли на жидкокристаллическом хроматографе с тандемным масс-спектрометрическим детектором Agilent 6460 (США). Для сравнительного анализа параметров токсичности и морфологических особенностей тканей внутренних органов и систем в остром эксперименте синтезирован водный микродисперсный раствор диоксида кремния $\left(\mathrm{SiO}_{2} \times 0,08 \mathrm{H}_{2} \mathrm{O}\right)$ по методу Штобера [14].

Оценку размера и формы нано- и микродисперсных частиц вещества в водной суспензии выполняли методом динамического светорассеяния на анализаторе Horiba LB-550 (Horiba, Япония) и на лазерном анализаторе Microtrac S3500 (Microtrac, CШA). Удельную площадь поверхности $\left(S_{\mathrm{BET}}\right)$ частиц определяли методом Брунауэра, Эммета и Тейлора [15], текстурные параметры сорбцией азота при температуре $-196^{\circ} \mathrm{C}$ на анализаторе ASAP 2020 (Micromeritics, США). Распределение пор по размерам осуществляли по изотермам десорбции по методу Баррета, Джойнера и Халенды [16]. Концентрацию кремния в водной суспензии определяли методом атомно-адсорбционной спектрометрии с ацетилено-воздушным пламенем на анализаторе Perkin Elmer 3110 (Perkin Elmer Inc., США).

Оценку токсичности и морфологических особенностей тканей внутренних органов и систем в остром эксперименте при введении тестируемых веществ проводили на материале половозрелых мышей линии

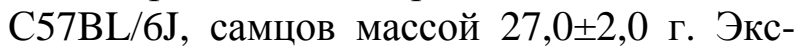
периментальные животные были разделены на 10 групп по 10 мышей в каждой. Водную суспензию нанодисперсного диоксида крем-

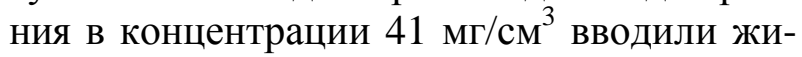
вотным 1, 2, 3-й опытных групп однократно зондово внутрижелудочно в дозе 500, 1000,
1500 мг/кг в объеме 0,3, 0,6, 0,9 мл соответственно. Животным 1, 2, 3-й групп сравнения вводили микродисперсный водный рас-

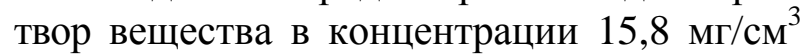
в аналогичных дозах и тем же способом в объеме 0,8, 1,6, 2,4 мл. Животным 4, 5, 6-й групп сравнения аналогичным способом вводили водный раствор, содержащий ЦТАВ в концентрации $0,96 \mathrm{Mг} / \mathrm{cm}^{3}$, что в 10 раз превышает остаточную концентрацию вещества в водной суспензии нанодисперсного диоксида кремния, в объеме 0,3, 0,6, 0,9 мл (в дозах 1,15, 2,30, 3,46 мг/кг). Контрольной группе вводили дистиллированную воду в объеме, эквивалентном объему введенной суспензии экспериментальным животным опытных групп. Критериями токсического действия соединений служили: летальный эффект, среднее время гибели животных, клиническая картина развития интоксикации. Срок наблюдения составил 14 дней.

Животные на протяжении всего эксперимента содержались в условиях лабораторного вивария (по 5 особей в полипропиленовых клетках стандартного размера T/3) на полусинтетическом рационе согласно методическим указаниям «Токсиколого-гигиеническая оценка безопасности наноматериалов» (МУ 1.2.2520-09). Доступ к корму и питью не ограничивали. Температура в помещениях в период наблюдения составляла $23,0 \pm 2,0{ }^{\circ} \mathrm{C}$, влажность воздуха $60,0 \pm 5,0 \%$. Экспериментальные манипуляции производили в соответствии с требованиями «Правил проведения работ с использованием экспериментальных животных». Выживших животных выводили из эксперимента методом декапитации.

У животных, погибших во время эксперимента и выведенных из опыта после его завершения, забирали последовательно печень, селезёнку, почки, сердце, пищевод, тонкий и толстый кишечник, легкие, семенники, тимус, паховые лимфоузлы, полушария головного мозга, мозжечок. Органы фиксировали в 10\%-ном растворе нейтрального формалина, затем заливали в парафин. Для подготовки микропрепаратов серийные срезы окрашивали гематоксилином 


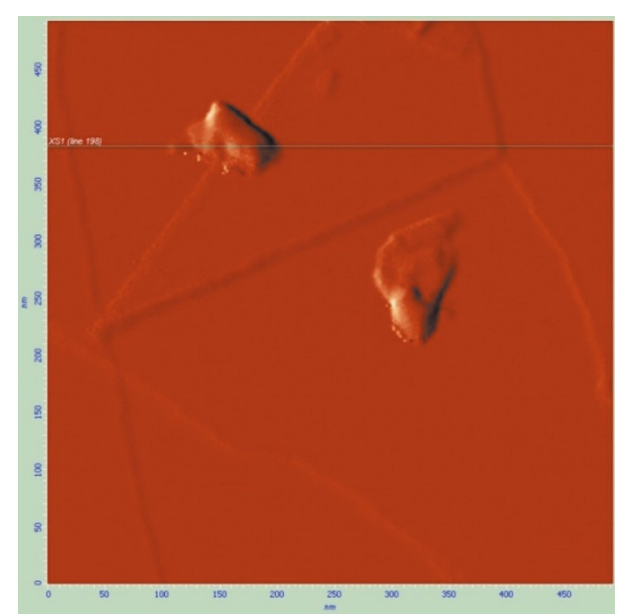

Рис. 1. Изображение синтезированных частиц нанодисперсного диоксида кремния с помощью атомно-силовой микроскопии

и эозином, метиловым зелёным и пиронином по Браше с контрольной обработкой РНКазой, шифф-йодной кислотой с контролем амилазой на гликоген и нейтральные гликозаминогликаны (ГАГ), альциановым синим для выявления кислых ГАГ. Визуализацию микропрепаратов осуществляли на световом микроскопе Micros (Micros, Австрия) при увеличении $100-1000^{\mathrm{x}}$.

Результаты и их обсуждение. $67 \%$ диспергированных частиц водной суспензии, исследованной в эксперименте, имели эллипсовидную форму с размером меньшей осей 25-35 нм, 33 \% частиц имели сферическую форму диаметром 25 нм (рис. 1, 2). Микрочастицы диоксида кремния являлись частицами «традиционной» дисперсности (1 мкм и более), в меньшей из осей имели размер 3,9 мкм.

Удельная площадь поверхности наночастиц составила $96,96 \mathrm{~m}^{2} / \Gamma$, что соответствует удельной площади поверхности частиц наноразмерного диапазона (от 50 до $380 \mathrm{~m}^{2}$ на 1 г вещества) и превышает в 7,6 раза удельную площадь поверхности микроразмерного аналога $\left(12,54 \mathrm{~m}^{2} / \Gamma\right)$.

Острая токсичность (ЛД 50 ) наноразмерного диоксида кремния в дисперсном растворе при однократном пероральном зондовом введении составила 4638 мг/кг, что соответствует 3-му классу опасности. Клиническая картина эффектов острой интоксикации характеризовалась в первые 20 мин

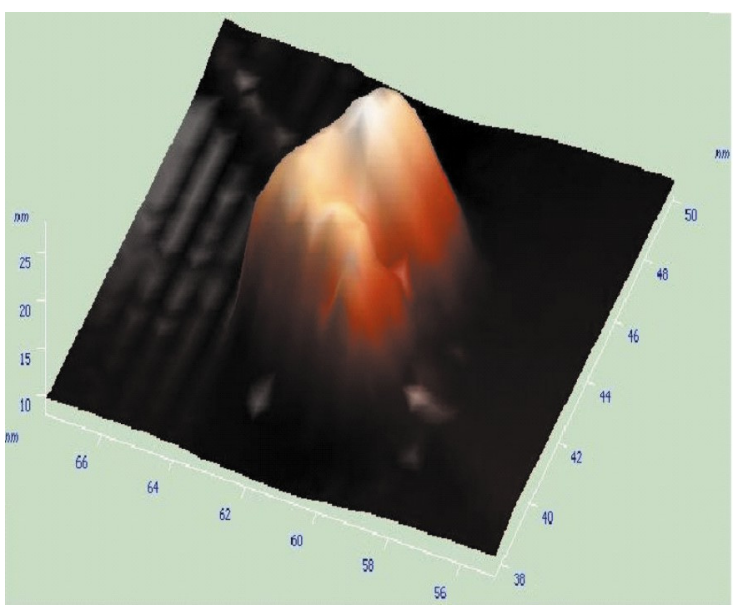

Рис. 2. 3D-конфигурация поверхности синтезированных частиц нанодисперсного диоксида кремния

эксперимента снижением двигательной активности, слабой реакцией на звуковые раздражители. На 2-3-и сутки отмечалось значительное вздутие брюшной полости, поверхностное дыхание, ограничение подвижности. Преимущественная гибель экспериментальных животных зафиксирована на 2-4-е сутки (таблица). Гибели животных с исследованным диапазоном доз для водной суспензии микродисперсного диоксида кремния и раствора ЦТАБ за период наблюдения не установлено (4-й класс опасности).

Установлено, что наночастицы водной суспензии диоксида кремния в дозах 1000 и 1500 мг/кг обладают токсическим действием на форменные элементы крови экспериментальных животных, характеризующимся наличием полихроматофильных эритроцитов (до $25 \%$ от общего числа эритроцитов крови), патологических телец Жоли в эритроцитах крови (до $10 \%$ от общего числа эритроцитов крови), выраженной агрегации тромбоцитов в крови. При введении микродисперсного диоксида кремния в аналогичных дозах негативных эффектов в отношении форменных элементов крови не установлено.

Установлено, что наночастицы водной суспензии диоксида кремния в дозах 1000 и 1500 мг/кг обладают токсическим действием на форменные элементы крови экспериментальных животных, характеризующимся наличием полихроматофильных эритроцитов 
Динамика гибели экспериментальных животных после однократного зондового внутрижелудочного введения нано- и микродисперсной водной суспензии диоксида кремния и раствора ЦТАБ

\begin{tabular}{|c|c|c|c|c|c|c|c|c|c|c|}
\hline \multirow{2}{*}{$\begin{array}{l}\text { № } \\
\Pi / \Pi\end{array}$} & \multirow{2}{*}{$\begin{array}{c}\text { Экспериментальная } \\
\text { группа }\end{array}$} & \multirow{2}{*}{$\begin{array}{l}\text { Доза, } \\
\text { мг/кг }\end{array}$} & \multirow{2}{*}{$\begin{array}{c}\text { Число } \\
\text { животных } \\
\text { в группе }\end{array}$} & \multicolumn{5}{|c|}{ Сроки наблюдения, сут } & \multirow{2}{*}{$\begin{array}{c}\text { Число } \\
\text { погибших } \\
\text { животных }\end{array}$} & \multirow{2}{*}{ \% гибели } \\
\hline & & & & $1-\mathrm{e}$ & $2-e$ & $3-e$ & 4-e & $14-\mathrm{e}$ & & \\
\hline 1 & Опытная & 500,0 & 10 & $0 / 10$ & $0 / 10$ & $0 / 10$ & $1 / 10$ & $0 / 10$ & 1 & 10 \\
\hline 2 & Опытная & 1000,0 & 10 & $0 / 10$ & $0 / 10$ & $0 / 10$ & $4 / 10$ & $0 / 10$ & 4 & 40 \\
\hline 3 & Опытная & 1500,0 & 10 & $0 / 10$ & $0 / 10$ & $2 / 10$ & $2 / 10$ & $2 / 10$ & 2 & 20 \\
\hline 4 & Сравнения & 500,0 & 10 & $0 / 10$ & $0 / 10$ & $0 / 10$ & $0 / 10$ & $0 / 10$ & 0 & 0 \\
\hline 5 & Сравнения & 1000,0 & 10 & $0 / 10$ & $0 / 10$ & $0 / 10$ & $0 / 10$ & $0 / 10$ & 0 & 0 \\
\hline 6 & Сравнения & 1500,0 & 10 & $0 / 10$ & $0 / 10$ & $0 / 10$ & $0 / 10$ & $0 / 10$ & 0 & 0 \\
\hline 7 & Сравнения & 1,15 & 10 & $0 / 10$ & $0 / 10$ & $0 / 10$ & $0 / 10$ & $0 / 10$ & 0 & 0 \\
\hline 8 & Сравнения & 2,30 & 10 & $0 / 10$ & $0 / 10$ & $0 / 10$ & $0 / 10$ & $0 / 10$ & 0 & 0 \\
\hline 9 & Сравнения & 3,46 & 10 & $0 / 10$ & $0 / 10$ & $0 / 10$ & $0 / 10$ & $0 / 10$ & 0 & 0 \\
\hline 10 & Контрольная & - & 10 & $0 / 10$ & $0 / 10$ & $0 / 10$ & $0 / 10$ & $0 / 10$ & 0 & 0 \\
\hline
\end{tabular}

(до $25 \%$ от общего числа эритроцитов крови), патологических телец Жоли в эритроцитах крови (до $10 \%$ от общего числа эритроцитов крови), выраженной агрегации тромбоцитов в крови. При введении микродисперсного диоксида кремния в аналогичных дозах негативных эффектов в отношении форменных элементов крови не установлено.

Анализ морфологических изменений тканей внутренних органов при однократном внутрижелудочном введении водной суспензии нанодисперсного диоксида кремния в наименьшей из исследованных доз (500 мг/кг) показал наличие выраженных изменений системы кровообращения, проявляющихся резким расширением и полнокровием крупных венозных сосудов печени, почек, тимуса, мягкой мозговой оболочки, сердечной мышцы; резким расширением сосудов слизистой оболочки и подслизистой основы пищевода и желудка (рис. 3, $a, 4, a$ ).

Установлены активные пролиферативные процессы в лимфоидной и макрофагальной системах, характеризующиеся множественной мелкоочаговой, реже среднеочаговой лимфогистиоцитарной инфильтрацией в печени с перипортальными среднеочаговыми инфильтратами; немногочисленными мелкими диффузными межканальцевыми инфильтратами в почках, выраженной реакцией мезангиальных клеток и умеренным расширением просветов капсул Шумлянского-Боумена почечных телец; заполнением

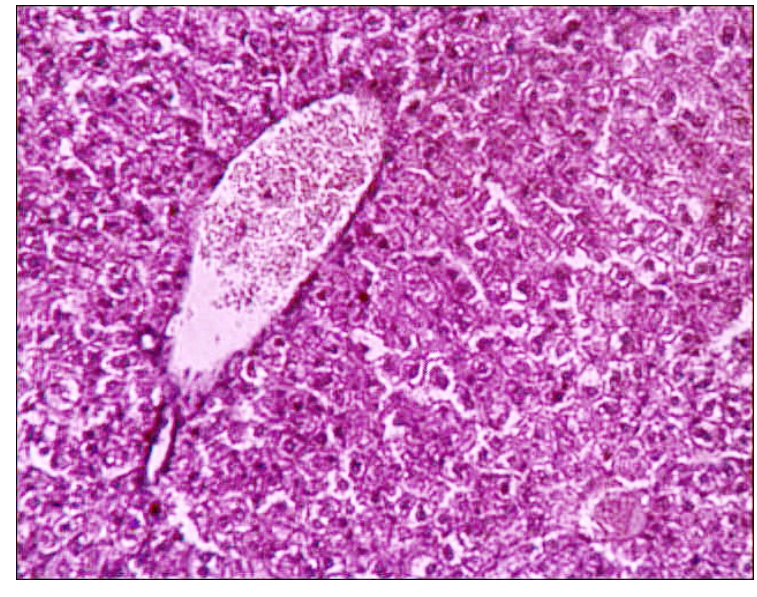

$a$

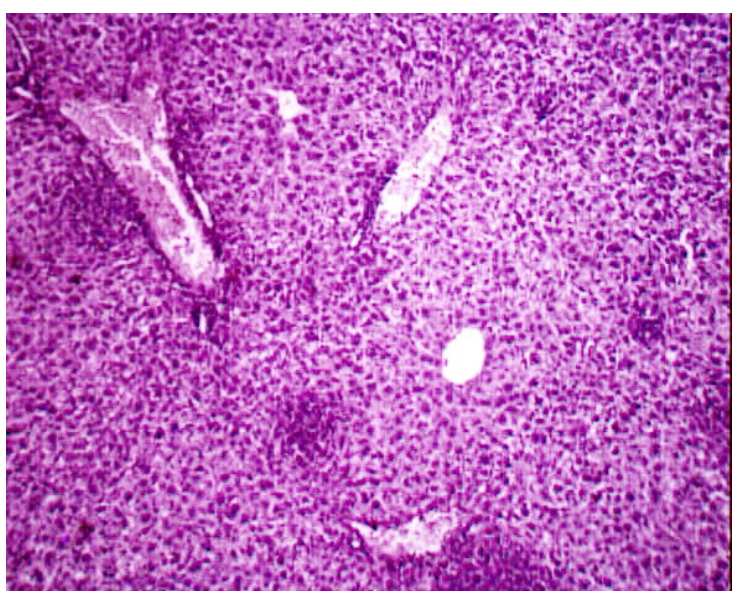

6

Рис. 3. Печень выжившей мыши при однократном зондовом внутрижелудочном введении водной суспензии: $a$ - нанодисперсного диоксида кремния в дозе 500 мг/кг (ув. $\times 200)$; $\sigma$ - микродисперсного диоксида кремния в дозе 500 мг/кг (ув. $\times 200)$ 


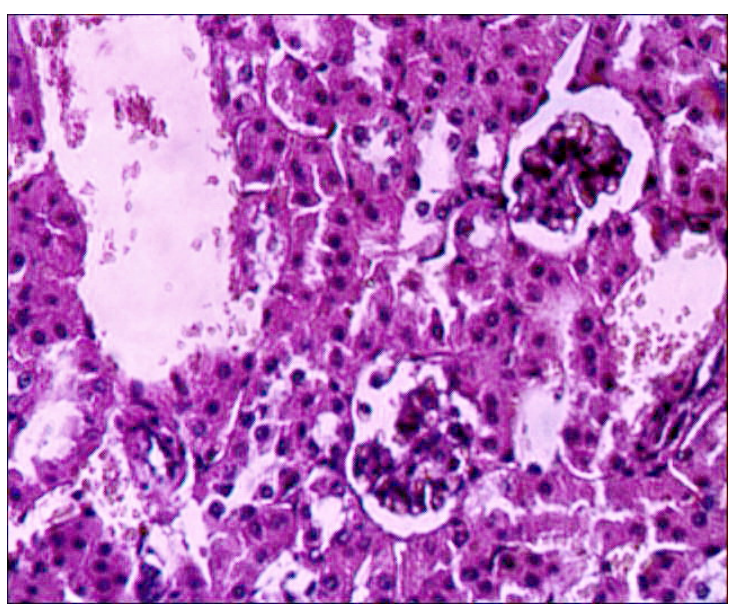

$a$

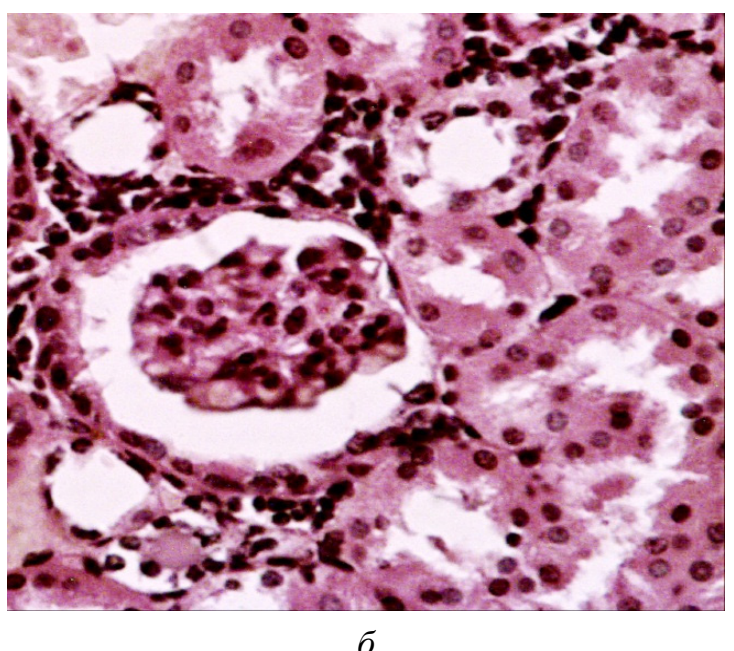

Рис. 4. Почка выжившей мыши (ув. ×400) при однократном зондовом внутрижелудочном введении водной суспензии нанодисперсного диоксида кремния в дозе 500 мг/кг (a) и микродисперсного диоксида кремния в дозе 500 мг/кг (б)

лимфоидными клетками красной пульпы селезёнки, сливным характером лимфатических узелков белой пульпы селезенки; практическим отсутствием мозгового вещества в дольках тимуса, которые в результате этого выглядят гомогенными.

Засвидетельствовано развитие дегенеративных изменений в печени по выраженному полиморфизму ядер гепатоцитов, в почках - по резкому цветовому контрасту между проксимальными и дистальными канальцами, в селезёнке - по увеличению количества апоптотических клеток и клеточного детрита, в легких - по утолщению межальвеолярных перегородок за счёт разрастания интерстициальной ткани.
При введении микродисперсной суспензии в дозе 500 мг/кг установлены умеренные сосудистые изменения в основном в почках, сердце, головном мозгу. В печени наблюдается расширение крупных портальных сосудов (рис. 3, б, 4, б). Установлены незначительные пролиферативные изменения в печени по единичным мелкоочаговым периваскулярным инфильтратам. Пролиферативные реакции лимфоидной ткани характеризуются признаками гипертрофии и пролиферации в селезёнке, о чем свидетельствуют расширение площади лимфоидных узелков, лимфатизация красной пульпы, появление большого количества бластных форм, лимфоидная инфильтрация в ткани внутренних органов: диффузная в пищеводе, желудке и очаговая - в печени, почках, переходе пищевода в желудок и в толстой кишке.

Выводы. Водная суспензия нанодисперсного диоксида кремния, синтезированного методом темплатирования, при однократном внутрижелудочном зондовом введении по критерию ЛД 50 относится к 3-му классу опасности (ЛД $50-4638$ мг/кг). Микродисперсный аналог относится к 4-му классу опасности. Гистологические изменения тканей внутренних органов и систем экспериментальных животных при однократном внутрижелудочном введении водной суспензии нанодисперсного диоксида кремния в дозе 500 мг/кг характеризуются выраженными модификациями системы кровообращения, проявляющимися значительным расширением и полнокровием крупных венозных сосудов печени, почек, тимуса, не обнаруженными при введении микродисперсного аналога. Установлена активация пролиферативных процессов в лимфоидной и макрофагальной системах, печени, почках, красной пульпе селезёнки, в то время как при введении микродисперсного аналога установлены лишь незначительные пролиферативные изменения в печени. Засвидетельствовано развитие дегенеративных изменений в печени по выраженному полиморфизму ядер гепатоцитов, в почках - по резкому цветовому контрасту между проксимальными и дистальными 
канальцами, в селезёнке - по увеличению количества апоптотических клеток и клеточного детрита, не установленных при введении микродисперсного аналога.

При внедрении нанодисперсного диоксида кремния, синтезированного методом темплатирования, имеющего мезопористое строение, в практическое использование для направленной доставки лекарств необходимо уточнение параметров хронической токсичности при пероральном поступлении. Для обеспечения безопасности персонала, который будет привлечен к процессу производства продукции, целесообразно уточнение параметров острой и хронической токсичности при ингаляционном поступлении.

\section{Список литературы}

1. Товкайло М. Нано в массы [Электронный ресурс] // Ведомости. - 2011. - № 40. - URL: http://www.vedomosti.ru (дата обращения: 18.01.2013).

2. Маркетинговый анализ рынков нанопродуктов. - М.: Техносфера, 2008. - 349 с.

3. Хамидулина Х.Х., Давыдова Ю.О. Международные подходы к оценке токсичности и опасности наночастиц и наноматериалов // Токсикологический вестник. - 2011. - № 6. - С. 53-57.

4. Donaldson K., Stone V. Current hypotheses on the mechanisms of toxicity of ultrafine particles // Ann Ist. Super Sanita. - 2003. - № 39 (3). - P. 405-410.

5. Elder A.C.P. The toxicology of nanomaterials. - Rochester, 2007. - 37 p.

6. Morgan D.L. NTP Toxicity Study Report on the atmospheric characterization, particle size, chemical composition, and workplace exposure assessment of cellulose insulation (CELLULOSEINS) // Toxic Rep Ser. - 2006. Vol. 74. - P. 1-62.

7. Токсиколого-гигеническая оценка безопасности нано- и микродисперсного оксида марганца (III, IY) / Н.В. Зайцева, М.А. Землянова, В.Н. Звездин, Е.В. Саенко, А.В. Тарантин, Р.Р. Махмудов, О.В. Лебединская, С.В. Мелехин, Т.И. Акафьева // Вопросы питания. - 2012. - Т. 81, № 5. - С. 13-19.

8. Meynen P., Cool E., Vansant F. Verified syntheses of mesoporous materials // Microporous and mesoporous materials. -2009 . - № 125. - P. 170-223

9. MP 1.2.2522-09. Методические рекомендации по выявлению наноматериалов, представляющих потенциальную опасность для здоровья человека [Электронный ресурс]. - URL: http://www.epidemiolog.ru/law/ san/?ELEMENT_ID=3240021 (дата обращения: 17.01.2013).

10. Magnetic hollow spheres of periodic mesoporous organosilica and $\mathrm{Fe}_{3} \mathrm{O}_{4}$ nanocrystals: fabrication and structure control / L. Zhang, S.Z. Qiao, Y.G. Jin, Z.G. Chen [et al.] // Advanced Materials. - 2008. - Vol. 20, is. 4. - P. 805-809.

11. Vallet-Regi M., Balas F., Arcos D. Mesoporous materials for drug delivery // Angew. Chem. Int. Ed. 2007. - № 46. - P. 7548-7558.

12. Нанонаука и нанотехнологии. Энциклопедия систем жизнеобеспечения / под ред. О. Авалелькарим, Чуньли Бай, С.П. Капица. - М.: МАГИСТР-ПРЕСС; ЮHЕСКО; EOLSS, 2009. - 1040 с.

13. Третьяков Ю.Д., Лукашин А.В., Елисеев А.А. Синтез функциональных нанокомпозитов на основе твердофазных нанореакторов // Успехи химии. - 2004. - Т. 73, № 9. - С. 974-998.

14. Stöber W., Fink A., Bohn E. Controlled growth of monodispersed spheres in the micron size range // J. Colloid and Interface Sci. - 1968. - Vol. 26. - P. 62-69.

15. The determination of pore volume and area distributions in porous substances. I. Computations from nitrogen isotherms / E.P. Barrett [et al.] // J. Am. Chem. Soc. - 1951. - Vol. 73. - P. 373-380.

\section{References}

1. Tovkaylo M. Nano v massy [Nanoproducts - mass production]. Vedomosti, 2011, no. 40. Available at: http://www.vedomosti.ru.

2. Marketingovyy analiz rynkov nanoproduktov [Marketing analysis of nanoproduct markets]. Moskva: Tekhnosfera, 2008. 349 p.

3. Khamidulina Kh.Kh., Davydova Yu.O. Mezhdunarodnye podkhody k otsenke toksichnosti i opasnosti nanochastits i nanomaterialov [International approaches to the assessment of the toxicity and hazards of nanoparticles and nanomaterials]. Toksikologicheskiy vestnik, 2011, no 6, pp. 53-57.

4. Donaldson K., Stone V. Current hypotheses on the mechanisms of toxicity of ultrafine particles. Ann Ist. Super Sanita., 2003, no 39 (3). pp. 405-410.

5. Elder A.C.P. The Toxicology of Nanomaterials. Rochester, 2007. 37 p.

6. Morgan D.L. NTP Toxicity Study Report on the atmospheric characteriza-tion, particle size, chemical composition, and workplace exposure assessment of cel-lulose insulation (CELLULOSEINS). Toxic Rep Ser., 2006, vol. 74, pp. 1-62.

7. Zaytseva N.V., Zemlyanova M.A., Zvezdin V.N., Saenko E.V., Tarantin A.V., Makhmudov R.R., Lebedinskaya O.V., Melekhin S.V., Akaf'eva T.I. Toksikologo-gigenicheskaya otsenka bezopasnosti nano- i mikrodis- 
persnogo oksida mar-gantsa (III, IY) [Hygienic and toxicological assessment of nano-and micro-dispersed manganese (III, IY) safety]. Voprosy pitaniya, 2012, vol. 81, no. 5, pp. 13-19.

8. Meynen P., Cool E., Vansant F. Verified syntheses of mesoporous materials. Microporous and mesoporous materials, 2009, no. 125, pp. 170-223.

9. MR 1.2.2522-09. Metodicheskie rekomendatsii po vyyavleniyu nanoma-terialov, predstavlyayushchikh potentsial'nuyu opasnost' dlya zdorov'ya cheloveka [Methodical guidelines for the identification of nanomaterials which pose a potential risk to human health]. Available at: http://www.epidemiolog.ru/law/san/?ELEMENT_ID=3240021.

10. Zhang L., Qiao S.Z., Jin Y.G., Chen Z.G. at al. Magnetic hollow spheres of periodic mesoporous organosilica and $\mathrm{Fe}_{3} \mathrm{O}_{4}$ Nanocrystals: fabrication and structure control. Advanced Materials, 2008, vol. 20, is. 4, pp. 805-809.

11. Vallet-Regi M., Balas F., Arcos D. Mesoporous materials for drug delivery. Angew. Chem. Int. Ed., 2007, no. 46 , pp. $7548-7558$.

12. Nanonauka i nanotekhnologii. Entsiklopediya sistem zhizneobespecheniya [Nanoscience and nanotechnology]. Ed. O. Avalel'karim, Chun'li Bay, S.P. Kapitsa. Moscow: MAGISTR-PRESS; YuNESKO; EOLSS, 2009. 1040 p.

13. Tret'yakov Yu.D., Lukashin A.V., Eliseev A.A. Sintez funktsional'nykh nanokompozitov na osnove tverdofaznykh nanoreaktorov [Synthesis of functional nanocomposites based on solid-phase nanoreactors]. Uspekhi khimii, 2004, vol. 73, no. 9, pp. 974-998.

14. Stöber W., Fink A., Bohn E. Controlled growth of monodispersed spheres in the micron size range. J. Colloid and Interface Sci., 1968, vol. 26, pp. 62-69.

15. Barrett E. P. et al. The determination of pore volume and area distributions in porous substances. I. Computations from nitrogen isotherms. J. Am. Chem. Soc., 1951, vol. 73, pp. 373-380.

\title{
TOXICOLOGICAL AND HYGIENIC SAFETY ASSESSMENT OF THE AQUEOUS SUSPENSION OF NANO-DISPERSED SILICON DIOXIDE, SYNTHESIZED USING LIQUID-CRYSTAL TEMPLATING
}

\author{
N.V. Zaitseva1, M.A. Zemlyanova1, V.N. Zvezdin'1, Ye.V. Sayenko² \\ ${ }^{1}$ Federal Scientific Center for Medical and Preventive Health Risk Management Technologies, \\ Russian Federation, 82 Monastyrskya St., Perm, 614045, \\ 2 Institute of Technical Chemistry, the Ural Branch of the Russian Academy of Sciences, Russian \\ Federation, 3 Academician Korolev St., Perm, 614045
}

An experimental study of the aqueous suspension of nano-dispersed silicon dioxide, which had been synthesized using liquid-crystal templating, by a single intra-gastric administration resulted in assigning the tested product to class of hazard 3 according to LD50. We identified a complex of morphological changes in the lowest tested dose of $500 \mathrm{mg} / \mathrm{kg}$ which manifested through pronounced changes in the circulatory system - a significant vasodilation and plethora of large blood vessels of the liver, kidneys and the thymus. We also observed the activation of proliferative processes in the lymphatic and macrophage system, the development of degenerative processes in the liver, the kidneys, the red pulp of the spleen and the lungs.

No death of the animals was observed when administering the micro-dispersed analog of the compound intra-gastrically (class of hazard 4). When administering $500 \mathrm{mg} / \mathrm{kg}$, we observed a complex of morphological changes - moderate vascular changes in the kidneys, the heart, the brain, and the liver, insignificant proliferative changes in the liver, a proliferative reaction in the lymphoid tissue, lymphocytic infiltration in the tissues of the oesophagus, the stomach, the liver, the kidneys and the large intestine.

Keywords: aqueous suspension of nano-dispersed silicon dioxide, potential hazard, toxicological and hygienic assessment, population health.

(C) Zaitseva N.V., Zemlyanova M.A., Zvezdin V.N., Sayenko Ye.V., 2013

Zaitseva Nina Vladimirovna - Fellow of the Russian Academy of Medical Sciences, DSc, Professor, Center Director (e-mail: znv@ fcrisk.ru, root@ fcrisk.ru, tel.: 8 (342) 237-25-34).

Zemlyanova Marina Aeksandrovna - DSc, Professor, Head of Department of Biochemical and Cytogenetic Diagnostics (e-mail: zem@fcrisk.ru, tel.: 8 (342) 236-39-30).

Zvezdin Vasiliy Nikolaevich - Research Fellow of Department of Biochemical and Cytogenetic Diagnostics (e-mail: zvezdin@fcrisk.ru, tel.: 8 (342) 237-18-15).

Saenko Ekaterina Vladimirovna - Ph.D., Research Fellow of Laboratory of Multiphase Dispersible Systems (e-mail: saenko_ekaterina@mail.ru, tel.: 8 (342) 237-82-80). 


\title{
АНАЛИТИЧЕСКИЕ ОБЗОРЫ
}

УДК 613.954: 612.4.09

\section{АНАЛИЗ КОРЕГУЛЯЦИИ ИММУННОЙ И НЕЙРОЭНДОКРИННОЙ СИСТЕМ В УСЛОВИЯХ ВОЗДЕЙСТВИЯ ФАКТОРОВ РИСКА}

\author{
Д.В. Ланин \\ Федеральный научный центр медико-профилактических технологий управления \\ рисками здоровью населения, Россия, 614045, г. Пермь, ул. Монастырская, 82
}

Проанализированы данные литературы о корегуляции иммунной и нейроэндокринной систем и ее изменении в условиях воздействия химических факторов. Обозначены подходы к выявлению маркеров эффекта для оценки риска развития дисфункции регуляторных систем в условиях воздействия различных факторов риска.

Ключевые слова: химические факторы, иммунная система, нейроэндокринная система.

В настоящее время общепризнанной является концепция о «триединой» регуляторной «метасистеме» $[2,9,15]$, в которую включается нейроэндокринный и иммунный контуры регуляции, при этом различные механизмы регуляции (нервный, эндокринный, иммунный) оказывают взаимные регулирующие влияния $[1,10,11,21,31]$. С другой стороны, хорошо известно о влиянии различных факторов риска, в том числе химических факторов окружающей и производственной среды, на отдельные контуры регуляции [5-7, 16, 24]. Данный обзор посвящен характеристике корегулирующих эффектов иммунной и нейроэндокринной систем и анализу работ, отражающих изменение отдельных звеньев регуляторной функции этих систем в условиях воздействия химических факторов риска.

Возможность нейроэндокринного влияния на функции иммунной системы хорошо известна. Еще в 80-х г. XX в. считалось, что глюкокортикоиды, андрогены, эстрогены и прогестерон подавляют иммунные реакции, а соматотропный гормон, тироксин и инсулин обладают стимулирующим эф- фектом. Однако уже на рубеже веков столь упрощенная схема находила все меньше сторонников, и в настоящее время доказано, что гормональные эффекты зависят от дозы, экспериментальной системы и ряда других факторов [12]. Таким образом, корректнее говорить не об иммуностимулирующем или иммуносупрессивном эффекте, а об иммуномодуляции в зависимости от дозы гормона, экспериментальной системы, а также типа клеток, компартамента иммунной системы и этапа иммунной реакции.

Наличие нейроэндокринных влияний на функции иммунной системы связано: с возможностью нервной системы прямо или косвенно контролировать секрецию различных гормонов, так же как и с наличием «обратного» влияния гормонов на нейромедиаторы, например, при стрессреакции $[17,18,46]$ или болевом синдроме [21]; с прямой симпатической [26] и парасимпатической иннервацией [38] лимфоидных тканей; с наличием на фагоцитирующих, иммунокомпетентных и вспомогательных клетках иммунной системы специфических рецепторов [31].

\section{(C) Ланин Д.В., 2013}

Ланин Дмитрий Владимирович - кандидат медицинских наук, доцент, старший научный сотрудник лаборатории методов клеточной диагностики (e-mail: dlan@mail.ru, тел./факс: 8 (342) 23-72-534). 
Разные исследователи описывают несколько регуляторных контуров. Одним из основных механизмов, при помощи которого осуществляется нейроэндокринная регуляция иммунной системы, является активация гипоталамо-гипофизарно-надпочечниковой оси [13]. На иммунную систему оказывают влияние все звенья этой регуляторной цепи, но основное внимание исследователи уделяют конечному звену - глюкокортикоидам [28], которые воздействуют на все звенья иммунной системы, и их эффекты трудно отнести однозначно либо к депрессивным, либо к стимулирующим [19, 49]. Скорее чем просто иммуносупрессивный, глюкокортикоиды оказывают иммуномодулирующий эффект, причем естественные и синтетические глюкокортикоиды порой оказывают противоположные эффекты [37]. Кроме того, необходимо помнить о наличии корегулирующих связей [42]. Так, например, доказано изменение направленности реакций иммунной системы в условиях введения глюкокортикоидов на фоне блокады $\beta$-адренорецепторов [17, 19, 44 .

При рассмотрении иммунотропных эффектов гипоталамо-гипофизарно-тиреоидной системы основное внимание уделяют анализу влияния тиреотропного гормона (ТТГ), а также тиреоидных гормонов (тироксина $\mathrm{T}_{4}$ и трийодтиронина - $\mathrm{T}_{3}$ ). Суммируя иммуномодулирующие эффекты ТТГ, можно сделать вывод о стимулирующей роли тиреотропного гормона [48]. При этом необходимо отметить, что наряду с прямыми эффектами ТТГ модулирует функции иммунной системы в основном через изменение продукции тиреоидных гормонов (прочие гипофизарные гормоны действуют на иммунную регуляцию также в основном через регуляцию выделения соответствующих гормонов). На сегодняшний день иммуномодулирующее действие тиреоидных гормонов широко известно. Доказано наличие иммуномодулирующего влияния тиреоидных гормонов на функции как адаптивного, так и врожденного иммунитета [3, 4, 12, 14, 35]. Важным аспектом проблемы также является взаимодействие гипоталамо-гипофизарно-надпочечниковой и гипоталамо-гипофизарно-тиреоидных осей, им- муномодурующие свойства которых часто диаметрально противоположны [27, 34].

Так же, как и гипоталамо-гипофизарнонадпочечниковая и гипоталамо-гипофизарно-тиреоидная оси, гипоталамо-гипофизарно-гонадная система модулирует иммунные функции [23]. Наиболее значимыми для регуляции иммунной системы считаются эстрогены. В общем физиологические концентрации эстрогенов усиливают иммунный ответ, тогда как физиологические концентрации андрогенов, таких как тестостерон и дегидроэпиандростерон, оказывают иммуносупрессивный эффект [22, 23]. Женский пол является фактором, увеличивающим риск развития многих системных аутоиммунных заболеваний, таких как системная красная волчанка, ревматоидный артрит и рассеянный склероз. При этом среди женщин эти заболевания встречаются (в зависимости от патологии) от двух до десяти раз чаще, чем у мужчин [39, 40]. Необходимо учитывать, что активность гипоталамогипофизарно-надпочечниковой оси ингибируется андрогенами и эстрогенами, таким образом, различное действие половых гормонов на гипоталамо-гипофизарно-надпочечниковую ось может определять половые различия в иммунных реакциях $[23,39]$.

Более подробный анализ нейроэндокринной регуляции функций иммунной системы с описанием молекулярных основ проведен нами ранее в работах $[12,13]$.

Таким образом, на сегодняшний момент представляется доказанным наличие нейроэндокринных регулирующих влияний на функции иммунной системы.

Кроме того, доказано участие в иммунных реакциях инсулина, пролактина, соматотропного гормона, симпатического и парасимпатического отделов вегетативной нервной системы и т.д. [25, 26, 30, 36, 38].

Однако не стоит забывать и о наличии обратного регулирующего влияния иммунной системы на нейроэндокринные механизмы через различные цитокины, а также выделении иммуноцитами соответствующих гормонов [35, 45]. Таким образом, мы можем говорить о двунаправленном регулирующем влиянии нейроэндокринной 
и иммунной систем. По мнению R.L. Wilder [50], схематически взаимодействие нервной, иммунной, эндокринной систем и их взаимосвязь с нарушениями психического и соматического здоровья могут быть показаны следующим образом (рис. 1).

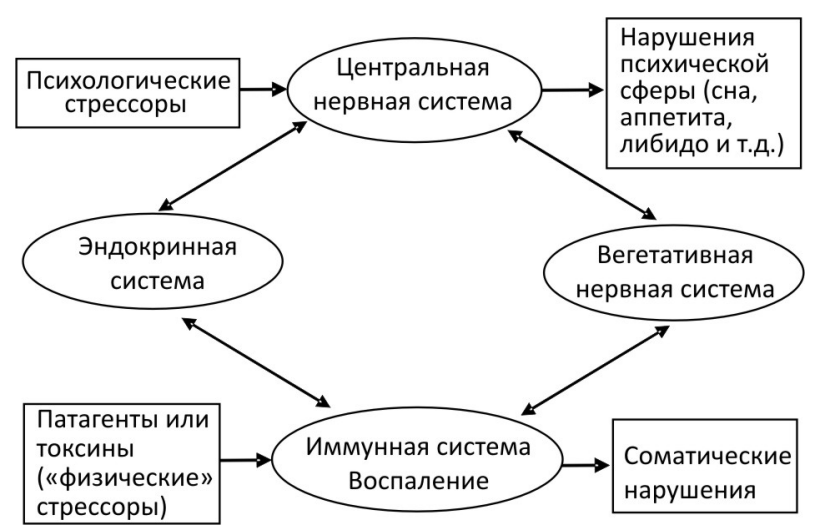

Рис. 1. Взаимодействие иммунной и нейроэндокринной систем (взято из [50] с изменениями)

Имеются многочисленные данные об изменениях в нейроэндокринном и иммунном статусе под влиянием различных химических факторов $[7,16,29]$. Так, в обзоре A.C. Gore [29] показано влияние хлорсодержащих органических веществ на нейроэндокринные функции, в частности, анализируется уровень клеток гипоталамуса, ответственных за выработку гонадотропинрелизинг гормона в условиях воздействия хлорсодержащих органических веществ. In vitro под влиянием этих веществ происходит повреждение экспрессии генов, снижение клеточной выживаемости и нарушение развития клеток, а также прямое токсическое воздействие на клеточные линии, в экспериментах in vivo продемонстрировано повреждение мРНК в соответствующих нейронах гипоталамуса у самок крыс. На основании этих данных автор делает вывод о наличии связи между нейроэндокринными осями, в частности гипоталамо-гипофизарно-гонадной, и экотоксикантами. В другом обзоре J. Janosek с соавт. [33] описывают эффекты влияния экзогенных ксенобиотиков на ядерные рецепторы и их сигнальные пути. Авторы высказывают мысль о наличии взаимосвязи между изменениями в мо- лекулярных механизмах действия гормонов, обусловленных экотоксикантами и иммуносупрессией, канцерогенезом, дисфункцией репродуктивной сферы и т.д. Имеются работы и по молекулярным механизмам токсикантиндуцированной иммуносупрессии [32]. В обзоре N.G. Pabello с соавт. представлены данные по взаимодействию нервной и иммунной систем в условиях экотоксикантной нагрузки, в частности, данные о влиянии на нейроиммунные сети тяжелых металлов и органических соединений [41]. Проведены многочисленные эпидемиологические исследования, которые показали связь роста числа заболеваний с влиянием химических факторов окружающей и производственной среды [7, $16,43]$. Во многих из этих исследований имеется указание на связь этих факторов с патологией нервной и эндокринной систем. Более того, некоторые химические вещества искусственного происхождения оказывают комплексное влияние на всю нейроэндокринную систему [47]. Также довольно хороший фактологический материал имеется и по влиянию внешнесредовых факторов на все звенья иммунного регуляционного контура. Так, например, доказаны способность $\mathrm{SO}_{2}$ и $\mathrm{NO}_{2}$ снижать фагоцитарную активность макрофагов (врождённый иммунитет) или нарушение пролиферации и созревания тимоцитов (адаптивный иммунитет) под воздействим диоксинов и ряда тяжелых металлов. Хорошо документирована связь аллергопатологии и загрязнения окружающей среды $[7,24]$.

Действие химических веществ на регуляторные системы возможно через следующие механизмы [8]:

1. Прямое воздействие химического соединения на соответствующую систему.

2. Действие метаболитов при биотрансформации в печени, коже, легких и т.д.

3. Опосредованное действие (активация перекисного окисления липидов, в том числе путем инактивации антиоксидантной системы; действие на соответствующие рецепторы с возможностью последующего влияния на генетический аппарат; инакти- 
вация ферментов; действие на клеточную мембрану и т.д.).

Академик В.А. Черешнев в своей работе [20] приводит схему влияния различных экологических воздействий на адаптивные системы организма с учетом концепции многоуровневой регуляции гомеостаза (рис. 2), которая также может быть использована для подтверждения наличия взаимодействия нервной, эндокринной и иммунной систем в реализации эффектов различных факторов риска. Опираясь на эту концепцию, можно предположить возможность детектирования маркеров воздействия и специфических, и неспецифических маркеров эффекта [16] не только для химических, но и для социальных или физических факторов.
Подводя итоги, можно сделать следующие заключения:

1. Представляется доказанным наличие иммунонейроэндокринной регуляторной сети.

2. Доказано воздействие техногенных химических факторов на отдельные звенья нервной, иммунной и эндокринной систем.

3. Возможно создание критериальной базы для диагностики дисрегуляторных изменений интегративных систем как маркеров влияния на здоровье техногенных химических и прочих факторов риска. Необходимо дальнейшее изучение темы комплексной оценки взаимодействия нервной, эндокринной и иммунной систем организма в условиях воздействия техногенного химического загрязнения.

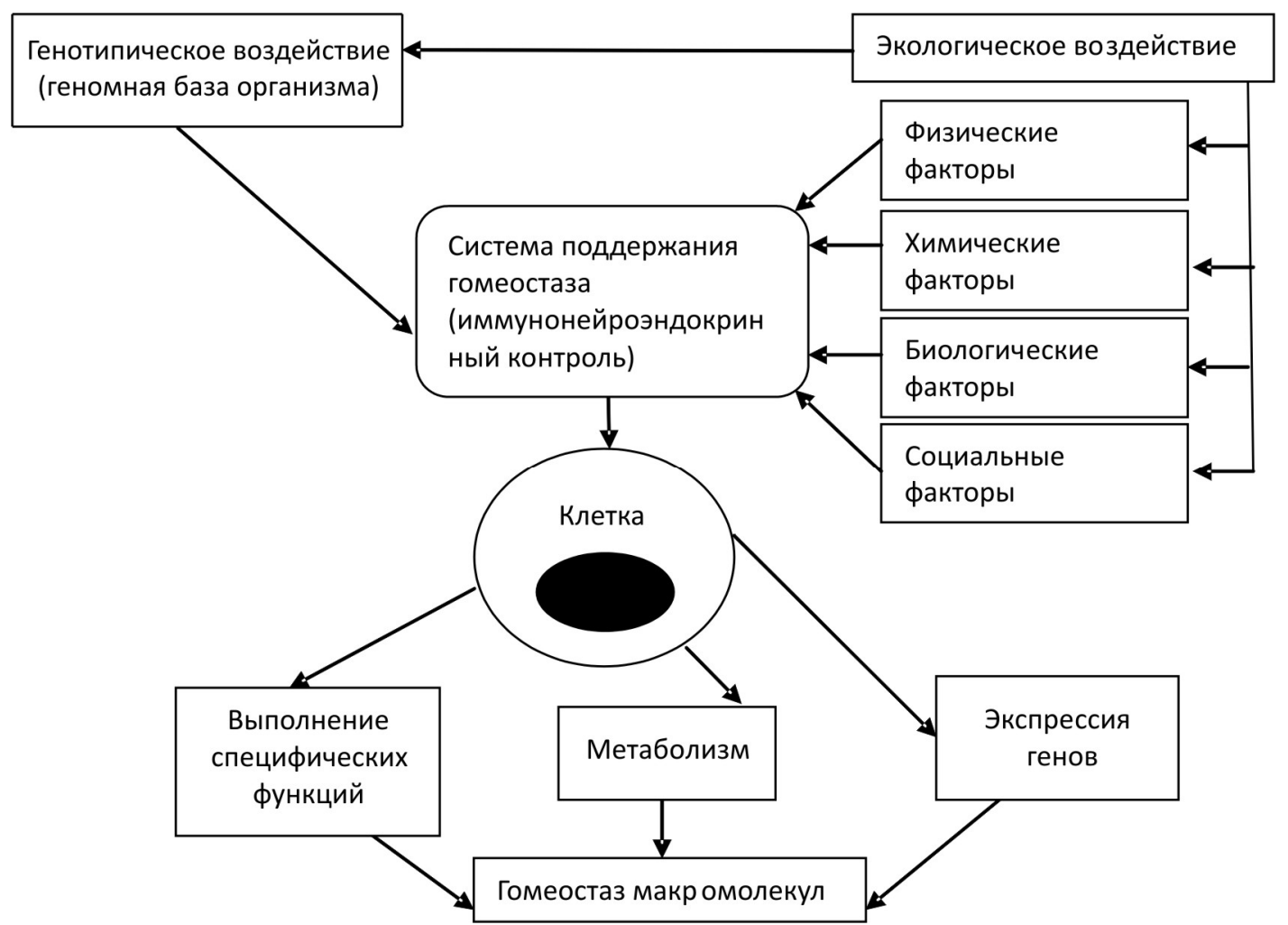

Рис. 2. Экологические воздействия и системы поддержания гомеостаза организма (взято из [20] с изменениями)

\section{Список литературы}

1. Абрамов В.В., Абрамова Т.Я. Асимметрия нервной, эндокринной и иммунной систем. - Новосибирск: Наука. Сибирская издательская фирма РАН, 1996. - 97 с.

2. Акмаев И.Г., Гриневич В.В. От нейроэндокринологии к нейроиммуноэндокринологии // Бюллетень экспериментальной биологии и медицины. - 2001. - Т. 131, № 1. - С. 22-32.

3. Бахметьев Б.А., Ширшев С.В., Красных М.С. Влияние тироксина на отдельные этапы иммуногенеза // Доклады Академии наук. - 2003. - Т. 390, № 5. - С. 706-708. 
4. Бахметьев Б.А., Ширшев С.В., Красных М.С. Некоторые молекулярные механизмы действия тироксина на фагоцитоз в системе in vivo и in vitro // Вестник Уральской медицинской академической науки. 2006. - № 3 (1). - C. 109-112.

5. Зайцева Н.В., Землянова М.А., Кирьянов Д.А. Оценка адаптационно-приспособительных реакций у детей в условиях хронического воздействия химических факторов // Экология человека. - 2005. - № 9. - С. 29-31.

6. Влияние на здоровье населения выбросов свинца автотранспортом / Н.В. Зайцева, Т.И. Тырыкина, М.А. Землянова, Т.С. Уланова // Гигиена и санитария. - 1999. - № 3. - С. 3-4.

7. Зайцева Н.В., Устинова О.Ю., Аминова А.И. Гигиенические аспекты нарушения здоровья детей при воздействии химических факторов среды обитания. - Пермь: Книжный формат, 2011. - 489 с.

8. Забродский П. Ф. Влияние ксенобиотиков на иммунный гомеостаз / под ред. Б. А. Курляндского, В.А. Филова // Общая токсикология. - М.: Медицина, 2002. - С. 352-384.

9. Корнева Е.А. Иммунофизиология - истоки и современные аспекты развития // Аллергия, астма и клиническая иммунология. - 2000. - №. 8. - С. 36-44.

10. Корнева Е.А., Клименко В.М., Шхинек Э.К. Нейрогуморальное обеспечение иммунного гомеостаза. Л.: Наука, 1978. - 176 с.

11. Корнева Е.А., Шхинек Э.К. Гормоны и иммунная система. - Л.: Наука, 1988. - 251 с.

12. Ланин Д.В., Зайцева Н.В., Долгих О.В. Нейроэндокринные механизмы регуляции функций иммунной системы // Успехи современной биологии. - 2011. - Т. 131, № 2. - С. 122-134.

13. Ланин Д.В., Зайцева Н.В., Долгих О.В. Молекулярные основы действия и иммуномодулирующие эффекты глюкокортикоидных гормонов // Иммунология. - 2010. - Т. 31, № 6. - С. 334-337.

14. Ланин Д.В., Шилов Ю.И., Ширшев С.В. Изменения функций фагоцитирующих клеток при экспериментальном тиреотоксикозе // Медицинская иммунология. - 2002. - Т. 4, № 2. - С. 125-126.

15. Полетаев А.Б., Морозов С.Г., Ковалев И.Е. Регуляторная метасистема (иммунонейроэндокринная регуляция гомеостаза). - М.: Медицина, 2002. - 168 с.

16. Онищенко Г.Г., Зайцева Н.В., Землянова М.А. Гигиеническая индикация последствий для здоровья при внешнесредовой экспозиции химических элементов. - Пермь: Книжный формат, 2011. - 489 с.

17. Влияние острого стресса и введения гидрокортизона в условиях блокады $\beta$-адренорецепторов на функции циркулирующего пула фагоцитирующих клеток / Ю.И. Шилов, Д.В. Ланин, Е.Г. Орлова, В.А. Черешнев // Вестник Уральской медицинской академической науки. - 2004. - № 2. - С. 71-77.

18. Роль адренергических механизмов в реализации иммуномодулирующих эффектов глюкокортикоидов при стрессе / Ю.И. Шилов, Е.Г. Орлова, Д.В. Ланин, С.Ю. Шилов // Вестник Уральской медицинской академической науки. - 2004. - № 4. - С. 87-93.

19. Шилов Ю.И., Ланин Д.В., Ширшев С.В. Влияние гидрокортизона на функции фагоцитирующих клеток периферической крови в условиях блокады $\beta$-адренорецепторов // Российский физиологический журнал им. И.М. Сеченова. - 2003. - Т. 89, № 5. - С. 543-550.

20. Черешнев В. А. Экология, иммунитет, здоровье [Электронный ресурс] // Известия Уральского государственного университета. - 2000. - № 16. - URL:http://proceedings.usu.ru/?base=mag/0016\%2803_092000\%29\&xsln=showArticle.xslt\&id=a19\&doc=../content.jsp (дата обращения 03.02.2013).

21. Chapman C.R., Tuckett R.P., Song C.W. Pain and stress in a systems perspective: Reciprocal neural, endocrine, and immune interactions // J. Pain. - 2008. - Vol. 9, № 2. - P. 122-145.

22. Cutolo M., Wilder R.L. Different roles for androgens and estrogens in the susceptibility to autoimmune rheumatic diseases // Rheum. Dis. Clin. North. Am. - 2000. - Vol. 26. - P. 825-839.

23. Immune sexual dimorphism: Effect of gonadal steroids on the expression of cytokines, sex steroid receptors, and lymphocyte proliferation / M.A. De León-Nava, K. Nava, G. Soldevila, L. Lopez-Griego, J.R. Chavez-Rios, J.A. Vargas-Villavicencio, J. Morales-Montor // J. Steroid Biochem. Mol. Biol. - 2009. - Vol. 113. - P. $57-64$.

24. Dietert R.R. Developmental immunotoxicology: Focus on health risks // Chem. Res. Toxicol. - 2009. Vol. 22. - P. 17-23.

25. Dorshkind E., Horseman N.D. The roles of prolactin, growth hormone, insulin-like growth factor-I, and thyroid hormones in lymphocyte development and function: insights from genetic models of hormone and hormone receptor deficiency // Endocrine Rev. - 2000. - Vol. 21. - P. 292-312.

26. The sympathetic nervean integrative interface between two supersystems: the brain and the immune system / I.J. Elenkov, R.L. Wilder, G.P. Chrousos, E.S. Vizi // Pharmacol. Rev. - 2000. - Vol. 52 (4). - P. $595-638$.

27. Eskandari F., Webster J.I., Sternberg E.M. Neural immune pathways and their connection to inflammatory diseases // Arthritis Res. Ther. - 2003. - Vol. 5 (6). - P. 251-256.

28. Franchimont D. Overview of the actions of glucocorticoids on the immune response: a good model to characterize new pathways of immunosuppression for new treatment strategies // Ann. N. Y. Acad. Sci. - 2004. Vol. 1024. - P. 124-137.

29. Gore A.C. Environmental toxicant effects on neuroendocrine function // Endocrine. - 2001. - Vol. 14. P. 235-246. 
30. Hattori N. Expression, regulation and biological actions of growth hormone (GH) and ghrelin in the immune system // Growth Hormone \& IGF Res. - 2009. - Vol. 19. - P. 187-197.

31. Heijnen C.J. Receptor regulation in neuroendocrine-immune communication: Current knowledge and future perspectives // Brain, Behav., and Immun. - 2007. - Vol. 21. - P. 1-8.

32. Holsapple M.P. Molecular mechanisms of toxicant-induced immunosuppression: role of second messengers // Annu. Rev. Pharmacol. - 1996 - Vol. 36. - P. 131-359.

33. Environmental xenobiotics and nuclear receptors: Interactions, effects and in vitro assessment / J. Janosek, K. Hilscherova, L. Blaha, I. Holoubek // Toxicol. in vitro - 2006. - Vol. 20. - P. 18-37.

34. Effects of short and long duration hypothyroidism and hyperthyroidism on the plasma adrenocorticotropin and corticosterone responses to ovine corticotropin-releasing hormone in rats / T.C. Kamilaris, C.R. De Bold, E.O. Johnson, E. Mamalaki, S.J. Listwak, A.E. Calogero, P.W. Gold, D.N. Orth // Endocrinol. - 1991. - Vol. 128. - P. $2567-2576$.

35. Klecha A.J., Genaro A.M., Lysionek A.E., Caro R.A., Coluccia A.G., Cremaschi G.A. Experimental evidence pointing to the bidirectional interaction between the immune system and the thyroid axis // Int. J. Immunopharmacol. - 2000. - Vol. 22. - P. 491-500.

36. Madden K.S. Catecholamines, sympathetic innervation, and immunity // Brain Behav. Immun. - 2003. Vol. 17, suppl. 1. - P. S5-S10.

37. The role of adrenocorticoids as modulators of immune function in health and disease: neural, endocrine and immune interactions / B.S. McEwen, C.A. Biron, K.W. Brunson, K. Bulloch, W.H. Chambers, F.S. Dhabhar, R.H. Goldfarb, R.P. Kitson, A.H. Miller, R.L. Spencer, J.M. Weiss // Brain Res. Rev. - 1997. - Vol. 23 (1-2). P. 79-133.

38. Mignini F., Streccioni V., Amenta F. Autonomic innervation of immune organs and neuroimmune modulation // Autonomic \& Autocoid Pharmacology. - 2003. - Vol. 23. - P. 1-25.

39. Nalbandian G., Kovats S. Understanding sex biases in immunity // Immunol. Res. - 2005. - Vol. 31 (2). P. 91-106.

40. Olsen N.J., Kovacs W.J. Hormones, pregnancy, and rheumatoid arthritis // J. Gend. Specif. Med. - 2002. Vol. 5. - P. 28-37.

41. Pabello N.G., Lawrence D.A. Neuroimmunotoxicology: Modulation of neuroimmune networks by toxicants // Clin. Neurosci. Res. - 2006. - Vol. 6. - P. 69-85.

42. Sapolsky R.M., Romero L.M., Munck A.U. How do glucocorticoids influence stress responses? Integrating permissive, suppressive, stimulatory, and preparative actions // Endocr. Rev. - 2000. - Vol. 21 (1). - P. 55-89.

43. Sattar S.A., Tetro J.A., Springthorpe V.S. Effects of environmental chemicals and the host-pathogen relationship: are there any negative consequences for human health? // Proceedings of the Symposium on New Biocides Development: The Combined Approach of Chemistry and Microbiology / ed. by P.C. Zhu. - Washington, DC: American Chemical Society, 2007. - P. 2-30.

44. Influence of beta-adrenergic receptor blockade on immunomodulatory effects of hydrocortisone / Ju.I. Shilov, D.V. Lanin, S.Ju. Shilov, E.G. Orlova // New Research on Immunology / ed. by Barbara A. Veskler. New York etc.: Nova Science Publishers, 2005. - P. 167-191.

45. Smith E.M. Neuropeptides as signal molecules in common with leukocytes and the hypothalamicpituitary-adrenal axis // Brain, Behavior, and Immunity. - 2008. - Vol. 22. - P. 3-14.

46. Tilbrook A.J., Clarke I.J. Neuroendocrine mechanisms of innate states of attenuated responsiveness of the hypothalamo-pituitary adrenal axis to stress // Frontiers in Neuroendocrinol. - 2006. - Vol. 27. - P. $285-307$.

47. Tilson H.A. Developmental neurotoxicology of endocrine disruptors and pesticides: identification of information gaps and research needs // Environmental health perspectives. - 1998. - Vol. 106, suppl 3. - P. 807-811.

48. Wang H.C., Klein J.R. Immune function of thyroid stimulating hormone and receptor // Crit. Rev. Immunol. - 2001. - Vol. 21. - P. 323-337.

49. Webster Marketon J.I., Glaser R. Stress hormones and immune function // Cell. Immunol. - 2008. - Vol. 252. P. 16-26.

50. Wilder R.L. Neuroendocrine-immune system interactions and autoimmunity // Annu. Rev. lmmunol. 1995. - Vol. 13. - P. 307-338.

\section{References}

1. Abramov V.V., Abramova T.Ya. Asimmetriya nervnoy, endokrinnoy i immunnoy system [The asymmetry of the nervous, endocrine and immune systems]. Novosibirsk: Nauka. Sibirskaya izdatel'skaya firma RAN, 1996. 97 p.

2. Akmaev I.G., Grinevich V.V. Ot neyroendokrinologii k neyroimmunoendokrinologii [From neuroendocrinology to neuro-immuno-endocrinology]. Byulleten' eksperimental'noy biologii $i$ meditsiny, 2001, vol. 131, no. 1 , pp. 22-32.

3. Bakhmet'ev B.A., Shirshev S.V., Krasnykh M.S. Vliyanie tiroksina na otdel'nye etapy immunogeneza [The effect of thyroxine on certain stages of immunogenesis]. Doklady Akademii Nauk, 2003, vol. 390, no. 5, pp. 706-708. 
4. Bakhmet'ev B.A., Shirshev S.V., Krasnykh M.S. Nekotorye molekulyarnye mekhanizmy deystviya tiroksina na fagotsitoz $\mathrm{v}$ sisteme in vivo i in vitro [Certain molecular mechanisms of action of thyroxine on the phagocytosis in in-vivo and in-vitro systems]. Vestnik Ural'skoy meditsinskoy akademicheskoy nauki, 2006, no. 3 (1), pp. 109-112.

5. Zaytseva N.V., Zemlyanova M.A., Kir'yanov D.A. Otsenka adaptatsionno-prisposobitel'nykh reaktsiy u detey $\mathrm{v}$ usloviyakh khronicheskogo vozdeystviya khimicheskikh faktorov [An assessment of adaptive responses in children chronically exposed to chemical factors]. Ekologiya cheloveka, 2005, no. 9, pp. 29-31.

6. Zaytseva N.V., Tyrykina T.I., Zemlyanova M.A., Ulanova T.S. Vliyanie na zdorov'e naseleniya vybrosov svintsa avtotransportom [The impact of lead emissions from motor vehicles on human health]. Gigiena i sanitariya, 1999, no. 3, pp. 3-4.

7. Zaytseva N.V., Ustinova O.Yu., Aminova A.I. Gigienicheskie aspekty narusheniya zdorov'ya detey pri vozdeystvii khimicheskikh faktorov sredy obitaniya [Hygienic aspects of health disorders in children exposed to chemical environmental factors]. Perm': Knizhnyy format, 2011. 489 p.

8. Zabrodskiy P.F. Vliyanie ksenobiotikov na immunnyy gomeostaz [The influence of xenobiotics on immune homeostasis]. Obshchaya toksikologiya. Moscow: Meditsina, 2002, pp. 352-384.

9. Korneva E.A. Immunofiziologiya - istoki i sovremennye aspekty razvitiya [Immunophysiology - the origins and modern aspects of development]. Allergiya, astma i klinicheskaya immunologiya, 2000, no. 8, pp. 36-44.

10. Korneva E.A., Klimenko V.M., Shkhinek E.K. Neyrogumoral'noe obespechenie immunnogo gomeostaza [Neurohumoral maintenance of immune homeostasis]. Leningrad: Nauka, 1978. 176 p.

11. Korneva E.A., Shkhinek E.K. Gormony i immunnaya sistema [Hormones and the immune system]. Leningrad: Nauka, 1988. $251 \mathrm{p}$.

12. Lanin D.V., Zaytseva N.V., Dolgikh O.V. Neyroendokrinnye mekhanizmy regulyatsii funktsiy immunnoy sistemy [Neuroendocrine mechanisms of the immune system regulation]. Uspekhi sovremennoy biologii, 2011 , vol. 131 , no. 2, pp. 122-134.

13. Lanin D.V., Zaytseva N.V., Dolgikh O.V. Molekulyarnye osnovy deystviya i immunomoduliruyushchie effekty glyukokortikoidnykh gormonov [The molecular basis of glucocorticoids' action and their immunomodulatory effects]. Immunologiya, 2010, vol. 31, no. 6, pp. 334-337.

14. Lanin D.V., Shilov Yu.I., Shirshev S.V. Izmeneniya funktsiy fagotsitiruyushchikh kletok pri eksperimental'nom tireotoksikoze [Changes in the function of phagocytic cells in experimental hyperthyroidism]. Meditsinskaya immunologiya, 2002, vol. 4, no. 2, pp. 125-126.

15. Poletaev A.B., Morozov S.G., Kovalev I.E. Regulyatornaya metasistema (immunoneyroendokrinnaya regulyatsiya gomeostaza) [Regulatory metasystem (immuno-endocrine regulation of homeostasis)]. Moscow: Meditsina, 2002. $168 \mathrm{p}$.

16. Onishchenko G.G., Zaytseva N.V., Zemlyanova M.A. Gigienicheskaya indikatsiya posledstviy dlya zdorov'ya pri vneshnesredovoy ekspozitsii khimicheskikh elementov [Hygienic indication of health effects from environmental exposure to chemical elements]. Perm': Knizhnyy format, 2011. 489 p.

17. Shilov Yu.I., Lanin D.V., Orlova E.G., Chereshnev V.A. Vliyanie ostrogo stressa i vvedeniya gidrokortizona $\mathrm{v}$ usloviyakh blokady $\beta$-adrenoretseptorov na funktsii tsirkuliruyushchego pula fagotsitiruyushchikh kletok [The effect of acute stress and the administration of hydrocortisone in $\beta$-adrenergic blockade on the function of the circulating pool of phagocytic cells]. Vestnik Ural'skoy meditsinskoy akademicheskoy nauki, 2004, no. 2, pp. 71-77.

18. Shilov Yu.I., Orlova E.G., Lanin D.V., Shilov S.Yu. Rol' adrenergicheskikh mekhanizmov v realizatsii immunomoduliruyushchikh effektov glyukokortikoidov pri stresse [The role of adrenergic mechanisms in the immunomodulatory effects of glucocorticoids in stress]. Vestnik Ural'skoy meditsinskoy akademicheskoy nauki, 2004, no 4, pp. 87-93.

19. Shilov Yu.I., Lanin D.V., Shirshev S.V. Vliyanie gidrokortizona na funktsii fagotsitiruyushchikh kletok perifericheskoy krovi v usloviyakh blokady $\beta$-adrenoretseptorov [The effect of hydrocortisone on the function of peripheral blood phagocytic cells in $\beta$-adrenoceptor blockade]. Rossiyskiy fiziologicheskiy zhurnal im. I.M. Sechenova, 2003, vol. 89 , no. 5, pp. 543-550.

20. Chereshnev V. A. Ekologiya, immunitet, zdorov'e [Ecology, immunity, health]. Izvestiya Ural'skogo gosudarstvennogo universiteta, 2000, no. 16, available at: http: //proceedings.usu.ru/? base=mag/0016\% 2803_09-2000\% $29 \& x \ln =$ showArticle.xslt\&id=a19\&doc=../content.jsp.

21. Chapman C.R., Tuckett R.P., Song C.W. Pain and stress in a systems perspective: Reciprocal neural, endocrine, and immune interactions. J. Pain, 2008, vol. 9, no. 2, pp. 122-145.

22. Cutolo M., Wilder R.L. Different roles for androgens and estrogens in the susceptibility to autoimmune rheumatic diseases. Rheum. Dis. Clin. North. Am., 2000, vol. 26, pp. 825-839.

23. De León-Nava M.A., Nava K., Soldevila G., Lopez-Griego L., Chavez-Rios J.R., Vargas-Villavicencio J.A., Morales-Montor J. Immune sexual dimorphism: Effect of gonadal steroids on the expression of cytokines, sex steroid receptors, and lymphocyte proliferation. J. Steroid Biochem. Mol. Biol, 2009, vol. 113, pp. 57-64.

24. Dietert R.R. Developmental immunotoxicology: Focus on health risks. Chem. Res. Toxicol, 2009, vol. 22, pp. 17-23. 
25. Dorshkind E., Horseman N. D. The roles of prolactin, growth hormone, insulin-like growth factor-I, and thyroid hormones in lymphocyte development and function: insights from genetic models of hormone and hormone receptor deficiency. Endocrine Rev., 2000, vol. 21, pp. 292-312.

26. Elenkov I.J., Wilder R.L., Chrousos G.P., Vizi E.S. The sympathetic nervean integrative interface between two supersystems: the brain and the immune system. Pharmacol. Rev., 2000, vol. 52 (4), pp. 595-638.

27. Eskandari F., Webster J.I., Sternberg E.M. Neural immune pathways and their connection to inflammatory diseases. Arthritis Res. Ther., 2003, vol. 5 (6), pp. 251-256.

28. Franchimont D. Overview of the actions of glucocorticoids on the immune response: a good model to characterize new pathways of immunosuppression for new treatment strategies. Ann. N. Y. Acad. Sci., 2004, vol. 1024, pp. $124-137$.

29. Gore A.C. Environmental toxicant effects on neuroendocrine function. Endocrine, 2001, vol. 14, pp. $235-246$.

30. Hattori N. Expression, regulation and biological actions of growth hormone (GH) and ghrelin in the immune system. Growth Hormone \& IGF Res., 2009, vol. 19, pp. 187-197.

31. Heijnen C.J. Receptor regulation in neuroendocrine-immune communication: Current knowledge and future perspectives. Brain, Behav., and Immun., 2007, vol. 21, pp. 1-8.

32. Holsapple M.P. Molecular mechanisms of toxicant-induced immunosuppression: role of second messengers. Annu. Rev. Pharmacol., 1996, vol. 36, pp. 131-359.

33. Janosek J., Hilscherova K., Blaha L., Holoubek I. Environmental xenobiotics and nuclear receptors: Interactions, effects and in vitro assessment. Toxicol. in vitro, 2006, vol. 20, P. 18-37.

34. Kamilaris T.C., De Bold C.R., Johnson E.O., Mamalaki E., Listwak S.J., Calogero A.E., Gold P.W., Orth D.N. Effects of short and long duration hypothyroidism and hyperthyroidism on the plasma adrenocorticotropin and corticosterone responses to ovine corticotropin-releasing hormone in rats. Endocrinol, 1991, vol. 128, pp. 2567-2576.

35. Klecha A.J., Genaro A.M., Lysionek A.E., Caro R.A., Coluccia A.G., Cremaschi G.A. Experimental evidence pointing to the bidirectional interaction between the immune system and the thyroid axis. Int. J. Immunopharmacol., 2000, vol. 22, pp. 491-500.

36. Madden K.S. Catecholamines, sympathetic innervation, and immunity. Brain Behav. Immun., 2003, vol. 17, suppl. 1, pp. S5-S10.

37. McEwen B.S., Biron C.A., Brunson K.W., Bulloch K., Chambers W.H., Dhabhar F.S., Goldfarb R.H., Kitson R.P., Miller A.H., Spencer R.L., Weiss J.M. The role of adrenocorticoids as modulators of immune function in health and disease: neural, endocrine and immune interactions. Brain Res. Rev., 1997, vol. 23 (1-2), pp. 79-133.

38. Mignini F., Streccioni V., Amenta F. Autonomic innervation of immune organs and neuroimmune modulation. Autonomic \& Autocoid Pharmacology, 2003, vol. 23, pp. 1-25.

39. Nalbandian G., Kovats S. Understanding sex biases in immunity. Immunol. Res., 2005, vol. 31 (2), pp. 91-106.

40. Olsen N.J., Kovacs W.J. Hormones, pregnancy, and rheumatoid arthritis. J. Gend. Specif. Med., 2002, vol. 5, pp. 28-37.

41. Pabello N.G., Lawrence D.A. Neuroimmunotoxicology: Modulation of neuroimmune networks by toxicants. Clin. Neurosci. Res., 2006, vol. 6, pp. 69-85.

42. Sapolsky R.M., Romero L.M., Munck A.U. How do glucocorticoids influence stress responses? Integrating permissive, suppressive, stimulatory, and preparative actions. Endocr. Rev., 2000, vol. 21 (1), pp. 55-89.

43. Sattar S.A., Tetro J.A., Springthorpe V.S. Effects of environmental chemicals and the host-pathogen relationship: are there any negative consequences for human health? Proceedings of the Symposium on New Biocides Development: The Combined Approach of Chemistry and Microbiology. Ed. by Zhu P.C. Washington, DC: American Chemical Society, 2007. Pp. 2-30.

44. Shilov Ju.I., Lanin D.V., Shilov S.Ju., Orlova E.G. Influence of beta-adrenergic receptor blockade on immunomodulatory effects of hydrocortisone. New Research on Immunology. Ed. by B.A. Veskler. New York etc.: Nova Science Publishers, 2005. Pp. 167-191.

45. Smith E.M. Neuropeptides as signal molecules in common with leukocytes and the hypothalamicpituitary-adrenal axis. Brain, Behavior, and Immunity, 2008, vol. 22, pp. 3-14.

46. Tilbrook A.J., Clarke I.J. Neuroendocrine mechanisms of innate states of attenuated responsiveness of the hypothalamo-pituitary adrenal axis to stress. Frontiers in Neuroendocrinol., 2006, vol. 27, pp. 285-307.

47. Tilson H.A. Developmental neurotoxicology of endocrine disruptors and pesticides: identification of information gaps and research needs. Environmental health perspectives, 1998, vol. 106, suppl. 3, pp. 807-811.

48. Wang H.C., Klein J.R. Immune function of thyroid stimulating hormone and receptor. Crit. Rev. Immunol., 2001, vol. 21, pp. 323-337.

49. Webster Marketon J.I., Glaser R. Stress hormones and immune function. Cell. Immunol., 2008, vol. 252, pp. 16-26.

50. Wilder R.L. Neuroendocrine-immune system interactions and autoimmunity. Annu. Rev. lmmunol., 1995, vol. 13, pp. 307-338. 


\section{THE ANALYSIS OF THE CO-REGULATION BETWEEN THE IMMUNE AND NEUROENDOCRINE SYSTEMS UNDER EXPOSURE TO RISK FACTORS}

\section{D.V. Lanin}

Federal Scientific Center for Medical and Preventive Health Risk Management Technologies, Russian Federation, 82 Monastyrskya St., Perm, 614045

This article analyzes data available in the literature on the co-regulation between the immune and neuroendocrine systems and its changes under exposure to chemical factors. We define the approaches to the identification of markers of effect to assess the risk of the dysfunction of the regulatory systems under exposure to various risk factors.

Keywords: chemical factors, immune system, neuroendocrine system.

C Lanin D.V., 2013

Lanin Dmitriy Vladimirovich - PhD, docent, senior research fellow of Immunogenetics Laboratory (e-mail: dlan@mail.ru, tel/fax: 8 (342) 23-72-534). 


\section{ПЕРЕЧЕНЬ ТРЕБОВАНИЙ И УСЛОВИЙ ДЛЯ ПУБЛИКАЦИИ СТАТЕЙ И ДРУГИХ МАТЕРИАЛОВ}

Для издания принимаются только ранее не опубликованные статьи и другие материалы, соответствующие тематике журнала.

1. РЕДАКЦИОННАЯ ЭТИКА. СТатья должна иметь визу руководителя и сопровождаться официальным направлением от учреждения, из которого выходит (с круглой печатью), в случаях, если рассматриваются вопросы, связанные с государственной тайной, - экспертным заключением о возможности публикации.

Статья должна быть подписана всеми авторами.

Все статьи проходят обязательное внешнее рецензирование и редактирование. Датой поступления статьи считается время подготовки ее окончательного (переработанного) варианта.

2. Плата с аспирантов за публикацию рукописей не взимается.

3. Бумажные материалы направляются в редакцию журнала почтой по адресу: 614045, г. Пермь, ул. Монастырская, 82. ФБУН «Федеральный научный центр медико-профилактических технологий управления рисками здоровью населения», с пометкой «В редакцию» или приносятся лично автором (авторами) по тому же адресу.

Материалы в электронном виде направляются в редакцию журнала по электронной почте по адресу journal@fcrisk.ru или передаются на электронных носителях (дисках, дискетах, USB-флэш-накопителях и т.д.) вместе с бумажной версией. Представление материалов в электронном виде является обязательным.

4. Статья должна быть напечатана в редакторе Microsoft Office Word:

- шрифт «Times New Roman»;

- основной текст - кегль 14;

- интервал - 1,5;

- поля: верхнее и нижнее - по 20 мм, слева - 20 мм, справа - 20 мм;

- отступ (абзац) - 1,25 см;

- нумерация страниц - по центру.

5. Объем статей - от 7 до 15 страниц (включая иллюстрации, таблицы и список литературы).

6. ТИТУЛЬНЫЙ лИСТ должен содержать:

1) УДК,

2) ФИО автора(ов),

3) полное наименование учреждения, в котором работает автор, в именительном падеже с обязательным указанием статуса организации (аббревиатура перед названием) и ведомственной принадлежности, а также места, где выполнялась работа (город, страна),

4) название статьи (заголовки и подзаголовки печатаются прописными буквами, жирным шрифтом и отделяются от основного текста пробелами),

5) аннотацию,

6) ключевые слова. Титульная часть должна быть напечатана шрифтом Arial.

Если авторов несколько, у каждой фамилии и соответствующего учреждения проставляется цифровой индекс. Если все авторы статьи работают в одном учреждении, указывать место работы каждого автора отдельно не нужно.

Вся титульная часть приводится как НА РУССКОМ, так и НА АНГЛИЙСКОМ ЯЗЫКАХ, транслитерированная в системе BSI (British Standard Institute (UK) \& ISI - Institute for Scientific Information (USA)). Фамилии авторов рекомендуется транслитерировать так же, как в предыдущих публикациях, или по системе BGN (Board of Geographic Names) - для транслитерации удобно использовать cайт http://www.translit.ru. В отношении организации(ий) важно, чтобы был указан официально принятый английский вариант наименования. 


\title{
Образец титульного листа:
}

УдК 616.036

\author{
М.И. Чубирко, Н.М Пичужкина, Л.А. Масайлова
}

Управление Федеральной службы по надзору в сфере защиты прав потребителей и благополучия человека по Воронежской области

2. Воронеж, Россия

\section{УПРАВЛЕНИЕ РИСКАМИ ЗДОРОВЬЮ НАСЕЛЕНИЯ В ПЕРИОД ЧРЕЗВЫЧАЙНОЙ СИТУАЦИИ}

\begin{abstract}
Аннотация. В условиях чрезвычайной ситуации, обусловленной пожарами, оценен риск для здоровья населения от острого воздействия химических веществ, загрязняющих атмоссрерный воздух. Представлены причинноследственные связи влияния загрязняющих веществ атмосферного воздуха и среднесуточной температуры на показатели смертности, госпитализации населения, в том числе по болезням системы кровообращения и органов дыхания. Показаны основные фракторы риска здоровью населения в период пожаров и мероприятия по инфоорированию населения.

Ключевые слова: чрезвычайная ситуация, пожары, загрязняющие вещества, температура, смертность, госпитализация, информирование.
\end{abstract}

\author{
M. Chubirko, N. Pizhuchkina, L. Masaylova \\ Voronezh Region Department of Federal Service on Customers' Rights Protection \\ and Human Well-Being Surveillance
}

Voronezh, Russia

\section{HEALTH RISK MANAGEMENT IN EMERGENCY SITUATIONS}

\begin{abstract}
In emergency situations caused by fires, we assessed health risks during acute exposure of the population to chemical air pollutants. We present cause-and-effect relations between air pollutant levels and average daily temperature, and death and hospital admission rates, including those for cardiovascular and respiratory diseases. The main health risk factors associated with fires and measures aimed at providing the population with information are discussed in this paper.
\end{abstract}

Keywords: emergency situation, fires, pollutants, temperature, death rate, hospital admission rates, information.

7. АВТОРСКОЕ РЕЗЮМЕ (аннотация). В аннотации должны быть изложены существенные факты работы. По ней читатель должен определить, стоит ли обращаться к полному тексту статьи для получения более подробной, интересующей его информации. Приветствуется структура аннотации, повторяющая структуру статьи: введение, цели и задачи, методы, результаты, заключение (выводы). Предмет, тема, цель работы указываются в том случае, если они не ясны из заглавия статьи; метод или методологию проведения работы целесообразно описывать в том случае, если они отличаются новизной или представляют интерес с точки зрения данной работы.

Объем текста авторского резюме определяется содержанием публикации (объемом сведений, их научной ценностью и/или практическим значением), но рекомендуемый объем составляет от 200 до 300 слов.

Резюме должно сопровождаться несколькими КЛЮЧЕВЫМИ СЛОВАМИ (от 3 до 6) или словосочетаниями через запятую, облегчающими классификацию работы в компьютерных поисковых системах.

8. ТЕКСТ СТАТЬИ. План построения оригинальных статей рекомендуется следующий: краткое введение, отражающее состояние вопроса к моменту написания статьи, цели и задачи исследования, материалы и методы, результаты и их обсуждение, выводы по пунктам или заключение, список цитированной литературы.

Изложение статьи должно быть ясным, сжатым, без длинных исторических введений и повторений.

Помимо общепринятых сокращений единиц измерения, физических, химических и математических величин и терминов (например, ДНК), допускаются аббревиатуры словосочетаний, часто повторяющихся в тексте. Все вводимые автором буквенные обозначения и аббревиатуры должны быть расшифрованы в тексте при их первом упоминании. Не допускаются сокращения простых слов, даже если они часто повторяются.

Дозы лекарственных средств, единицы измерения и другие численные величины должны быть указаны в системе СИ.

9. ТРЕБОВАНИЯ К РИСУНКАМ. Все графики, фотографии, диаграммы, схемы и другие виды иллюстративного материала (черно-белые или цветные рисунки высокого качества) следует размещать внутри тек- 
ста оригинала. Они должны читаться и быть четкими, их размеры не должны выходить за поля текстовой полосы. Иллюстративные материалы должны быть обозначены как рисунки и пронумерованы последовательно арабскими цифрами, каждый рисунок должен иметь название. Фотографии должны быть записаны в одном из форматов хранения растрового изображения (предпочтительно - TIFF, JPG, BMP). Редакция оставляет за собой право корректировать рисунки, не изменяя их содержания, с целью улучшения общего вида публикации. В тексте статьи обязательно делается ссылка на рисунок в круглых скобках с указанием его порядкового номера, например (рис. 1). Подписи к рисункам выполняются через одинарный интервал шрифтом Times New Roman, кегль - 10 и размещаются под рисунком. Подписи к рисункам не вставляются «в тело» рисунка.

10. ОФОРМЛЕНИЕ ТАБЛИЦ. Таблица по ширине и длине не должна выходить за рамки текстовой полосы. В тексте статьи обязательно делается ссылка на таблицу в круглых скобках с указанием ее порядкового номера, например (табл. 1). Сверху справа необходимо обозначить номер таблицы, ниже дается ее название. Сокращения слов в таблицах не допускаются. Все цифры в таблицах должны соответствовать цифрам в тексте и обязательно должны быть обработаны статистически. Каждая колонка таблицы должна иметь объясняющий заголовок с указанием, где необходимо, единиц измерения. Сноски и примечания к таблице надо размещать под таблицей. Следует избегать вертикально расположенных подписей. Таблицы не должны дублировать представленные в тексте и на рисунках результаты.

11. ФОРМУЛЫ располагаются по центру страницы и нумеруются последовательно арабскими цифрами в круглых скобках с правой стороны страницы. Во всех материалах рукописи должно соблюдаться единообразие разметки формул, символов. Необходимо унифицировать все используемые математические знаки и символы. Формулы, содержащие символы, отличные от стандартной раскладки английской и русской клавиатуры (греческие буквы, иероглифы и т.П., особенно используемые в надстрочных и подстрочных символах), должны быть представлены в виде рисунков, приложенных к статье. Однострочные формулы должны быть набраны тем же шрифтом, что и основной текст, к которому они относятся. Кегль многострочных формул должен быть снижен.

12. БИБЛИОГРАФИЧЕСКИЙ СПИСОК. Список литературы является обязательным. Ссылки на литературу нумеруются арабскими цифрами, которые в тексте должны быть заключены в квадратные скобки. Ссылка должна включать в себя: ФИО авторов; название статьи, журнала, книги; место издания; название издательства; год издания, номер тома и номера страниц, а также фамилии редакторов, составителей, переводчиков. Обратите внимание на то, что в пристатейных списках литературы надо указывать фамилии и инициалы всех авторов статьи, так как сокращение авторского коллектива до 2-3 фамилий влечет за собой потерю цитируемости у неназванных соавторов. Ссылки на издания приводятся на языке оригинала (на русском) в алфавитном порядке, затем - на иностранном. Отдельные работы одного и того же автора располагаются в соответствии с годом их публикации в порядке возрастания. Список литературы оформляется в соответствии с требованиями последнего ГОСТ Р 7.0.5-2008.

В оригинальных статьях допускается цитировать не более 30 источников, в обзорах литературы - не менее 50, но не более 100. Библиография может содержать основополагающие работы и публикации последних лет (желательно за последние 3-5 лет). Ссылки на неопубликованные работы не допускаются.

Автор несет ответственность за правильность библиографических данных.

13. СВЕДЕНИЯ ОБ АВТОРАХ. В обязательном порядке в конце статьи указываются сведения обо всех авторах, необходимые для обработки в Российском индексе научного цитирования:

1. Фамилия, имя и отчество всех авторов полностью.

2. Город, страна (в скобках).

3. Ученая степень.

4. Должность.

5. Полное название организации - места работы каждого автора.

6. Адрес (индекс, город, улица, дом, корпус и т.п.), адрес электронной почты, рабочий телефон (в скобках).

Пример:

Зайцева Нина Владимировна - академик РАМН, доктор медицинских наук, профессор; директор ФБУН «Федеральный научный центр медико-профилактических технологий управления рисками здоровью населения» (614045, г. Пермь, ул. Монастырская, 82; e-mail: znv@ fcrisk.ru, root@fcrisk.ru, тел.: 8 (342) 237-25-34).

Если все авторы работают в одном учреждении, можно не указывать место работы каждого автора отдельно, а написать корреспондентский почтовый адрес.

Не принимаются статьи, направленные в редакцию без выполнения требований настоящих условий публикации.

В случае отклонения статьи редакция направляет автору мотивированный отказ. 